\title{
Representaciones de los viajes de la Sagrada Familia en el arte de los siglos $\mathrm{V}-\mathrm{XV}^{*}$
}

\section{Representations of the Holy Family trips in the art of the 5th-15th centuries}

\author{
Patricia GRAU-DIECKMANN \\ Instituto Superior del Profesorado "Joaquín V. González", Buenos Aires \\ pgraud@uolsinectis.com.ar
}

Recibido: 28/10/2012

Aceptado: 08/12/2012

\begin{abstract}
Resumen: En el arte cristiano hay escenas en los ciclos de las vidas de la Virgen María y de Jesús que, aunque familiares y conocidas, poseen un contenido iconográfico que no responde estrictamente a los relatos evangélicos canónicos. Gestadas en el seno de la Iglesia, derivan también de leyendas e historias apócrifas y tradiciones orales. En este contexto, el presente trabajo analizará diferentes formas de representar los viajes de la Sagrada Familia durante el período abarcado entre los siglos V y XV, buscando una explicación a la popularidad de este tipo de escenas.
\end{abstract}

Palabras Clave: Huida a Egipto, Evangelios Apócrifos, Sagrada Familia, Viaje a Belén, arte cristiano.

\begin{abstract}
In Christian art there are scenes in the life cycles of the Virgin Mary and Jesus that, though familiar and known, possess an iconographic content that does not respond strictly to the canonical Gospel accounts. Engendered in the bosom of the Church, they also derived from apocryphal stories and legends and oral traditions. In this context, this paper will examine different ways of representing the Holy Family trips during the period between the $\mathrm{V}$ and $\mathrm{XV}$, seeking to explain the popularity of such scenes.
\end{abstract}

Keywords: Flight into Egypt, Apocrypha, Holy Family, Journey to Bethlehem, Christian art.

Sumario: 1. Introducción. 2. Los viajes. 2.1. Sus fuentes. 2.2 Tramas secundarias. 2.3. Consideraciones y relaciones. 3. Análisis de las obras. 3.1. Siglos V al X. 3.2. Período Románico. 3.3. Período Gótico. 3.4. El siglo XIV. 3.5. Los libros de horas. 3.6. Viajes posteriores al siglo XV. 4. Conclusión. Fuentes y Bibliografía

\section{Introducción}

(...) ¡Ah, más grande no fuera tener entre las manos la cabeza de Dios!

Delmira Agustini, Lo inefable

Los episodios de los viajes de la Sagrada Familia han excedido el marco del texto religioso sustentante para convertirse en hitos independientes de transmisión básicamente oral. Los relatos evangélicos originales quedaron relegados ante el enriquecimiento que significó su repetición de boca en boca como parte del conjunto 
anecdótico de la infancia de Jesús. En este contexto, San José, María y el Niño Jesús no son figuras para venerar, sino para reconocer y compadecer, pues se presentan como una familia excesivamente terrena. Las imágenes no muestran la gloria de Dios, sino su costado humano, se alejan de lo divino y permanecen en un ámbito en donde el drama humano podría ser, por única vez, más conmovedor que el drama de la pasión, la muerte y la resurrección de Cristo.

Por esa familiaridad con lo humano, por ese transitar por los caminos de escenarios reconocibles, las imágenes de los Viajes de la Sagrada Familia se transformaron en la estampa tradicional de peregrinaje en las que se reconoce que el Niño Jesús es el hijo de Dios hecho carne, pero también un ser sometido a los padecimientos humanos y cercano a la realidad cotidiana: es un infante que necesita consuelo, abrigo y protección. En la ilustración de los viajes, los fieles contemplaban al Dios verdaderamente hecho hombre, imaginaban los peligros y las angustias, acompañaban a la madre a punto de dar a luz, al niño perseguido, se condolían ante el correlato implícito de los pequeños inocentes masacrados por Herodes. Seguramente percibían que la perentoria fuga a Egipto era el testimonio de que Jesús no pudo sustraerse a los sufrimientos que aguardaban al mortal, a las incertidumbres y a las penurias. Era la evidencia de que compartió con los hombres su destino sobre la tierra.

En ese espacio plástico donde convergen ambas naturalezas de Jesús, los viajes son representados - tanto en su inalterabilidad como en su versatilidad - con una iconografía medular que se enriquece con atractivos inesperados. El análisis de obras producidas entre los siglos $\mathrm{V}$ y XV demuestra la existencia de variables que modifican, pero no alteran el núcleo temático inmutable (la familia y un animal de transporte), reiterando el motivo central con diferentes complementos y corroborando, así, las palabras de Umberto Eco: "la cultura medieval tiene el sentido de la innovación, pero se las ingenia para esconderlo bajo el disfraz de la repetición",

En este trabajo el criterio para la selección de obras responde al intento de abarcar distintos ámbitos geográficos, diversos soportes y medios plásticos, diferentes estilos y variadas interpretaciones iconográficas. La línea rectora es principalmente iconográfica e histórica, lo que resulta a menudo en desmedro del análisis propiamente plástico y estilístico.

Una innovación narrativa cristiana consistió en incorporar gente del pueblo a los relatos: campesinos, soldados, amas de casa, prostitutas, bandoleros, entre otros, conviven con el Dios encarnado. La religión se acercó al hombre común y éste, a su vez, le incorporó su patrimonio popular. Transformó a los antiguos dioses e inventó sus propios santos, rescató viejos santuarios y desarrolló su propio y sincrético culto,

*El presente artículo es una versión revisada y corregida de la versión inicial publicada en Cuestiones de Historia Medieval, Gerardo RodRÍGuEZ (dir.), Ediciones Selectus para Facultad de Filosofía y Letras, Universidad Católica Argentina, Buenos Aires, ISBN, vol.1: 978-987-26952-2-4, 2011, pp. 561/607. Se edita en Eikón / Imago por amable autorización de Gerardo Rodríguez. ${ }^{1}$ ECO, 1997: Ll. 
indudablemente marginal, pero a su vez legitimado por el uso. El hombre de pueblo tuvo su protagonismo en los relatos canónicos y apócrifos dentro de una religión humanizada que giraba en torno al sufrimiento del Dios hecho hombre. Las historias que enfatizan la naturaleza humana de Jesús — como los viajes de la Sagrada Familia - permiten al pueblo llano identificarse compasivamente con el hijo de un carpintero, con el hijo de Dios.

\section{Los viajes}

\subsection{Sus fuentes}

La Sagrada Familia realiza tres viajes relevantes: a Belén con María encinta; a Egipto, huyendo de la cólera de Herodes; y de regreso a Galilea, todos episodios plásticamente similares. El más frecuentemente representado fue el viaje a Egipto, probablemente por el atractivo dramatismo que generaba la situación. En ocasiones, el motivo de la huida está implícito en la plasmación de escenas correlativas, como la adoración de los magos, el sueño de José y la masacre de los Santos Inocentes, temas que la evocan y la complementan, infundiendo en el contemplador el recuerdo de esa atribulada familia que buscaba refugio en tierras lejanas.

Los relatos canónicos son sumamente concisos y poco descriptivos. Según Lucas 2, 1-5, José viaja de Nazaret a Belén con María embarazada para cumplir con el empadronamiento ordenado por César Augusto ${ }^{2}$. De acuerdo con Mateo 1, 13-15, una vez nacido Jesús, José recibe en sueños el aviso de un ángel de huir a Egipto porque

"Herodes buscará al niño para matarlo. (...) él, despertando, tomó de noche al niño y a su madre, y se fue a Egipto". Pocos versículos después, relata que "un ángel del Señor apareció en sueños a José en Egipto y le dijo: 'Levántate, toma al niño y a su madre, y vete a tierra de Israel, porque han muerto los que procuraban la muerte del niño.' Entonces él se levantó, tomó al niño y a su madre, y se fue a la tierra de Israel.” (Mt 1, 19-21).

\section{Los textos apócrifos}

Frente a lo escueto de esta narración, se deben buscar cuáles son las verdaderas fuentes de inspiración que determinaron la riqueza iconográfica desarrollada en las representaciones de los viajes de la Sagrada Familia. Los evangelios apócrifos y otras leyendas no admitidas en el canon son los que estimularán la creatividad plástica con su exuberancia imaginativa. Conocidas simultáneamente por la oralidad y por la lectura, estas repetidas y familiares historias eran transmitidas de generación en generación, sin que en general se tuviera la conciencia de que se trataba de

\footnotetext{
${ }^{2}$ En este trabajo no se analizará la compatibilidad histórica. Lo cierto es que sí existió un censo ordenado por Cirino, gobernador de Siria, en el año 6 d. C.
} 


\section{Patricia GRAU-DieCKMANN, Representaciones de los viajes de la Sagrada Familia}

narraciones no aprobadas por la Iglesia. $\mathrm{Si}$ bien el material canónico neotestamentario fue cerrado a fines del primer siglo, para ese entonces ya circulaban entre los cristianos otras colecciones preevangélicas (probablemente autónomas e independientes del material canónico), que, aisladamente o fusionadas con otros textos, dieron origen a los escritos apócrifos a partir del siglo II.

A finales del siglo V el papa Gelasio ${ }^{3}$ establece en su Decreto Gelasiano veintisiete obras de inspiración divina para el Nuevo Testamento. Las historias que quedaron fuera son lo que se conoce como textos apócrifos o pseudoepigráficos neotestamentarios. Esta condición no ha sido revertida hasta el día de hoy por ninguna de las Iglesias cristianas. Pese a ello, la iconografía que generaron no sólo fue tolerada, sino avalada por las autoridades eclesiásticas, según se desprende de su reproducción en emplazamientos sacros (iglesias, textos litúrgicos, etc.), y forman parte, tácitamente, del corpus iconográfico aceptado ${ }^{4}$.

Son entonces, los relatos extrabíblicos los que permiten conocer cómo se desarrollan los viajes de la familia, quiénes los acompañan, cuál es el itinerario, las ciudades donde hacen alto, las peripecias y los peligros que atraviesan.

Las principales fuentes, aunque no excluyentes, son los "Apócrifos de la Natividad"5 y los "Apócrifos de la Infancia". En ellos se narra que José y María no viajan solos a Belén, los acompaña un hijo de José ${ }^{7}$, fruto de un matrimonio anterior.

"Este hombre, José, se unió en santo matrimonio a una mujer que le dio hijos e hijas: cuatro varones y dos hembras, cuyos nombres eran: Judas y Josetos, Santiago y Simón; sus hijas se llamaban Lisia y Lidia"».

En Belén se refugian en una cueva para que María dé a luz. La partera Salomé llega cuando el Niño ha nacido, pero no cree en el nacimiento milagroso e insiste en intentar comprobar la virginidad intacta de María después del parto ${ }^{9}$. Su mano se seca en castigo por su incredulidad, pero su miembro recupera la vida cuando sostiene al Niño y reconoce en Él al Salvador.

Salomé los acompaña en la huida a Egipto: "Nos acompañaba también Salomé. Bajamos, pues, a Egipto (...)" ${ }^{\natural 0}$. Otros relatos hablan de una comitiva aún más

\footnotetext{
${ }^{3}$ Gobernó la Iglesia de 492 a 496.

${ }^{4}$ GRAU-DIECKMANN, 2008:20.

5 Protoevangelio de Santiago y Evangelio del Pseudo Mateo, los núcleos de ambos datan de la primera mitad del siglo II.

${ }^{6}$ Historia copta de José el carpintero (el núcleo griego de este evangelio puede remontarse hasta los siglos IV o V), Evangelio Armenio de la Infancia (del siglo VI) y Evangelio Árabe de la Infancia (del siglo VII).

${ }^{7}$ Es Jacobo o Santiago, supuesto autor del Protoevangelio de Santiago, en XVII, 2.

${ }^{8}$ Santiago/Jacobo, llamado también "el Menor" o "el Justo", y primer obispo de Jerusalén, podría ser el "hermano del Señor" que mencionan los evangelios tradicionales.

9 Este personaje es introducido en los textos para corroborar el nacimiento milagroso de Jesús:

"Virgo concepit, virgo peperit; post partum virgo permansit”. En RÉAU, T. 1, v. 2, 1996: 231.

${ }^{10}$ Historia copta de José el carpintero, VIII, 3.
} 
extensa: “(...) iban tres jóvenes haciendo el viaje con José y una muchacha con María"11, a los que se suman bueyes, caballos, asnos, ovejas, carneros y un séquito de leones, leopardos y lobos ${ }^{12}$.

El Evangelio del Pseudo Mateo es el que más detalles y anécdotas aporta a la huida. Uno de sus relatos generará una iconografía autónoma, la escena del Descanso durante la Huida a Egipto, popularizada a partir del siglo XV. En un alto, María desea unos dátiles que están demasiado altos para alcanzarlos. José, muy rudamente, niega su ayuda, pero Jesús ordena a la palmera que se incline hasta el piso para que su madre acceda a los frutos, y luego hace brotar de sus raíces agua clara y dulce. Unos ángeles plantarán una rama en el Paraíso y se convertirá en la palmera "reservada para todos los santos", almas cuando finalmente accedan junto al Señor.

Otra anécdota relatada por el Evangelio del Pseudo Mateo es la llegada de la familia a la ciudad egipcia de Sotina, en Hermópolis, donde había un templo con ídolos. Cuando María y el Niño entran a la ciudad, las estatuas caen al piso rompiéndose en pedazos. El gobernador Afrodisio y su séquito se presentan ante la familia para vengar el sacrilegio, pero, una vez frente a Jesús, reconoce que se encuentra ante un dios más poderoso que sus ídolos y termina adorándolo ${ }^{14}$.

En el mismo tenor, otro relato del Evangelio Armenio de la Infancia da cuenta de unas estatuas guardianas (las renombradas estatuas parlantes de Egipto), que gritan ante la presencia de enemigos, alertando sobre la presencia del Niño Dios: “¡He aquí que el hijo del gran rey ha entrado en el templo de Apolo!". El templo del dios y las estatuas se derrumban, y mueren cientos de personas, que luego serán resucitadas por Jesús, pero "otros ministros y arciprestes de Apolo, en número de ciento nueve no se levantaron"15. Finalmente, la Sagrada Familia encuentra acogida en casa de un príncipe hebreo, Eleazar, cuyos hijos eran Lázaro, Marta y María (Magdalena). Permanecen tres meses y en ese lapso se cimenta una fuerte relación entre Jesús y los tres niños de la casa ${ }^{16}$. Esta entrañable amistad infantil explica los lazos de cariño que los unirá, ya adultos, cuando se encuentren nuevamente en Judea.

Jacobus de Voragine (o Santiago de la Vorágine), recopilador dominico de historias sagradas y hagiografías, aporta en La Leyenda Dorada, de 1260, numerosos datos sobre los viajes de la Sagrada Familia y las historias relacionadas con los mismos. Debido a la enorme divulgación de este libro, su influencia en el arte será decisiva para decantar y seleccionar las escenas que perdurarán en la

\footnotetext{
${ }^{11}$ Evangelio del Pseudo Mateo, XVIII,1.

${ }^{12}$ Ibid., XIX, 1-2.

${ }^{13}$ Ibid., XX y XXI.

${ }^{14}$ Ibid., XXII al XXIV.

${ }^{15}$ Evangelio Armenio de la Infancia, XV, 11-21.

${ }^{16}$ Ibid., XV, 24-26.
} 


\section{Patricia GRAU-DieCKMAnN, Representaciones de los viajes de la Sagrada Familia}

iconografía cristiana. Vorágine sostiene que los años de afincamiento en Egipto fueron siete ${ }^{17}$.

\subsection{Tramas secundarias}

Existen algunas leyendas secundarias que son esporádicamente representadas en escenas colectivas relacionadas con la huida a Egipto, básicamente en el arte bizantino. Son las historias de dos niños que logran escapar a la matanza de los inocentes. Una es la de San Juan Bautista, que se oculta junto a su madre Santa Isabel dentro de una montaña que se abre para cobijarlos y luego se cierra con ellos adentro $^{18}$.

La otra historia, no narrada por ningún autor, sino transmitida oralmente, se refiere a cómo el futuro apóstol Natanael se salvó de morir bajo los soldados de Herodes. El origen de la leyenda es incierto, y probablemente se deba a la libre interpretación de un comentario de Juan Crisóstomo $(347-407)^{19}$ sobre el evangelio de San Juan. Éste narra que, de adulto, Natanael es guiado por Felipe hacia Jesús:

"Cuando vio Jesús que se acercaba Natanael, dijo de él: 'Ahí tenéis a un israelita de verdad, en quien no hay engaño'. Natanael le preguntó: ‘De qué me conoces?’ Respondió Jesús ‘Te vi cuando estabas debajo de la higuera, antes de que Felipe te llamara'",20.

Estas misteriosas palabras no son aclaradas en ninguna parte de los evangelios, pero Juan Crisóstomo, en sus Homilías sobre el Evangelio de San Juan, escribe: "Pero ¿quiere ello decir que el Señor vio a Natanael sólo cuando le llamó Felipe?"21. Esta simple frase, sin connotación explícita alguna, por algún motivo da origen a la leyenda de que la madre del apóstol había escondido a su hijo bajo una higuera para sustraerlo a la matanza de Herodes, y que Jesús alude a este hecho que todos, menos Natanael, ignoraban.

Una leyenda oral de fuente desconocida es la del campo de trigo ${ }^{22}$. Llegada a un campo de trigo que estaba siendo cosechado, la Sagrada Familia decide atravesarlo en su huida. Esa noche el trigo crece milagrosamente y tapa los rastros. A la mañana siguiente los soldados de Herodes preguntan por los fugitivos y un campesino les informa que habían pasado durante la siega. Los soldados, al ver el trigo maduro, renuncian a la persecución, creyendo que los viajeros habían pasado el año anterior.

\footnotetext{
${ }^{17}$ VoRAGINE, T.1:146. Nota: las traducciones al castellano de textos son de la autora, salvo otra indicación.

${ }^{18}$ Protoevangelio de Santiago y Evangelio Armenio de la Infancia.

${ }^{19}$ Patriarca de Constantinopla.

${ }^{20}$ Juan 1,45 ss.

${ }^{21}$ JUAN CRISÓSTOMO, 1991, Homilía XX, 3: 25.

${ }^{22}$ No figura en los evangelios apócrifos ni en La Leyenda Dorada. Réau (T.1, v.2:288) sugiere su fijación escrituraria en "un incunable del siglo XV o en un poema galés de fines del siglo XIII", pero no brinda más datos.
} 


\section{Patricia GRAU-DiECKMANN, Representaciones de los viajes de la Sagrada Familia}

Los apócrifos dan cuenta de numerosísimos personajes que se encuentran con la familia durante el trayecto, entre ellos una joven leprosa y un muchacho transformado en mulo por una hechicera. Ambos son curados milagrosamente y la historia termina en el enamoramiento entre ambos y en las bodas ${ }^{23}$.

Dos bandidos, Dimas y Gestas ${ }^{24}$, atacan a la familia para robarles y matarlos. Dimas, de mejor corazón, se compadece y los libera. Jesús vaticina que treinta años más tarde los tres serán crucificados juntos y que "el buen Ladrón” entrará con Él al Paraíso esa misma tarde.

También se relata que pañales, aguas de baño y efluvios del Niño obran milagros: curan locos, enfermos, y expulsan demonios. El Evangelio Árabe aclara, delicadamente, que los pañales habían sido previamente lavados. La Iglesia mantuvo una prudente actitud hacia esas singulares narraciones $\mathrm{y}$, si bien muchas otras historias apócrifas pasaron a formar parte de las representaciones gestadas en torno al ciclo de los viajes de la familia de Jesús, estas últimas historias de pañales, efluvios y bodas no pasaron de ser anécdotas curiosas.

\subsection{Consideraciones y relaciones}

Los motivos que aparecen en las narraciones analizadas se insertan en un contexto más amplio que merece ciertas aclaraciones. Generalmente la Sagrada Familia realiza los viajes a lomo de burro, bestia humilde por excelencia, ya que es el animal de los pobres ${ }^{25}$. Mientras el caballo es animal de guerra, el burro se utiliza para las actividades inofensivas, por lo que simboliza la paz y, como tal, es montado por Jesús cuando entra a Jerusalén como Príncipe de la Paz. La profecía mesiánica indicaba que el Ungido debía entrar a Jerusalén humildemente "(...) cabalgando sobre un asno, así sobre un pollino, hijo de asno" "26. Por otro lado, montar en asno era una de las formas simbólicas judías de aclamar a los reyes: "Y descendió Sadoc sacerdote y Nathán profeta (...) e hicieron subir a Salomón en la mula del rey David (...)"27. Vorágine dice que el burro fue llevado por José al empadronamiento de Belén en consideración al estado de preñez de María, y que el otro animal del pesebre, el buey, era para ser vendido para pagar el impuesto por el censo y los gastos del viaje ${ }^{28}$. Añade que seguramente la Virgen solventó los siete años de estadía en Egipto con el oro que le dieron los magos ${ }^{29}$.

La elección de Egipto como lugar de refugio ratifica la larga relación entre el pueblo escogido y el imperio egipcio. Abraham busca allí refugio y comida; José el hijo de Jacob, se convierte en consejero del faraón; de Egipto parte Moisés en busca

\footnotetext{
${ }^{23}$ Evangelio Árabe de la Infancia, XVII, XX, XXI y XX.

${ }^{24}$ Así los nombran el Evangelio de Nicodemo (recopilación tardía del siglo X) y La Leyenda Dorada. El Evangelio Árabe de la Infancia los menciona como Tito y Dumaco.

${ }^{25}$ Lo mismo se aplica para la mula.

${ }^{26} \mathrm{Zac}$ 9, 9.

${ }^{27} 1 \operatorname{Re} 1,38$.

${ }^{28}$ VORAGINE, 1995, T. I: 41.

${ }^{29}$ Ibid. : 146.
} 
de la tierra prometida; y Salomón aseguró políticamente su posición internacional casándose con la hija de un faraón de la XXI Dinastía. Mateo 2,15 recurre a una cita del Antiguo Testamento: "Yo llamé de Egipto a mi hijo"30, reafirmando esta conexión para indicar la tipología veterotestamentaria que señala que lo que sucedió con Jesús ya había sido prefigurado en la Biblia hebrea.

La distinción que se otorga a la palmera en el episodio de María y los dátiles, y su relación con los santos, es el origen de la iconografía que muestra a la palma como atributo de los que han sufrido martirio por la fe. Jesús entra a Jerusalén y los jerosolimitanos portan palmas como prefiguración de su Pasión. La importancia de la palma se mantiene: según algunas versiones, la cruz había sido fabricada con maderas de ciprés, cedro, olivo y palmera ${ }^{31}$. San Gabriel anuncia a María su inminente partida de la tierra en cuerpo y alma, y le dice: "María, levántate y toma esta palma que me ha dado el que plantó el paraíso. (...) muchos serán curados por su medio y servirá de prueba para todos los habitantes de Jerusalén" ${ }^{32}$. La palma identifica a los peregrinos medievales durante su piadoso deambular, asimilándolos así a la larga travesía de la Sagrada Familia. Los primeros peregrinos ingleses que viajaron a Jerusalén llevaban de regreso una palma como prueba de que habían estado en Tierra Santa, y por ello se les permitía portar simbólicamente una pequeña palma de plata ${ }^{33}$.

Las reiteradas menciones al culto de Apolo en Egipto permiten asumir que este dios representa a todos los dioses de la antigüedad suplantados por el cristianismo, al mismo tiempo que indican la perduración en el imaginario popular de ciertos mitos lejanos. Vorágine afirma que bajo Augusto se construyó un templo de paz, y que Apolo había vaticinado que el mismo duraría hasta que una virgen diera a luz un niño, por lo que se creyó que sería eterno. Sobre sus puertas colocaron la inscripción Templum Pacis Aeternum, pero la noche en que nació Jesús se derrumbó el templo y también cayeron estatuas paganas en otros lugares, cumpliéndose así la profecía de Jeremías 43, 12-13: "Y pondrá fuego a las casas de los dioses de Egipto; y los quemará y a ellos llevará cautivos (...) Además, quebrará las estatuas de Bethsemes, que es en tierra de Egipto, y las casas de los dioses de Egipto quemará a fuego" 34 .

\footnotetext{
${ }^{30}$ Oseas $11,1$.

${ }^{31}$ VORAGINE, 1995, T. I: 278.

32 Libro de Juan Arzobispo de Tesalónica, III, homilía compuesta por Juan I, arzobispo de Tesalónica (610-649). A lo largo de su relato, la palma es el "símbolo omnipresente como árbol de la vida" (SANTOS OTERO, 2002: 323). El mismo concepto se encuentra en VORAGINE, 1995, T. II, : 78.

${ }^{33}$ FOLEY, J., 1993.

${ }^{34}$ Isaías 46:2 también pronosticó la caída de los ídolos: "Esos dioses han caído en tierra, y todos se han hecho pedazos; no han podido salvar al que los llevaba."
} 


\section{Análisis de las obras}

\subsection{Siglos $\mathrm{V}$ al $\mathrm{X}$}

Santa María la Mayor en Roma: María emperatriz

Los programas iconográficos temprano-cristianos no incluían escenas sobre los viajes de la Sagrada Familia, porque las imágenes, básicamente simbólicas, reflejaban el querigma de salvación. Se representan escenas previas a la pasión de Cristo (prendimiento, juicio), milagros, Jesús entre los apóstoles, los primeros santos, orantes, el Buen Pastor y escenas del Antiguo Testamento. Es probable que los textos neotestamentarios (canónicos o apócrifos) no fueran tenidos en cuenta como relato, sino como mensaje, y, por lo tanto, generaron escasas imágenes testimoniales de la vida de Jesús.

A mediados del siglo IV se erige bajo el pontificado del papa Liberio (pontífice de 352 a 366) la iglesia de Santa María la Mayor (Fig. 1), una de las cuatro basílicas mayores de Roma ${ }^{35}$.

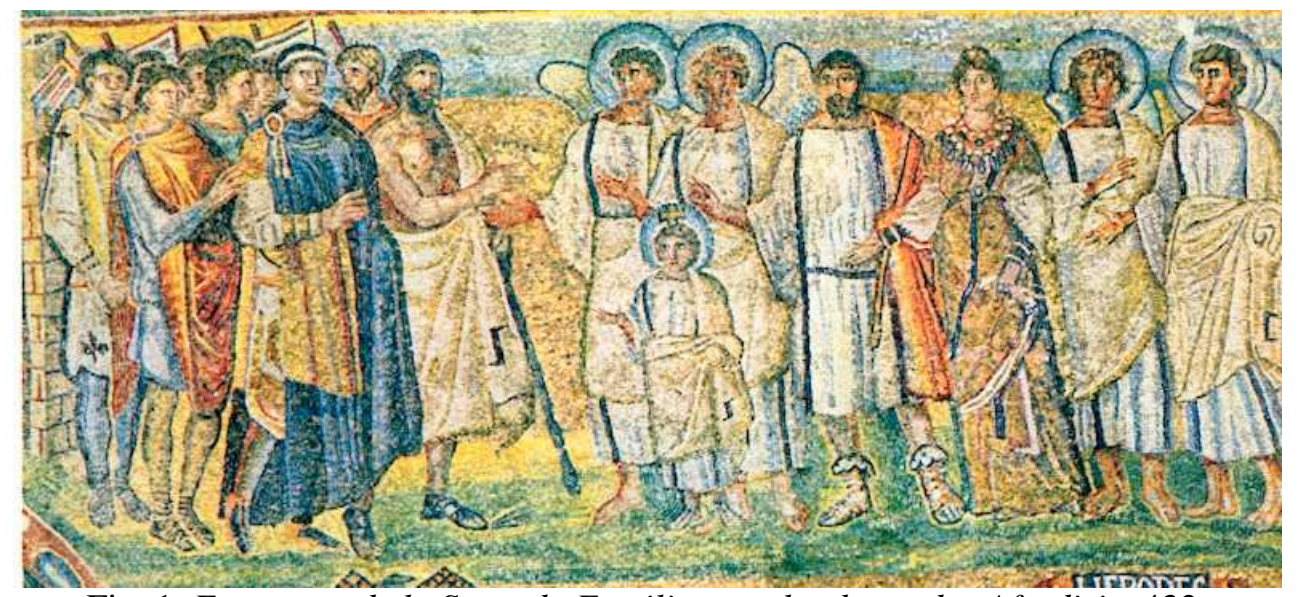

Fig. 1. Encuentro de la Sagrada Familia con el gobernador Afrodisio, 432, mosaico del arco triunfal de la Basílica de Santa María la Mayor, Roma, Italia. Foto tomada de Grabar, 1967, lámina 162.

En 432, bajo Sixto III, se ejecutaron en el arco de acceso al ábside de esta basílica unos deslumbrantes mosaicos que representan escenas de la vida de la Virgen. Las imágenes se distribuyen en tres registros horizontales, dispuestos a ambos lados del arco. En la clave se encuentra el trono vacío con un rollo sellado, que aguarda la segunda venida de Cristo, la Hetimasía ${ }^{36}$. En el registro superior están representadas la Anunciación, la Conversación de José con el Ángel, la Presentación en el Templo,

\footnotetext{
${ }^{35}$ Se encuentra sobre el monte Esquilino y es la iglesia occidental más antigua y de mayor tamaño dedicada a la Virgen María. La fachada actual fue construida en el siglo XVIII, pero en el interior permanecen intactos una serie de mosaicos con escenas del Antiguo y del Nuevo Testamento. Sus primeros mosaicos, realizados en las paredes de la nave en la segunda mitad del siglo IV, presentan las historias de Abraham, Isaac y Jacob, a la izquierda, y las de Moisés y Josué, a la derecha.

${ }^{36}$ Del gr. $\varepsilon \tau 0 \mu \alpha \phi \omega$, hetomafo, preparar.
} 


\section{Patricia GRAU-DiECKMANN, Representaciones de los viajes de la Sagrada Familia}

el Sueño de José. En el intermedio, la Adoración de los Magos, el Rey Afrodisio saluda a Cristo. En la parte inferior, la Masacre de los Inocentes, los Magos con Herodes. Curiosamente, la Natividad no es representada.

La prolífica construcción de templos como producto del Edicto de Milán, decretado por Constantino en 313, puso a disposición de la Iglesia grandes superficies a ser cubiertas con imágenes a escala monumental, que obligaban a ser contempladas e interpretadas a distancia. Los detalles debían ser evitados para no entorpecer una lectura clara. Las primitivas representaciones cristianas eran básicamente simbólicas y tendían a manifestar un mensaje salvífico, pero, al seleccionar escenas de la narración cristológica, el propósito se convierte en testimonial e histórico ${ }^{37}$.

Para poner fin a la disputa suscitada por el obispo Nestorio, que sostenía que había dos personas separadas en Cristo encarnado, y negaba a María como madre de su parte divina, el año anterior a la realización de los mosaicos de la basílica de Santa María la Mayor, el Concilio de Éfeso había declarado que María no sólo era madre de Cristo, sino madre de Dios: era la Theotokos ${ }^{38}$. La iconografía del ciclo mariano de Santa María Mayor es la reafirmación del dogma, la traslación a Roma de la omnisciente presencia doctrinaria del Concilio de Éfeso. María aparece en todas las escenas con las galas imperiales bizantinas y con ángeles custodios representados como los funcionarios que escoltaban a los emperadores. Sus vestimentas, joyas, atributos y porte resaltan su maternidad divina. A partir de este momento, la Virgen María cobrará cada vez mayor preponderancia en la devoción; será la Mater Dei, cuyo monograma es una letra M con una corona. José es aquí

\footnotetext{
${ }^{37}$ El carácter de los mosaicos de Santa María Mayor corresponde al del renacimiento postconstantiniano y es uno de los pocos ejemplos de arte tardorromano con influencia imperial bizantina. Hay un cambio de estilo con respecto a las pinturas de las catacumbas: el ilusionismo apenas esbozado - de carácter fantasmagórico ha desaparecido. El fondo es dorado y las figuras, hieráticas e inmóviles, están como recortadas contra el mismo. Esta escenificación de la historia sagrada se aleja del simbolismo estático de catacumbas y sarcófagos. El arte se encuentra aquí muy próximo del arte antiguo, las representaciones de vestimentas, rostros, paisajes y fenómenos atmosféricos recuerdan las imágenes de Pompeya. Se trata de un contenido cristiano bajo una vestimenta arcaica. Los colores son particularmente intensos y especialmente notables son los cielos con teselas de colores celestes, amarillos, ocres y verdes. Frecuentemente, el contorno de los personajes está constituido por anchos bordes y hay un intento de rudimentaria perspectiva aérea. Aquí se esbozan las tendencias del arte que florecerá en Ravena y en Bizancio. El mosaico remplazó a la técnica de la pintura mural catacumbaria. La utilización de piedras de colores para formar imágenes era conocida por los sumerios desde tres mil años antes de Cristo. Los romanos utilizaron teselas de mármol natural o coloreado — duras y resistentes, pero con un colorido acotado y más bien opaco - para decorar sus pavimentos. Los cristianos utilizaron los mosaicos parietales para crear una atmósfera religiosa que favorecía la anagogia. Emplearon brillantes vidrios coloreados, incluyendo la pintura de oro, lo que permitía una variedad de gamas e intensidades colorísticas imposibles de lograr con el mármol. La irregularidad de las caras de las teselas permitía que la luz reflejara de diferentes maneras, creando así un ambiente etéreo y fragmentado, que, sumado al resplandor del oro, conectaba el mundo celestial con el terreno.
}

${ }^{38}$ Del gr. $\theta \varepsilon 0 \varsigma$, Theos, Dios, y $\tau \iota \kappa \tau \omega$, tikto, dar a luz 
representado como un hombre relativamente joven, de cabello y barba oscuros. La tradición ha insistido en mostrar a José como un hombre mayor para no provocar suspicacia con respecto a la naturaleza de sus relaciones con María ${ }^{39}$. Una vez declarada Theotokos, la dignidad de María se enfatiza al ubicarla más allá de toda sospecha, aunque su marido estuviera notoriamente en edad de engendrar un hijo.

En el lado derecho del registro medio del arco de la mencionada basílica romana está representado el encuentro de la Sagrada Familia y su cortejo con el gobernador Afrodisio tras la caída de los ídolos:

"Entraron a una ciudad llamada Sotina y (...) fueron a cobijarse en un templo llamado el Capitolio de Egipto. En él había trescientos sesenta y cinco ídolos, a los que diariamente se tributaban honores sacrílegamente. (...) al entrar María con el Niño en el templo, todos los ídolos se vinieron a tierra, quedando deshechos y reducidos a pedazos.(...) Afrodisio, gobernador de aquella ciudad, vino al templo con todo su ejército (...) Pero (...) cuando entró al templo y vio que todos los ídolos yacían en el suelo boca abajo, se acercó a María, adoró al Niño (...) y se dirigió a su ejército y a sus amigos en estos términos: 'Si no fuera este Niño el Dios de nuestros dioses, éstos no hubieran sido derribados ni yacerían en tierra' $(. .),$.40 .

La destrucción de los ídolos por Dios había sido extensamente profetizada en el Antiguo Testamento: “(...) Jehová (...) acabará por completo con los ídolos” (Is. 2, $18)^{41}$.

La originalidad de los mosaicos de Santa María la Mayor estriba en que reflejan los relatos apócrifos cuando éstos aún no habían sido separados del canon ${ }^{42}$. De todo el relato del Pseudo Mateo, el único elemento que perdurará en la iconografía de la huida serán los ídolos que caen de sus pedestales, aunque aquí no hayan sido representados. Afrodisio no volverá a aparecer en las escenas.

\section{Iglesia de San Juan el Pequeño}

Durante los siglos VI y VII continúa la tendencia a representar esporádicamente los viajes de la familia de Jesús. Las escenas encontradas se hallan en el ámbito oriental. Es así que en Egipto, en las montañas cerca de la aldea de Deir-AbuHinnis, en uno de los hitos de la ruta que supuestamente transitó la familia en su huida, existen restos de un conglomerado de por lo menos 37 cuevas -algunas con grafitos cristianos-, que se extiende por más de dos kilómetros. Allí habitaban solitarios eremitas antes de la llegada del Islam. Cada monje vivía aisladamente,

\footnotetext{
${ }^{39}$ SCHAPIRO, 1987, : 9.

${ }^{40}$ Pseudo Mateo, caps. XXII-XXIV.

${ }^{41}$ También Is 19, 1; Is 21, 9; Jer 50, 2; Jer 51, 52; Ez 6, 6 y los ya citados Is 46, 2 y Jer 43, 12-13.

${ }^{42}$ El papa Dámaso (366-384) ya había intentado una primera separación.
} 
pero se congregaba con sus hermanos para el servicio divino en una iglesia excavada en la roca, hoy dedicada al eremita copto San Juan el Pequeño ${ }^{43}$. Las paredes están cubiertas con pinturas de esa época, realizadas por los mismos ermitaños en el siglo VI, de difícil visualización, pues se encuentran muy deterioradas. Especialmente los rostros han sido deliberadamente destruidos por oponentes al cristianismo. A pesar de ello, un mismo estilo es reconocible en todas las imágenes. Entre las representaciones se encuentran el aviso del ángel a José, Herodes ordenando la matanza y la huida a Egipto, que no presenta ningún detalle digno de ser destacado, salvo el hecho de que se sospecha que es el mural más antiguo que ilustra este tema en pintura, y que el ciclo es uno de los pocos de la época que se encuentran in situ.

\section{Tapas de un evangeliario}

En el último tercio del siglo VI o en el VII fueron talladas- probablemente en un taller constantinopolitano- las tapas de marfil de elefante del Evangeliario Etchmiadizin (Fig. 2). Los paneles, de 36,5 por $30,5 \mathrm{~cm}$, fueron llevados a Armenia, donde se los usó como cubierta para un evangeliario de 989 copiado en Noravank ${ }^{44}$.

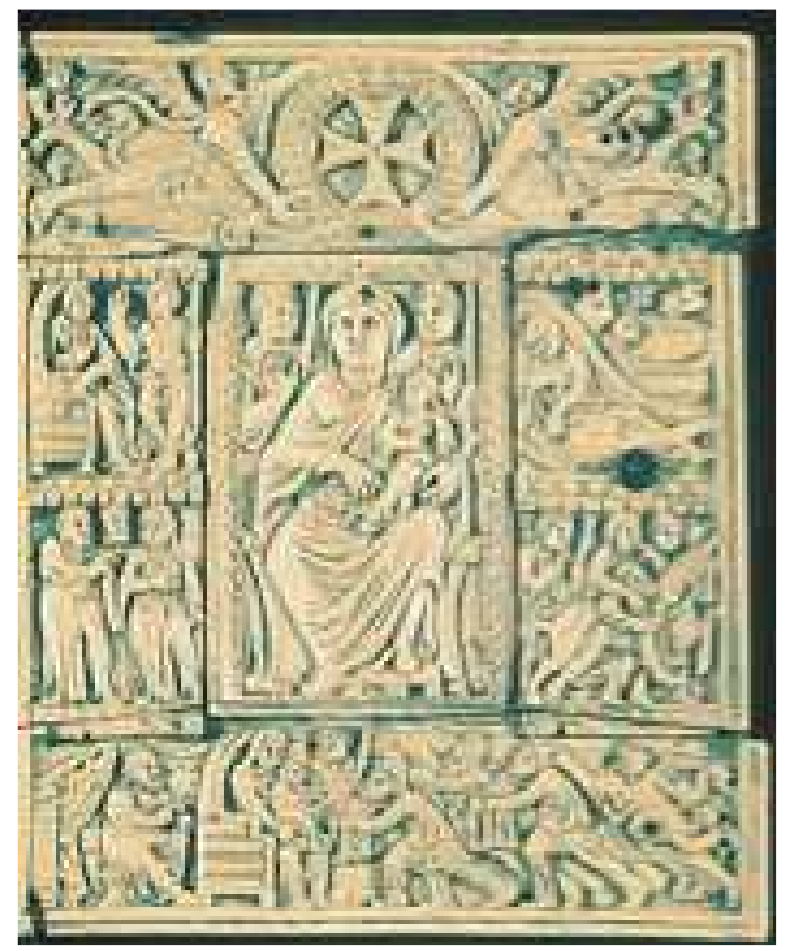

Fig. 2. Tapas de marfil del Evangeliario Etchmiadizin, siglos VI o VII, Cód. 2374, Biblioteca Mashtots Matenadaran, Erivan, Armenia. Foto tomada de http://armenianstudies.csufresno.edu/arts of armenia el 24/11/12

\footnotetext{
${ }^{43}$ No se incluyen imágenes pues son prácticamente irreconocibles.

${ }^{44}$ Cód. 2374, Biblioteca Mashtots Matenadaran, Erivan, Armenia. Cada placa está formada por cinco piezas de marfil encastradas entre sí mediante un sistema de filetes y ranuras. Los bordes externos presentan una moldura simple, mientras que los internos tienen diversos motivos decorativos, como losanges, palmetas e indentaciones.
} 


\section{Patricia GRAU-DiECKMANn, Representaciones de los viajes de la Sagrada Familia}

El panel central presenta a María entronizada con el Niño; a su alrededor se disponen: la placa superior, con dos ángeles sosteniendo la imago clipeata con una cruz maltesa; el lateral izquierdo, con la Visitación y María bebiendo el agua probática del Templo; el derecho, con la Natividad y el viaje a Belén ${ }^{45}$, y, en la placa inferior, la Epifanía.

El episodio del agua probática no existe en los textos canónicos, pero sí lo relata el Protoevangelio de Santiago $(16,1)$. A las mujeres sospechadas de infidelidad debía aplicárseles la ley mosaica, que prescribía que debían beber aguas amarguísimas maldecidas por el sacerdote ${ }^{46}$. Si enfermaban o morían, significaba que eran culpables. María sale airosa de la prueba.

En la placa correlativa opuesta se representa a María encinta, montada en el burro y custodiada por dos ángeles, presentados a la manera de los funcionarios de los dípticos romanos conmemorativos. Es una iconografía poco común, que muestra a la Virgen apoyándose en el hombro de José como alivio a su estado de gravidez. Aún se encuentran en camino, como lo indica la pata levantada del borrico. Los gestos y el rostro de José indican ternura y consideración hacia quien ha probado ser inocente mediante la peligrosa prueba de las aguas purgativas. En el contexto que muestra a María a punto de dar a luz, cobra sentido la inclusión del episodio del agua probática $\mathrm{y}$ viceversa, ya que ambas escenas son contestes y cada una justifica a la otra.

\section{Los frescos de Castelseprio: un viaje a Belén}

En la iglesia de Santa María Foris Portas de Castelseprio, Italia (Fig. 3), fueron descubiertos en 1944 unos frescos que aún despiertan polémicas irreconciliables acerca de su datación, que fluctúa entre el año 600 y el siglo $\mathrm{XIV}^{47}$.

\footnotetext{
${ }^{45}$ Erróneamente, muchos autores lo identifican como una Huida a Egipto, aunque claramente no lo es, ya que falta el Niño.

${ }^{46}$ Números 5, 11-28.

${ }^{47}$ HUBERT, 1968a, : 16; 1968b: 94/ss. Meyer Schapiro (SCHAPIRO, 1987: 111) desestima totalmente una datación tardía y ubica los frescos a fines del s. VIII o a principios del IX, y sostiene que seguramente se trate de la obra de un monje ortodoxo proveniente de la costa sirio-palestina helenizada, que huyó de los invasores musulmanes llevando consigo una cultura artística conservadora, imbuida de las tradiciones clásicas y formas orientales. El artista no era un recién llegado, sino que estaba afincado en Italia, pues es evidente que había asimilado elementos italianos y occidentales. La técnica que emplea es bizantina (distribución de pliegues y su realzado con líneas blancas, la expresión del burro y las formas de las alas de los ángeles), pero la elección de temas y la disposición de las escenas corresponden a usos netamente occidentales. Las imágenes se relacionan con las pinturas parietales catacumbarias paleocristianas en la delicadeza de las facciones y la forma de remarcarlas, así como en la expresión de los rostros y los colores empleados. Los rasgos de la Virgen hallan eco en los rostros pequeños —en los que se delinean nariz, ojos y boca (no así el óvalo de la cara) - de las figuras del Cementerio de los Santos Pedro y Marcelino y en las Catacumbas de Calixto, Roma (para las imágenes, ver GRABAR, 1967: 25, 30, 120, 212 y 213). También son similares los amplios ropajes de estilo tardorromano que envuelven a las figuras como bultos. Por otro lado, existen además semejanzas con los manuscritos carolingios de la Escuela de Ada (de raíces helenísticas), producidos por artistas entrenados en la tradición griega. Las inscripciones plantean otro enigma. Por una parte, las hay en griego pero escritas con letras trazadas
} 
El ciclo de los frescos de Castelseprio reproduce escenas de la infancia de Jesús, entre ellas el Viaje a Belén. El episodio sucede en una ciudad con edificios en el fondo y un recinto abierto en segundo plano, delimitado por arcadas y pilares, y la familia se encuentra en el primer plano. La escena, que muestra a la Virgen con la cabeza volteada hacía José, corresponde a la iconografía de la conversación que mantienen en torno a la visión de María sobre dos pueblos, uno que llora y otro que se regocija, y que representa la suerte de judíos y gentiles ${ }^{48}$.

El burro es guiado por Jacobo, el hijo de José, del que se divisan tan sólo una pierna y parte de su corta túnica. La expresión de María es inolvidable. La joven muestra el semblante de quien se encuentra en un difícil trance, alerta y atemorizada a la vez por la inminencia del parto. San José aparece con toda su ancianidad a cuestas, encorvado y entregado a la Providencia Divina. Sorprenden la naturalidad y el expresionismo de la pintura, que dan lugar a la percepción terrena de una situación netamente humana. Sólo el inmenso halo de María, remarcado, la ubica en un plano trascendente.

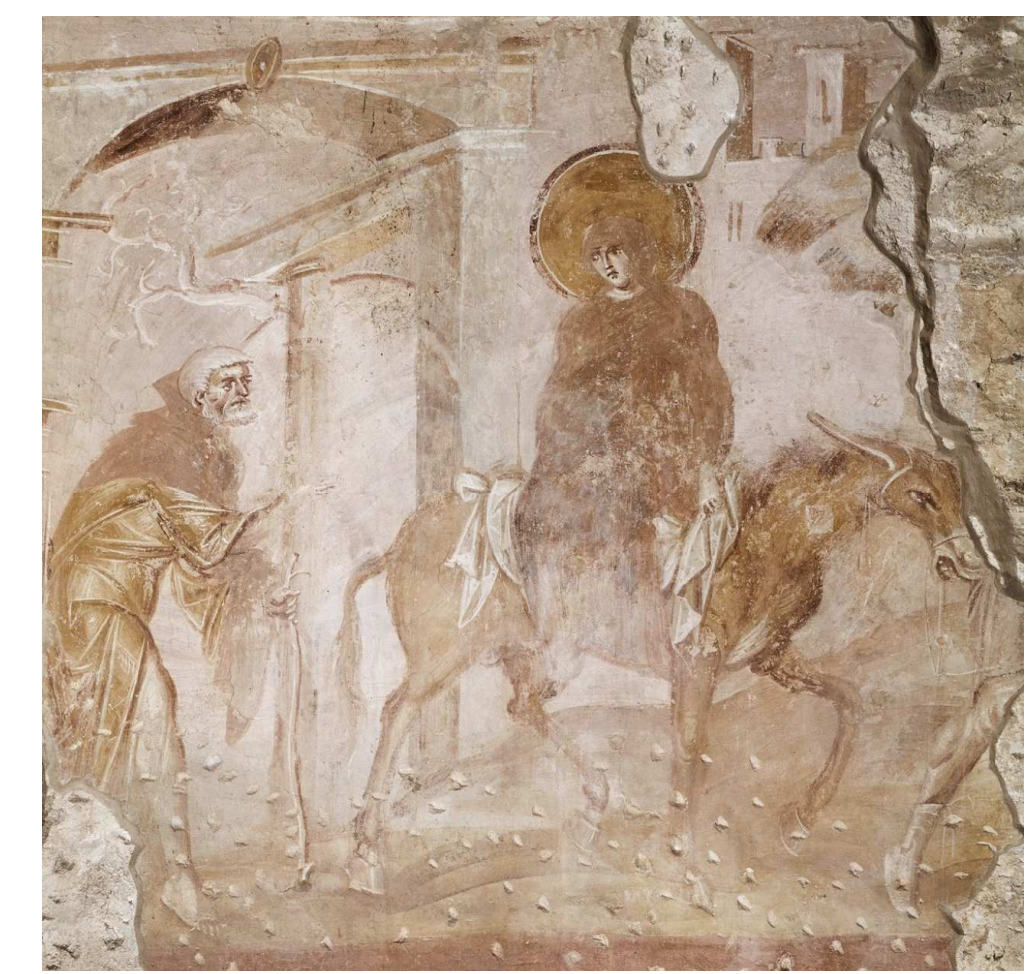

Fig. 3. Iglesia de Santa María Foris Portas, Castelseprio, Italia, fresco, datación imprecisa. Foto tomada de Hubert, 1968b, lámina 111.

defectuosamente. Por otro, sumando mayor confusión, junto a la pintura de la partera Salomé, está escrito "EMEA", una curiosa transcripción con caracteres latinos del sonido del artículo y del sustantivo griegos "H MAIA" (la partera). Probablemente estas leyendas en griego hayan sido escritas por una persona que no conocía el idioma, lo que contradice la teoría del artista sirio o copto.

${ }^{48}$ Protoevangelio de Santiago y Evangelio del Pseudo Mateo. 


\section{Patricia GRAU-DiECKMANn, Representaciones de los viajes de la Sagrada Familia}

\section{Bajo la advocación de San Patricio: la cruz Moone}

Mientras Europa continental era convulsionada por las oleadas de bárbaros que cambiaban la vieja y conocida fisonomía romanizada, en las Islas Británicas un mundo más antiguo, que había permanecido prácticamente aislado durante siglos, emergía nuevamente, reviviendo formas artísticas diferentes a las romanas. Cristianizados en 432 por San Patricio, los celtas de Irlanda sacaron a luz viejas formas estéticas de la cultura de La Tène para plasmar las nuevas imágenes religiosas. Ajenos a la representación antropomórfica mediterránea, concibieron un arte que refleja una enseñanza cristiana no romanizada, que amalgama símbolos cristianos con elementos celtas propios de los trabajadores del metal.

A partir de la introducción por San Patricio de las normas del monaquismo oriental, Irlanda desarrolló una Iglesia con características peculiares, con abades y monjes que emulaban la vida ascética de los cenobitas del desierto, en oposición al monacato occidental más universalista. Con el tiempo, Roma impuso la regla de San Benito, pero a costa de mantener un largo y enconado conflicto con los monjes.

En el condado de Kildare, cerca del monasterio de Castledermot, existe la más alta de las cruces en granito que los irlandeses situaban como hitos orientadores cerca de las torres cilíndricas de sus monasterios ${ }^{49}$. Es la cruz Moone ${ }^{50}$-del siglo VIII-, típica representante de las tradiciones del tallado en piedra con los entrelazados celtas característicos, y con un círculo en el cruce de los brazos ${ }^{51}$, antiguo símbolo que probablemente representara el sol $^{52}$. El pie está dividido en rectángulos con tallados planos y esquematizados de temas del Antiguo y del Nuevo

\footnotetext{
${ }^{49}$ Los monasterios irlandeses poseían unas torres redondas, edificios exentos que servían como albergue a los monjes y como escondite para los bienes de las iglesias (altares, reliquias, campanas, platerías) en momentos de peligro, y que funcionaban también como torres-vigía. Un documento sobre las viejas leyes de Irlanda indica que la torre redonda y su correspondiente iglesia celta de piedra debían construirse manteniendo ciertas proporciones: "la altura de la torre redonda agregada a la circunferencia de su base debe ser igual al perímetro externo de la iglesia de piedra" (Manuscrito No. 1336, col. 653, transcripto y traducido al irlandés en Corpus Iuris Hibernici, vol. Vi, pp. 2099.23 - 2100.10, Trinity College, Dublin). Alrededor de las torres existían unas muy altas cruces de granito - algunas sobrepasaban los tres metros de altura-, que señalaban los cuatro puntos cardinales. Marcaban los límites del lugar sagrado dentro del cual los fugitivos podían buscar refugio, servían como hitos en las procesiones y protegían a los monjes de las potencias infernales que los amenazaban.

${ }^{50}$ Mide 5,20 metros de altura. Presenta reminiscencias del arte de la orfebrería, con los brazos bordeados por una moldura que recuerda el trabajo en metal. Hay formas espiraladas, que evocan la serpiente enroscada, sin principio ni fin, alusión a lo eterno, a lo divino, a las fuerzas ctónicas. La espiral, como fuerza centrífuga, es un símbolo totalizador consagrado por la vieja religión, que se reitera una y otra vez para garantizar su eficiencia, reapareciendo en las cruces bajo una cubierta cristiana.

${ }^{51}$ Esta cruz celta se llama también cruz de Iona, en referencia al monasterio de Iona, fundado en el siglo VI por san Columba (521-597) en una isla en las costas de Escocia. Supuestamente el monasterio de Castledermont fue también fundado por Columba. En ese emplazamiento existe actualmente una iglesia franciscana del siglo XIII.

${ }^{52}$ SIMONS, 1966, pp. 70-71.
} 
Testamento. La cara oriental presenta a Daniel y siete leones, el sacrificio de Isaac, Adán y Eva, la Crucifixión, y varios animales; en la occidental están los doce apóstoles, otra Crucifixión y más animales; la norte presenta la multiplicación de los panes y los peces, la huida a Egipto, y los tres judíos salvados del fuego; la cara sur también muestra más animales.

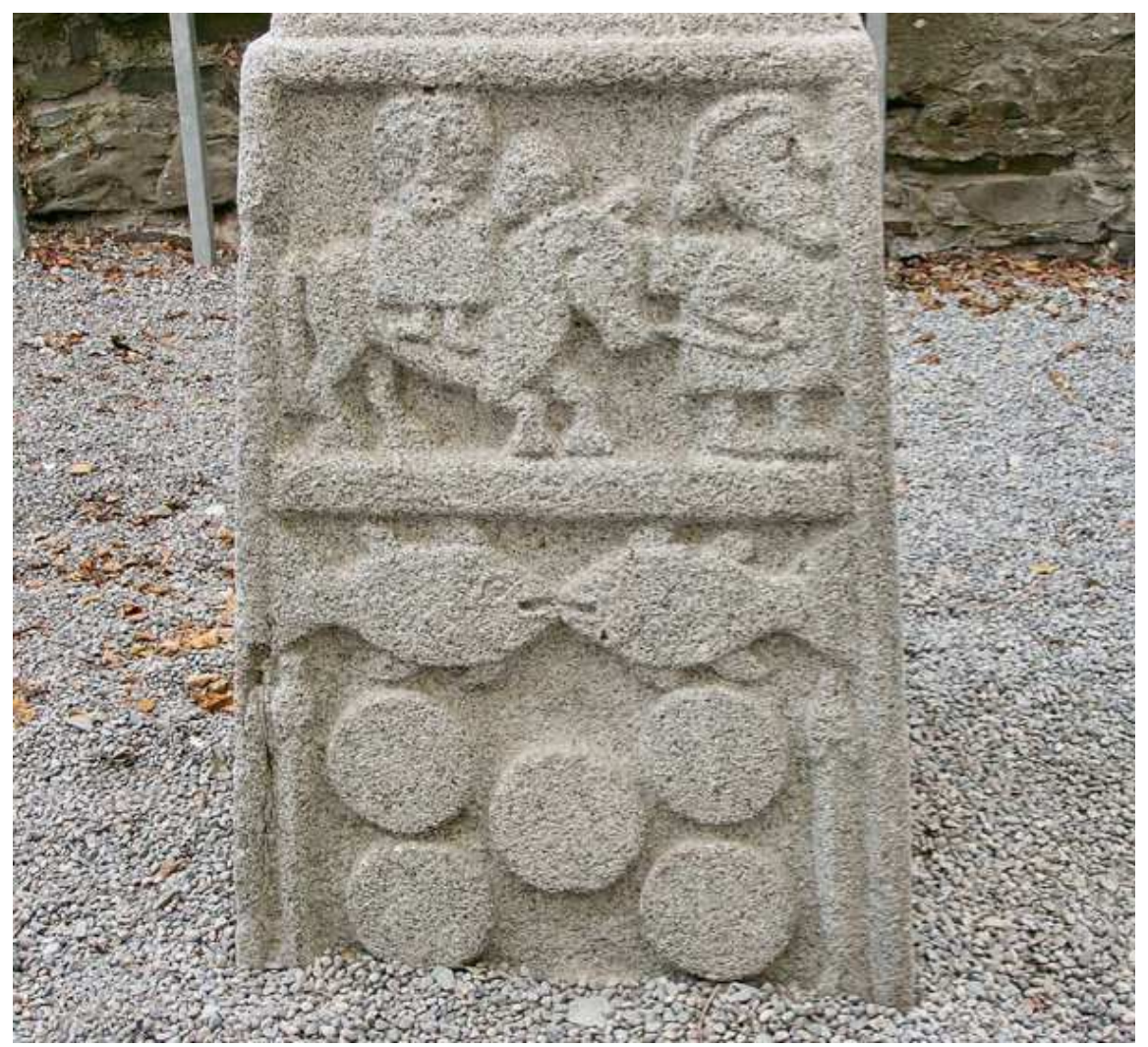

Fig. 4. Cruz Moone, siglo VIII, condado de Kildare, Irlanda, piedra.

Foto tomada de http://highcrosses.org/moone/ el 24/11/2012.

En el arte monástico de oriente, la fuga a Egipto se ilustraba alusivamente con el versículo 13 del salmo 91: "Sobre el león y el áspid pisarás; hollarás al cachorro del león y al dragón”, y también acompañaban la escena con numerosos animales salvajes. La pervivencia de los lazos de los monjes irlandeses con sus raíces cenobíticas originales se manifiesta en la perduración de una iconografía no conocida en occidente; de ahí las numerosas bestias que aparecen en ésta y en las otras cruces. La escena de la huida es frecuentemente representada en estas cruces, porque reflejaba una situación familiar y conmovedora para los monjes irlandeses, que debían partir a tierras lejanas para llevar la palabra de Dios. Consideraban que esta separación de sus familiares y de su país constituía una forma de peregrinaje penitencial que llamaban "martirio blanco"s3.

${ }^{53}$ Ibid., pp. 76-77. 


\section{Patricia GRAU-DiECKMANN, Representaciones de los viajes de la Sagrada Familia}

Al no existir en la tradición celta la figuración antropomorfa, los artistas recurrieron a esquemas geometrizados para adecuarse al novedoso temario cristiano. El cuerpo humano es representado como un cuadrado y las cabezas son círculos. Los brazos y las manos no siempre están presentes, y los pies están simplificados; la marcha se indica con éstos apuntando hacia el mismo lado. Si la figura está inmóvil, un pie apunta en cada dirección.

En el caso de la fuga de la cruz Moone (Fig. 4), la desmesurada silueta del rostro de José remite claramente a las máscaras funerarias celtas — con su protector de mejillas, que prolonga la barbilla, y su ala, que cubre la nuca-, como las que se encuentran en los enterramientos de Sutton Hoo, Norfolk, Gran Bretaña ${ }^{54}$. María, sin ningún atributo femenino, monta un caballo, en comparación, naturalista y bien definido en sus características. Esta excepción a la geometrización se debe a que la representación de animales era parte del legado artístico celta.

Lo que convierte a esta Huida en especialmente atractiva es la resignificación de un tópico proveniente de un ámbito - el Mediterráneo- en donde el tema básico era el hombre. Su traslado y la recreación en un territorio con tradiciones artísticas totalmente diferentes forzaron a los artistas a improvisar un nuevo lenguaje plástico y simbólico, que se adecuara a sus propias tradiciones, por un lado, y al nuevo temario, por otro.

\section{San Juan de Müstair, cantón de los Grisones}

Alrededor de 800 fue construida la iglesia del convento de San Juan de Müstair (Fig. 5), en el cantón de los Grisones, Suiza, por orden del propio Carlomagno. En su origen era una gran sala rectangular de unos dieciocho metros de ancho, pero con los siglos fue totalmente refaccionada y poco queda de la construcción carolingia. Allí se pintaron una serie de frescos con escenas del Antiguo y del Nuevo Testamento, dispuestos a lo largo de las paredes en cinco registros verticales, en paneles de 1,70 por $1,50 \mathrm{~m}$. Las pinturas, muy deterioradas y hasta pintadas por encima, han sido objeto de desgraciadas restauraciones ${ }^{55}$, lo que no permite apreciar fehacientemente la grandiosidad del más importante ciclo carolingio sobreviviente ${ }^{56}$.

En el estilo pictórico, la disposición de los personajes, sus ropajes y la arquitectura del fondo, de expresión mínima pero reveladora, se reconoce la factura de los artistas del norte de Italia, que, manteniendo las formas de las tradiciones antiguas, pintaron también en rojo, ocre y marrón los frescos de Santa María

\footnotetext{
${ }^{54}$ Otro ejemplo del uso de la máscara, en este caso frontal, es la representación de Mateo en el Libro de Durrow, en MEEHAN, 1996: 35. Imagen de una máscara de perfil disponible en Sutton Hoo Ship Burial: The Original Helmet (side view): http://www.archeurope.com/index.php?page=sutton-hoo-ship-burial-the-original-helmet-side-view, página consultada el 30/11/2012.

${ }_{55}$ Algunas han sido removidas al museo de Zurich, pero muchas se encuentran in situ, como la Huida a Egipto.

${ }^{56}$ BECKWITH, 1994: 24.
} 
Antigua, de la basílica inferior de San Vicente en Roma, y de San Vincenzo al Volturno en Molise.

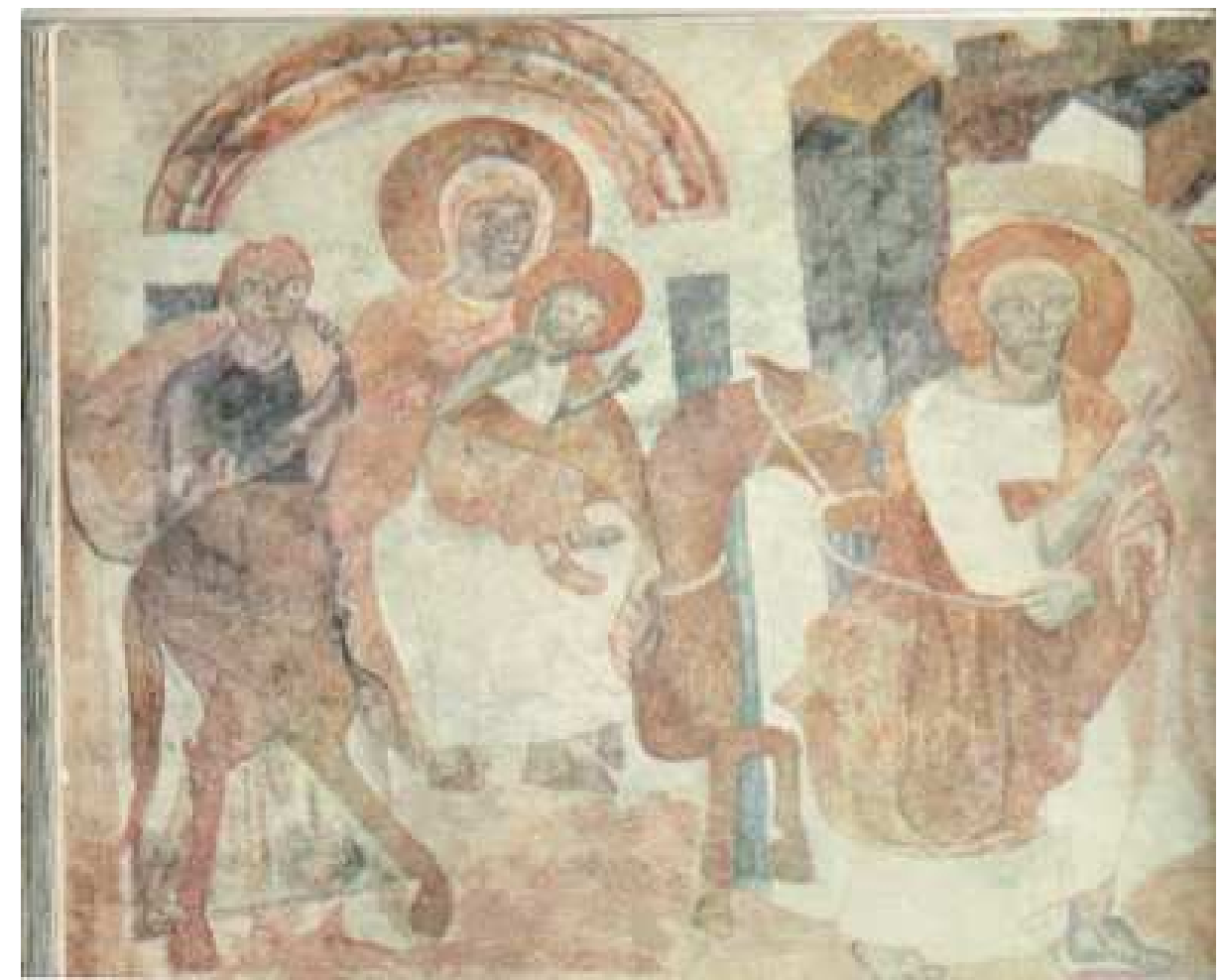

Fig. 5. Huida a Egipto, fresco, c. 800. Iglesia de San Juan de Müstair, cantón de los Grisones, Suiza, Foto tomada de Hubert, 1968b, lámina 164.

En la escena de la huida de la iglesia del convento de San Juan de Müstair, los personajes presentan amplios drapeados, típicos de esta escuela artística, y tienen piernas cortas y espaldas anchas. San José, que encabeza la marcha, lleva el manto al modo romano, enrollado en el brazo izquierdo, y con el hombro derecho al descubierto, y la cierra Jacobo, con larga túnica sin manto, y un gran saco al hombro.

Los ojos son proporcionalmente muy grandes y los gestos ampulosos y remarcados. José y el Niño realizan ambos el gesto de la oratio o bendición; pero curiosamente, mientras el primero lo realiza con los dedos índice y medio, Jesús extiende sólo un dedo, en una confusa representación de lo que parecería ser el pulgar, contradiciendo la iconografía aceptada. José tiene un protagonismo inusual (en oposición a su papel tradicionalmente pasivo e insignificante), reforzado por su halo y un arco que lo encuadra ${ }^{57}$. Es un hombre mayor pero lleno de energía, que guía a la mula e, indiscutidamente, está a cargo de la expedición. Paradójicamente,

\footnotetext{
${ }^{57}$ Tan tardíamente como en el siglo XV el papa franciscano Sixto IV convirtió a José en "gemma mundi, nutritor Domini", estableciendo su festividad el 19 de marzo.
} 


\section{Patricia GRAU-DiECKMANN, Representaciones de los viajes de la Sagrada Familia}

en la escena convergen una sensación de hieratismo y de desplazamiento al mismo tiempo.

Pese al estatismo de los personajes, el artista ha sabido dotarlos de un sentido de urgencia y marcha, que indica la prisa con que huyen. Este sentido de movimiento está insinuado por el paso del animal y la posición de los pies de José. El escenario es en las afueras de una ciudad, con sus murallas vistas desde el exterior y con edificios adosados a éstas. Los arcos de acceso a la misma son aprovechados para enmarcar y realzar a los miembros de la Sagrada Familia. En este fresco, la Virgen y el Niño están enmarcados por dos columnas que sostienen una arcada que los destaca y, adicionalmente, la propia María funciona como trono del Niño, que se sienta sobre ella, destacando doblemente la mímesis de la iconografía imperial. Desde el momento en que los primeros conversos eligen las imágenes como medio para transmitir los postulados cristianos, les fue necesario recurrir a modelos familiares que mejor pudieran expresar la grandeza, la dignidad y la majestad de Dios. Los ejemplos fueron tomados del mundo romano, el ámbito público icónicamente determinable e identificable. El emperador en majestad, presentado frontalmente en un trono con subpedáneo, bajo un ábside o arco que enfatiza su potestad, y muchas veces efectuando el gesto de la oratio, colmó las necesidades de representación de lo divino ${ }^{58}$. La dignidad imperial, o Maiestas, es convertida en la iconografía mayestática de Cristo y de María en sus manifestaciones de autoridad y solemnidad.

\section{La cruz de Pascual I: otro viaje a Belén}

La cruz del papa Pascual I (Fig. 6) es un relicario esmaltado que perteneció a este pontífice (reinó en 817-824) y que, entre varias escenas de la vida de María, presenta un Viaje a Belén ${ }^{59}$. La cara posterior se ha perdido y a los lados hay una inscripción dedicatoria: ACCIPE QUAESO A DOMINA MEA REGINA MUNDI HOC VEXILLUM CRUCIS QUOD TI(BI) PASCHALIS EPISC(COPUS) OPT(ULIT) ${ }^{60}$.

Las escenas ilustradas son la Anunciación, la Visitación, la Natividad (en el compartimento central), el Viaje a Belén, la Adoración de los Magos, la Presentación en el Templo y el Bautismo de Jesús. La iconografía de las escenas permite conectar al relicario con una supuesta factura oriental: la Virgen reclinada en la Natividad y la escena del Baño del Niño son motivos que provienen de

\footnotetext{
${ }^{58}$ Para un análisis detallado sobre la representación del poder en las imágenes cristológicas, ver MANZI, 1988, y MANZI, 2004.

${ }^{59}$ Está realizada en oro y esmaltes alveolados y se encuentra en la Biblioteca Apostólica del Museo Vaticano, Roma. Sus medidas son $26 \mathrm{~cm}$ de alto, $18 \mathrm{~cm}$ de ancho y $3,5 \mathrm{~cm}$ de espesor. Se desconoce el origen, pero puede suponerse que el orfebre/artista tiene relación con los modelos sirio-palestinos, aunque el inusitado color verde profundo y traslúcido del fondo no permite asimilar esta estauroteca ni con Bizancio ni con Europa. El estilo de las figuras guarda estrecha relación con la cruz Beresford Hope del siglo IX, actualmente en el Victoria and Albert Museum de Londres, que también presenta elementos orientalizantes y la misma tonalidad verde.

${ }^{60}$ HUBERT, 1968a: 354.
} 
Bizancio $^{61}$. Debido a su nacimiento puro, Jesús no necesitaba ser lavado como los otros seres humanos, pero, como se lo consideraba una prefiguración del Bautismo, la tina tiene forma de pila bautismal. La mujer que lo baña tiene los brazos desnudos, pues representa a la partera incrédula Salomé.

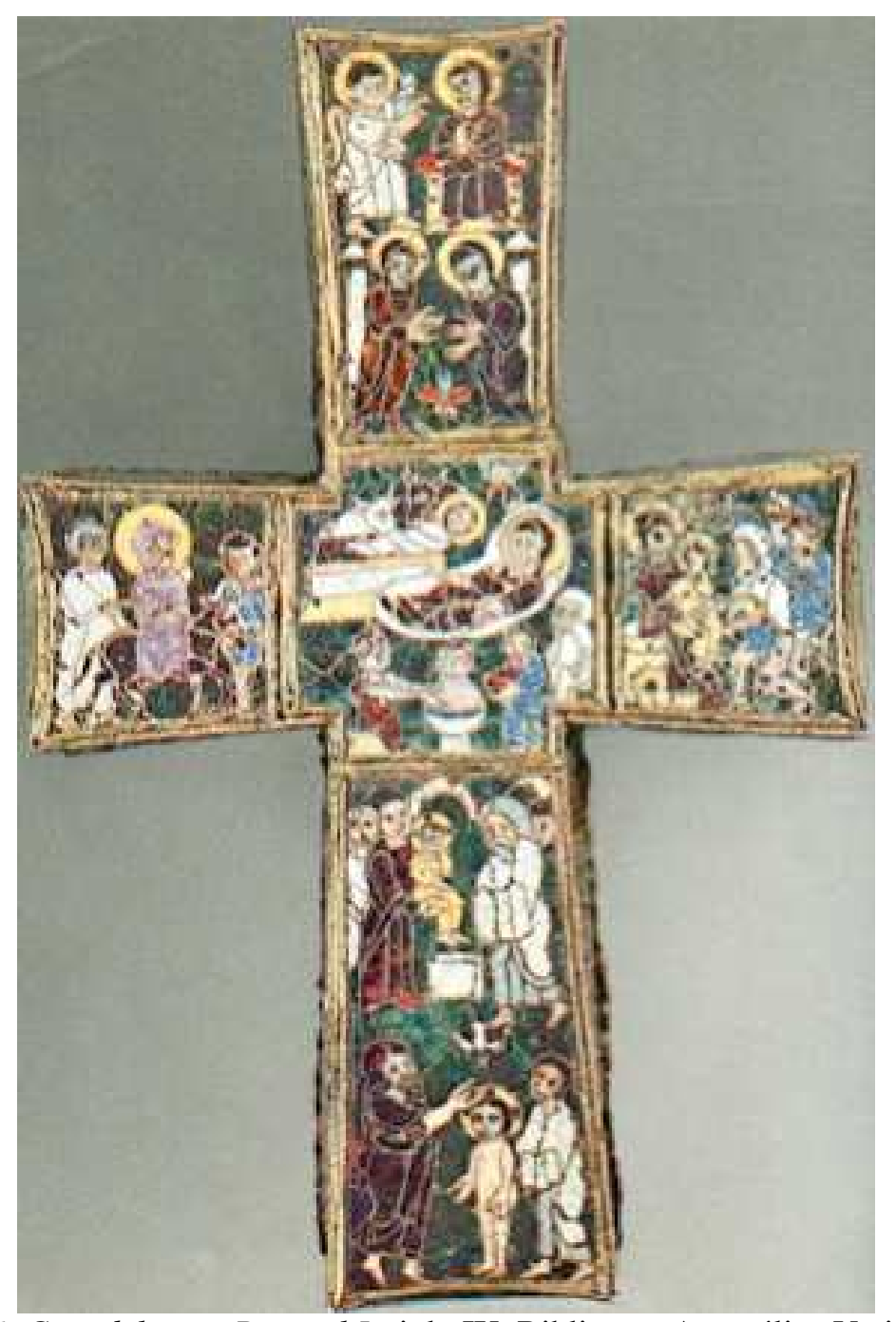

Fig. 6. Cruz del papa Pascual I, siglo IX, Biblioteca Apostólica Vaticana,

Museo Sacro, Roma, Italia, cruz esmaltada. Foto tomada de Hubert, 1968a, lámina 198.

El viaje a Belén ocupa un lugar preponderante e independiente dentro de la cruz. En una lectura de arriba hacia abajo y de izquierda a derecha, ocupa el sitio habitual entre la Visitación y el Nacimiento. Están José y Jacobo, y se observa a la Virgen a punto de dar a luz, tal como lo sugiere su voluminoso cuerpo- con un inmenso halo que ocupa aproximadamente un tercio de la parte superior de la escena.

\footnotetext{
${ }^{61}$ Según la versión sirio-bizantina, la Virgen habría parido con dolor. El concilio de Trento (15431564) decretó que el parto había sido sin sufrimiento.
} 


\section{Patricia GRAU-DiECKMANn, Representaciones de los viajes de la Sagrada Familia}

La relación familiar entre Jesús y Jacobo/Santiago no está claramente definida, pese a que los evangelios apócrifos lo mencionan para contrarrestar las numerosas referencias a los "hermanos y hermanas" en los textos oficiales ${ }^{62}$ y sostener así el dogma de la virginidad perpetua de María. Hijo del viudo José, el huérfano Jacobo/Santiago habría sido criado desde niño en la nueva familia. Algunos autores suponen que era el Adelphoteos ("el hermano del Señor"), que también puede significar que era su primo ${ }^{63}$. Al respecto, La Leyenda Dorada sostiene que Santiago el Menor era hijo de una hermana de María, llamada también María, y de un hermano de José llamado Cleofás ${ }^{64}$. Jesús y Jacobo eran muy parecidos físicamente y a menudo se les confundía. Por ello una versión sostiene que cuando Judas besa a Jesús en el jardín de Getsemaní, lo hace para diferenciarlo de su primo/hermano ${ }^{65}$. Vorágine sostiene que los judíos llamaban "hermanos" a los parientes por ambos lados, y así trata de explicar esta confusa relación familiar. Añade que Ana, madre de la Virgen María, se casó tres veces y tuvo tres hijas Marías:

"Anna solet dici tres concepisse Marias, Quas genuere viri Joachim, Cleophas, Salomeque. Has duxere viri Joseph, Alpheus, Zebedaeus. Prima parit Christum, Jacobum secunda minorem, Et Joseph justum peperit cum Simone Judam, Tertia majorem Jacobum volucremque Joannem" ${ }^{, 66}$.

Pese a la detallada explicación, Vorágine sólo agrega más confusión a una relación familiar poco clara. Sin embargo, lo cierto es que la presencia del joven Jacobo en los viajes es constante y, la mayoría de las veces, asume el control de la expedición.

\section{Iglesias talladas en la roca}

A partir del siglo IV, Capadocia (Turquía) comienza a vivir una intensa etapa religiosa, marcada por tres grandes figuras: San Basilio, obispo de Capadocia ${ }^{67}$, su hermano San Gregorio de Nisa, y San Gregorio Nacianceno. Hasta ese momento, en la Anatolia habitaban solitarios anacoretas establecidos en cavernas excavadas en las blandas rocas del lugar. Los tres santos fomentaron la fundación de monasterios, logrando que los ermitaños formaran pequeñas comunidades monásticas bajo las reglas de San Basilio el Grande. El monaquismo occidental se organizaría en grandes órdenes internacionales, como las de los benedictinos $\mathrm{y}$, muy

\footnotetext{
${ }^{62}$ Entre otros, Mt 1, 46-47 y 13, 55; Mc 3, 32; Lc 8, 19; Jn 2, 12 y 7, 3-5.

${ }^{63}$ METFORD, 1983, p. 133.

${ }^{64}$ Voragine, 1995, T. I, p. 270.

${ }^{65}$ De hecho, en las ilustraciones, Santiago presenta rasgos faciales similares a Jesús, pero es de mayor edad.

${ }^{66}$ VORAGINE, 1995, T. II: 150.

${ }^{67} 329-379$.
} 
posteriormente, los franciscanos, pero en oriente, cada cenobio era una unidad en sí misma, a veces conformada por sólo tres monjes ${ }^{68}$.

A partir del siglo $\mathrm{X}$, los valles de Ilhara y Belisirama se convierten en asilo de refugiados provenientes de Egipto, Palestina, Siria y otros lugares de Anatolia, quienes llevaron consigo sus habilidades artísticas. Capadocia florece en cientos de iglesias rupestres de clara influencia bizantina, no sólo por sus plantas en cruz griega, sino por el estilo de sus decoraciones murarias. Sin embargo, la técnica no es la típica musivárica bizantina, sino que las paredes están pintadas al fresco ${ }^{69}$.

Miles de años de erosión por lluvias y vientos gastaron el suelo, revelando conos y pirámides de formas inusuales, en los que se excavaron iglesias y habitáculos ${ }^{70}$. Hoy en día, el desgaste natural continúa, las rocas se fracturan y el agua de lluvia se infiltra por las fisuras, amenazando gravemente las pinturas de las iglesias y hasta la propia estructura, que sufre desmoronamientos. A esta destrucción se le suma la mano del hombre. Por un lado, la intolerancia religiosa lleva a dañar las figuras sacras, especialmente los rostros, y por otro, visitantes ignorantes tallan sus nombres y mensajes en las pinturas parietales. Algunos frescos han sido restaurados, otros han sido preservados naturalmente, por encontrarse en lugares prácticamente inaccesibles, pero los más se encuentran en un creciente estado de deterioro.

En Capadocia las iglesias eran pequeñas, con cúpulas de no más de cuatro metros y una nave sin divisiones ${ }^{71}$. Esto las convertía en especialmente aptas para albergar comunidades monásticas de unas cien personas del mismo sexo ${ }^{72}$. En muchos casos las fachadas han sido talladas para imitar bloques de piedra.

En Çavuşin está la iglesia, del siglo X, del Gran Palomar (Büyuk Güvercinlik) (Fig. 7), dedicada a Nicéforo Focas, en memoria de la visita que este emperador realizó entre 964 y 965 a su región natal. Su parte anterior se ha desplomado por la erosión y muchos de sus frescos, en colores marrón y verde, están sepultados bajo la tierra. Consta de una nave con bóveda de cañón corrido, en la que se ubican, al igual que en las paredes, numerosas escenas.

Existen entre sus pinturas un viaje a Belén y una llegada a Egipto, cuya ubicación de figuras es prácticamente igual en ambas escenas: la misma disposición de las manos y de las piernas, la misma vestimenta, la misma posición del caballo blanco guiado por Jacobo. En la segunda, una mujer que personifica a Egipto está en un

\footnotetext{
${ }^{68}$ AA. VV., The Glory of Byzantium, 1997.

${ }^{69}$ GRAU-DIECKMANN, 2009.

${ }^{70}$ La composición volcánica de la roca se prestaba al fácil excavado. A principios de la edad terciaria entraron en erupción dos volcanes del valle de Göreme, cubriendo la tierra con una capa de de roca volcánica blanda que se resquebrajó y separó por cambios bruscos de temperatura.

${ }^{71}$ Allí se desarrolló una escuela local arquitectónica con marcada influencia constantinopolitana, que aplicó, en general, el patrón bizantino para los interiores (planta de cruz griega, ábsides, bóvedas, cúpulas, nártex). Los escultores/constructores no abandonaron las fórmulas conocidas y tallaron innecesarios elementos de soporte (columnas, pechinas) para una estructura autosustentante (EDMONDS, 1998: 191).

${ }^{72}$ MANGO, 1975: 174.
} 
portal recibiendo a la familia. El menor tamaño de su figura destaca convencionalmente la importancia de los otros personajes.

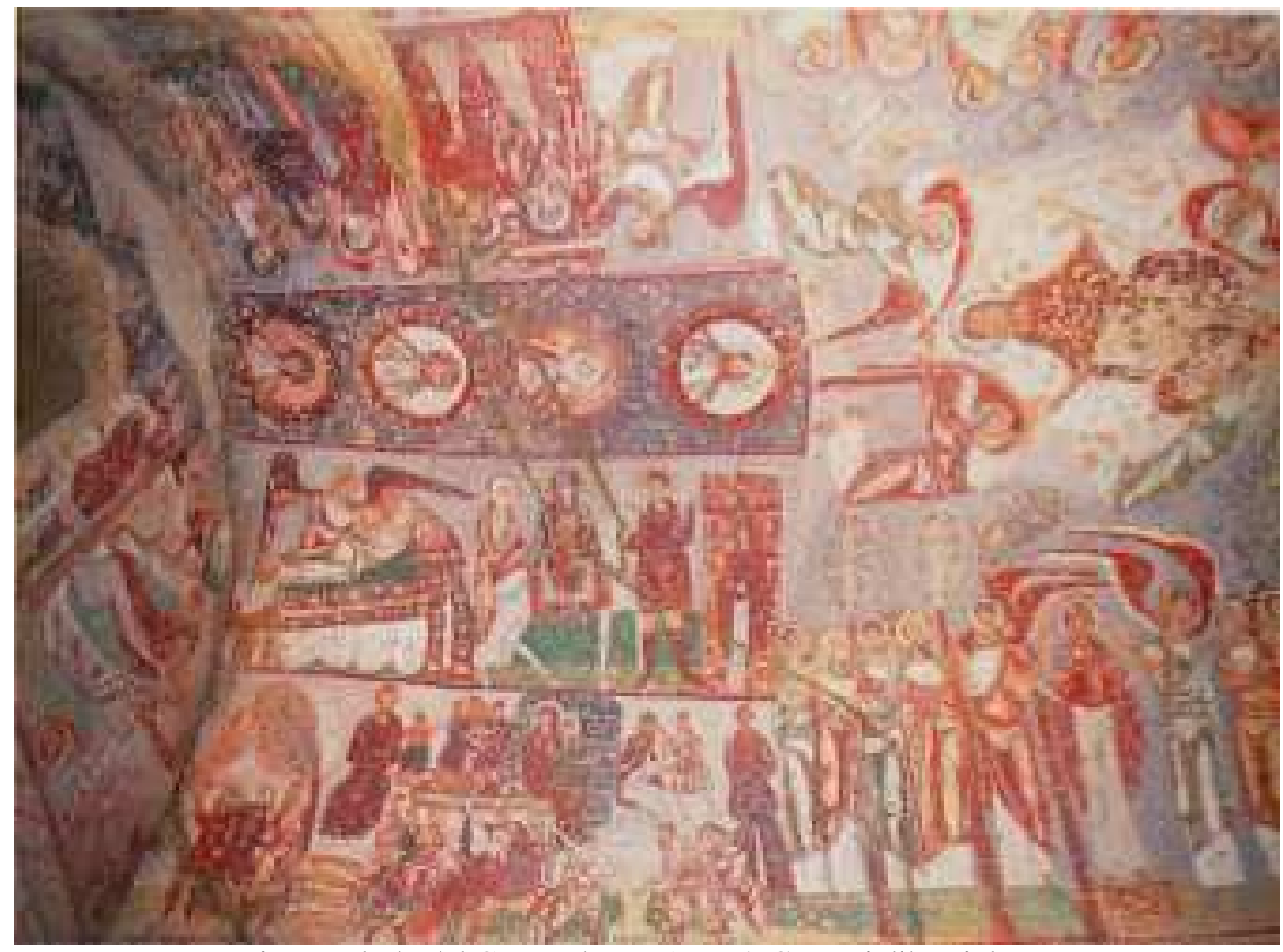

Fig. 7. Iglesia del Gran Palomar (Büyuk Güvercinlik), siglo X,

Çavuşin, Capadocia, Turquía, fresco. Foto tomada de Capadocia, p. 77.

Todas las iglesias capadocias presentan sus superficies totalmente cubiertas por pinturas, lo que permite desarrollar extensos programas iconográficos e incluso duplicar escenas. Por ello resulta muy común que los viajes de la Sagrada Familia se desplieguen en todas sus instancias (viaje a Belén, huida a Egipto, regreso a Galilea), y que también se encuentre espacio para incluir episodios laterales, como el ocultamiento en la montaña de Santa Isabel y San Juanito, o a Natanael bajo la higuera.

\subsection{Período Románico}

\section{Saint-Benoît-sur-Loire}

A principios del siglo XI, el abad Gauzlin ${ }^{73}$ inició una importante labor de restauración y decoración en la abadía de Saint-Benoît-sur-Loire (Fig. 8) ${ }^{74}$, y mandó

${ }^{73}$ Hijo bastardo de Hugo Capeto, quien reinó en Francia entre 987 y 996. 
construir una importante torre sobre el nártex, con columnas de capiteles historiados. En uno de éstos, se encuentra una fuga a Egipto, que presenta las características formales del primer románico: horror vacui, gran cantidad de motivos vegetales, y minuciosidad de los detalles.

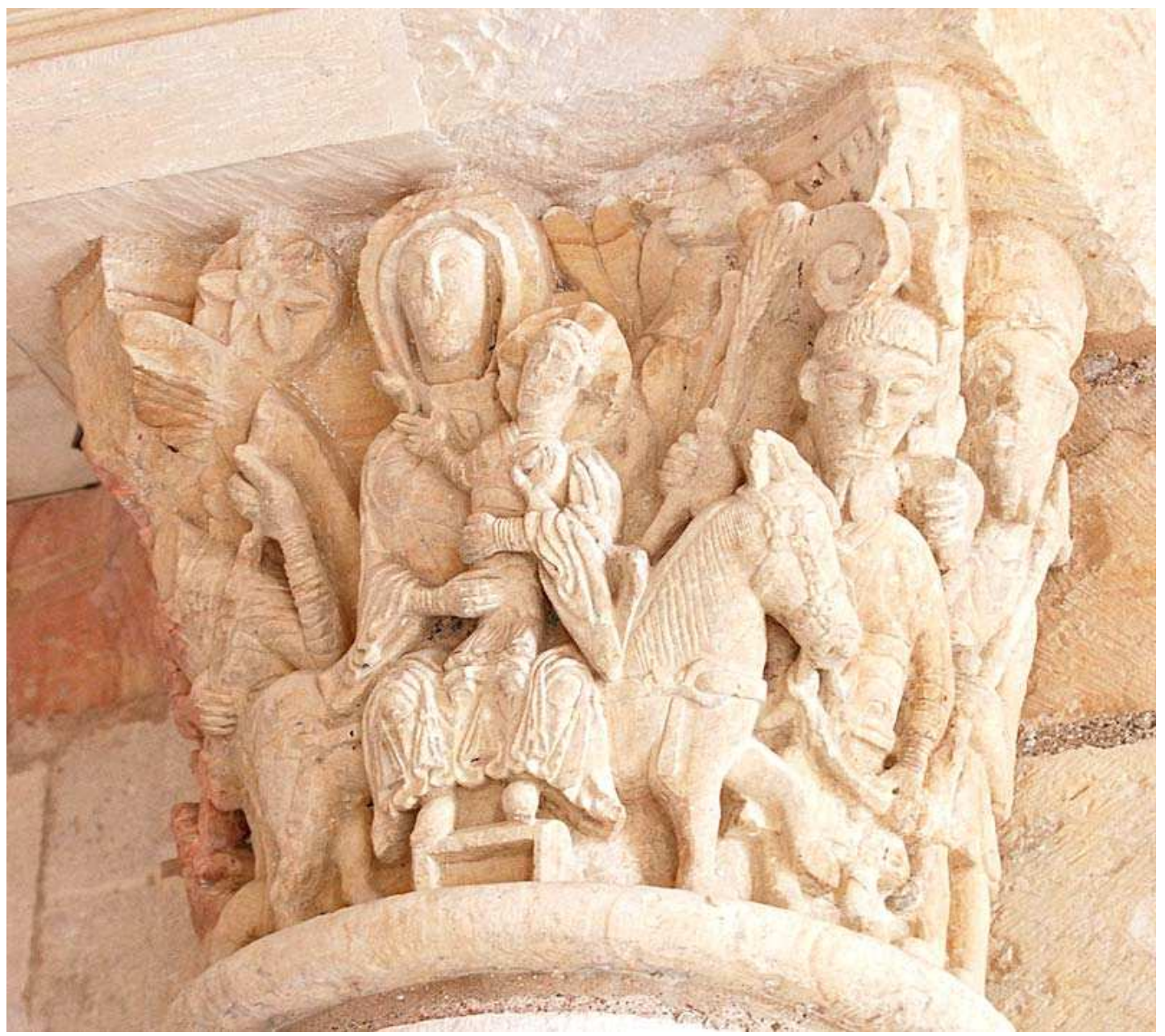

Fig. 8. Capitel del nártex, abadía de Saint-Benoît-sur-Loire, siglo XI, distrito de Orléans, Francia. Foto tomada de http://www.paradoxplace.com el 17/11/12.

La Virgen se presenta en Maiestas, sentada sobre un asno inusitadamente alargado, apoyando sus pies en un escabel ${ }^{75}$, al estilo de una entronización divina. Ella misma se convierte en Sedes Sapientiae o Trono de la Sabiduría viviente para el

\footnotetext{
${ }^{74}$ En 660 un monje de la abadía de Montecassino, devastada por los longobardos arrianos, recoge los restos de San Benito y los traslada a una antiquísima abadía en el Loire al sudeste de Orléans. Originalmente llamada abadía de Fleury o Floriacus, se cambia su nombre por el de Saint-Benoîtsur-Loire y se transforma en un prestigioso centro de peregrinación. La popularidad de la reliquia se vio favorecida por tratarse de un esqueleto completo.

${ }^{75}$ RÉAU (T.1, V.2, 1996: 268) señala cuán incongruente es representar al burro en marcha y al mismo tiempo destacar la inmovilidad mediante un escabel a los pies de María.
} 


\section{Patricia GRAU-DiECKMANN, Representaciones de los viajes de la Sagrada Familia}

Niño casi de pie, a la manera de la Virgen Hodigitria. María no está dotada de rasgos femeninos, sino que es el velo, atributo de las mujeres, lo que le asigna su carácter femenil. En el ángulo izquierdo superior está la estrella que anunció el nacimiento de Jesús ${ }^{76}$. En el ángulo derecho, la enorme mano que la señala indica la presencia de Dios Padre, una convención iconográfica que tiene su origen en las palabras hebrea yad y griega jeir, ambas con la doble acepción de "mano" y "poder". El Niño también señala a la estrella, que tiene seis puntas y está inscripta en un círculo, alusión al crismón de Constantino, formado por el monograma de Cristo, la $C h i$ y la $R o$, y que implica que, durante la Huida, Cristo estará investido de sus propios poderes como taumaturgo ${ }^{77}$.

La escena está representada convencionalmente, sin la adición de elementos apócrifos, pero su enriquecimiento está dado por los motivos simbólicos que la dotan de una resignificación peculiar, cuya lectura era seguramente comprendida por los cultos monjes del monasterio.

\section{El paliotto de Salerno}

La ciudad de Amalfi, Italia, ha dado origen - a mediados del siglo XI- a una serie de tallas heterogéneas de marfil, producidas para la catedral de Salerno, que formaban parte de puertas, relicarios, antipendios, tronos y tapas de libros. De excelente factura, son representativas de la diversidad de influencias que existía en Amalfi: tardoantiguas, lombardas, musulmanas y bizantinas. En la propia catedral de Salerno se exhibe el paliotto $^{78}$, una exquisita placa de marfil de elefante con perlas negras incrustadas en los ojos de personas y animales (Fig. 9). Tiene $24 \mathrm{~cm}$ de altura y está datada alrededor de 1084.

En la parte superior está la natividad, con María recostada al uso bizantino, que, en inusual actitud, mira a José directamente al rostro. La partera Salomé (con su brazo desnudo) y San José están a los lados de la Virgen, y cada uno prácticamente invierte el gesto del otro: se toman la cara con una mano, extienden el otro brazo, y cruzan una pierna por encima de la otra.

La escena inferior es la entrada de la Sagrada Familia a la ciudad egipcia de El Cairo, reconocible por la mezquita de Ibn Tulun, terminada en 879. Los recibe la personificación de Egipto, una mujer que sale al encuentro de los viajeros con las manos veladas en señal de respeto a la divinidad. Algunas interpretaciones señalan que esta figura femenina es Salomé, por su atributo de la vasija, ya que es una de las

\footnotetext{
${ }^{76}$ Schapiro señala que las letras OR que aparecen a cada lado de la estrella, significan "oriente", (SCHAPIRO, 1984: 191).

77 BeIGBEDER, 1995, pp. 69 y 334. Su opinable propuesta sobre la resignificación de la imago clipeata con sus seis puntas engloba muchas posibilidades (seis días para la Creación, signo "de Cristo Sol de Justicia y vencedor de las Tinieblas", etc.). Discutiblemente, también se relaciona al crismón constantiniano con lo esotérico, como alusión al Pentáculo o sello de Salomón. Para más datos, ver CHAMPEAUX, 1992 y LÉVI, 1977.

${ }^{78}$ Avril utiliza esta denominación para designar al paramento del altar (AVRIL, 1982: 274).
} 
tres mirróforas que se dirigen al Santo Sepulcro para ungir el cuerpo de Cristo con óleos y especias.

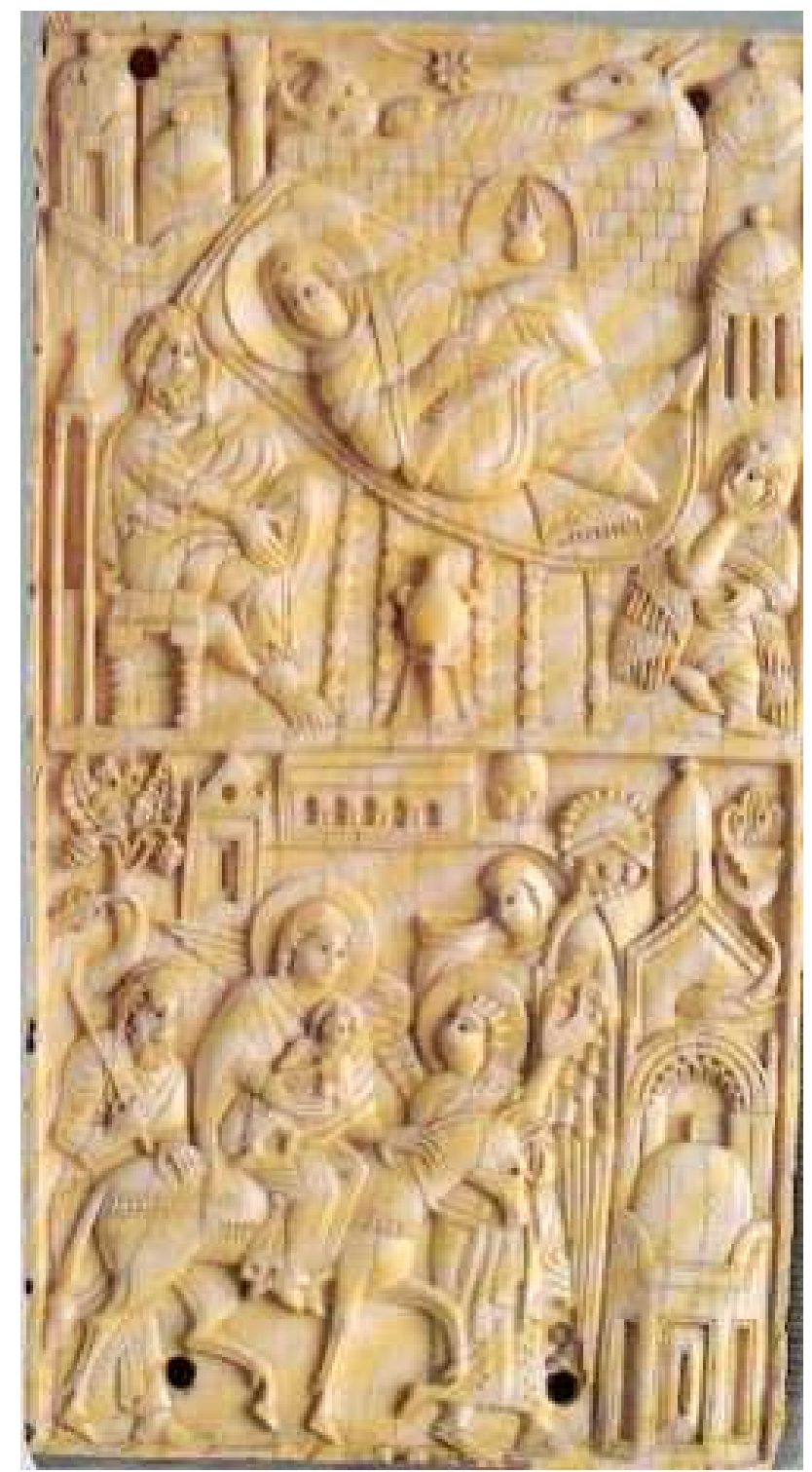

Fig 9. Paliotto de Salerno, siglo XI, Museo del Duomo, Salerno, Italia, marfil. Foto tomada de Avril, 1982, lámina 259.

La familia es guiada por el arcángel Rafael, ángel médico y patrono de los viajeros $^{79}$. Sus atributos como protector de los peregrinos son la capa de viaje, las sandalias y el cayado. Su nombre significa "Dios ha curado", pues se lo asocia con sanaciones, como las de Tobit y Abraham, a quien evitó el dolor producido durante su circuncisión. De acuerdo con Enoc 1, está "al frente de los espíritus del hombre", y por ello fue uno de los tres encargados de envolver con lienzos el cuerpo del

${ }^{79}$ RÉAU, T.1, V.1, 1996: 77. 


\section{Patricia GRAU-DiECKMANn, Representaciones de los viajes de la Sagrada Familia}

primer hombre, ungiendo a Adán con aceites aromáticos para sepultarlo ${ }^{80}$. Rafael fue también el que evitó el dolor a Jesús en su circuncisión. En este sentido, sería coherente que la mujer de la vasija fuera Salomé, ya que a ella se le encargó la custodia del prepucio del Niño, el que colocó en una redoma con aceite de nardo.

El estilo es representativo del románico del siglo XI, al que se le incorporan las influencias citadas. Los rostros son vivaces y reflejan la psicología de los personajes. Un lugar destacado lo ocupan las elocuentes manos de largos dedos, que expresan la actitud, la categoría y el mensaje de los personajes ${ }^{81}$. La condensación de numerosos elementos en el pequeño espacio dificulta la lectura de las imágenes, pero redunda en la prodigalidad de temas significativos.

\section{Icono de la Natividad}

La esencia de un icono es la atemporalidad, que se manifiesta por la repetición invariable del mismo patrón gráfico, en tanto representación del modelo o arquetipo de lo invisible que se hace visible; es la imagen "tal y como está grabada en la más íntima memoria del corazón humano" $"$.

Sin embargo, a partir del siglo XI se genera un cambio en las imágenes, y éstas comienzan a reflejar elementos de la naturaleza, incluyen narraciones y muestran la expresión de estados emotivos. Miguel Psellos señala que los iconos se convierten así en una "pintura viviente" (empsychos graphè) que "habla" al espectador y exalta sus sentimientos ${ }^{83}$. Psellos admira la filosofía de los antiguos griegos, que "conocen la naturaleza tal como la hizo el creador" ${ }^{, 4}$, y por ello cree que, en los iconos, la cercanía con la naturaleza refleja el contacto de la creatura con su Creador como ejemplo de perfección espiritual. Los iconos pintados en este nuevo estilo plasmados en pequeño formato para facilitar la devoción privada - se convierten a su vez en modelos para la siguiente generación de imágenes ${ }^{85}$. En cada acto de veneración ante este tipo de efigies, los acontecimientos sagrados - ahora representados vívidamente- son revividos una y otra vez, no sólo recordados.

Uno de estos iconos, el "de la Natividad"86 o "de Navidad", de 36,3 por 21,2 cm, fue pintado alrededor de 1100 en el Monasterio de Santa Catalina en el Monte Sinaí. Pertenece al tipo de iconos que ilustran el Himno Akathistós ${ }^{87}$, el himno mariano

\footnotetext{
${ }^{80}$ Vida de Adán y Eva (versión griega). En DíEZ MACHO, 1982, T. 2: 336.

${ }^{81}$ En la natividad, María muestra su actitud relajada con las manos en reposo, José y Salomé indican sus respectivas preocupaciones apoyando la mano en el rostro. En la huida, Rafael señala al cielo, José se incluye psicológicamente en la escena al apoyar la mano en la grupa del animal, el Niño bendice y sostiene el rollo que contiene $\mathrm{Su}$ palabra.

${ }^{82}$ QUENOT, 1990: 8.

${ }^{83}$ Citado por Belting, 1994: 261.

${ }^{84}$ Miguel Psellos, Homilía a sus discípulos negligentes (ed. J. F. Boissonade, 1938, Nürnberg; Amsterdam 1964: 151), citado por MEYENDORF, 2002: 117).

${ }^{85}$ BELTING, 1994, pp. 261/ss.

${ }^{86}$ No se incluye imagen de este icono porque lo apretado de las escenas prácticamente impide el reconocimiento de las mismas.

${ }^{87}$ BELTing, 1994, pp. 261/ss, llama a este icono "himno pintado".
} 


\section{Patricia GRAU-DiECKMANN, Representaciones de los viajes de la Sagrada Familia}

más famoso en oriente. Se calcula que este himno es anterior a la institución de la fiesta de la Anunciación en 535, por lo que remite a las más antiguas expresiones del culto a María. En general se le atribuye al himnógrafo del siglo VI Romanos el Melódico ${ }^{88}$.

Akathistós significa literalmente "no sentado" 89 , pues se canta y se escucha de pie, en señal de respeto, ya que condensa la doctrina sobre la Santa Virgen María. Se divide en una parte dogmática y una evangélica. La primera trata de la perpetua virginidad, la maternidad divina y la mediación mariana. La segunda es la descripción de una serie de escenas relacionadas con el nacimiento de Jesús, como las que se ilustran en este icono: los magos guiados por la estrella; la entrega de los presentes a Jesús; el regreso a su tierra; la anunciación a los pastores; la llegada de las comadronas guiadas por Jacobo; el baño del Niño; el sueño de José; Isabel y Juan ocultos en la montaña; la llegada a Egipto; Herodes y la Matanza de los inocentes.

Es éste un programa iconográfico muy amplio que abarca numerosos episodios, en los que coexisten historias apócrifas y canónicas. Las escenas tienen cada una su propio y acotado espacio en laderas montañosas o en paisajes abiertos, distribuidas alrededor de la caverna con el pesebre. Se trata de la traducción visual del himno Akathistós, con una disposición rítmica de la estructura del poema, cuyo núcleo es María y lo que sucede en torno a su alumbramiento ${ }^{90}$. La multiplicidad de ilustraciones que presenta este tipo de iconos ha permitido la inclusión, en muchos casos, de escenas secundarias anecdóticas, como las de Santa Isabel con San Juanito y la de Natanael bajo la higuera ${ }^{91}$.

\section{Representaciones litúrgicas populares}

A partir de la Primera Cruzada se incrementan las representaciones de la huida a Egipto, pues los viajeros exaltaban la imaginación de artistas y artesanos con sus relatos sobre tierras lejanas y exóticas. Adicionalmente, la profundización de la devoción mariana induce a los hombres —aun a los más belicosos y rudos - a reconocer en María no sólo a la Madre de Dios, sino también a la de todos aquéllos que imploran su intercesión. Protege, consuela y acoge a los que sufren. A su vez, los feligreses se compadecen de esa madre humana que huye para salvar a su hijo. Otro factor determinante son los dramas litúrgicos y las escenificaciones que rescatan los vínculos originales populares con las historias sagradas sobre la natividad y la pasión, y que además enriquecen la iconografía tradicional.

\footnotetext{
${ }^{88}$ MEYENDORF, 2002: 60, afirma que los poemas de Romanos fueron fundamentales para la transmisión de las historias bíblicas a las masas populares, en especial este himno, determinante para el desarrollo del cristianismo bizantino.

${ }^{89}$ Del griego: a: negativo; kathistomai: sentarse.

${ }^{90}$ BeLTiNG, 1994: 281.

${ }^{91}$ Para imágenes del niño Natanael bajo la higuera, ver Icônes grecques, melkites, russes, 1993: 324.
} 


\section{Patricia Grau-DieCKMANN, Representaciones de los viajes de la Sagrada Familia}

Una de las representaciones favoritas era la de la huida, ya que permitía no sólo mantener el sentido religioso, sino dar rienda suelta a los sentimientos lúdicos e incluso mordaces. La víctima era José, a quien se lo presentaba como torpe, ridículo, avariento y amante del vino ${ }^{92}$. Documentos del siglo XII procedentes de la catedral de Beauvais registran una insólita representación, en la que una joven montada en un burro y con un niñito en brazos entraba a la catedral rumbo al altar. Durante la misa, las partes finales del Introito, Kyrie, Gloria y Credo se coronaban con la denominada "prosa de burro", que era la imitación de un rebuzno, coreado incluso por el propio celebrante ${ }^{93}$.

En la ciudad de Ruan este tipo de procesión era aún más atrevida, ya que, mientras el sacerdote repetía tres veces Dominus vobiscum, la cola del animal se jalaba tres veces para sincronizar la bendición con el rebuzno auténtico ${ }^{94}$. La llamada "celebración de los burros" deriva de una representación dramática de un episodio del Antiguo Testamento, que se insertaba en la liturgia de Navidad, el Processus Prophetarum ("la procesión de los profetas"), muy popular en la picaresca medieval. En ella se incluía a la burra de Balaam, adivino de los moabitas, a quien su rey le encomienda maldecir a Moisés y a los hebreos, que venían huyendo de Egipto. Balaam se dirige a pronunciar sus palabras de abominación, montado en un asna, cuando es interceptado por un ángel enviado por Dios. Se arrepiente, bendice a los judíos y les profetiza un futuro glorioso.

Las escenificaciones basadas en las historias religiosas estaban inspiradas en un sentimiento devocional, pero también reflejaban sentimientos rayanos con la impiedad. Por ello, las autoridades eclesiásticas decidieron prohibir las representaciones populares con burros reales ${ }^{95}$. Debió pasar mucho tiempo, sin embargo, antes de que estas costumbres escandalosas fueran totalmente abandonadas por el pueblo.

\section{Saint-Lazare d'Autun}

La ciudad de Autun en la Borgoña era llamada la Roma céltica (soror et aemula Romae $)^{96}$. Entre sus motivos de orgullo estaba la posesión de los restos de Lázaro, enterrado detrás del altar mayor bajo un baldaquino de mármol negro en la iglesia catedralicia, comenzada en $1120^{97}$. Los monjes de la catedral "hermana" de Santa Magdalena en Vézelay fomentaron la leyenda de Lázaro, pues el área borgoñona se estaba convirtiendo en el arranque de uno de los cuatro caminos a Santiago de Compostela, la "Vía Lemovicensis" (nombre latino de Limoges) ${ }^{98}$.

\footnotetext{
${ }^{92}$ RÉAU, T. 2, V. 4: 164,

${ }^{93}$ GRAU-DIECKMANN, 2009.

${ }^{94}$ SWAAM, 1984: 34.

${ }^{95}$ GRAU-DIECKMANN, 2009.

${ }^{96}$ RÉAU, 1946: 15.

${ }^{97}$ El sepulcro se conservó intacto hasta la Revolución Francesa.

${ }^{98}$ AA.VV., 1997, Romanesque: 277.
} 


\section{Patricia GRAU-DiECKMANN, Representaciones de los viajes de la Sagrada Familia}

El auge de la peregrinación compostelana en el siglo XI se debe a que en esa época la atención de los dirigentes de la Iglesia se vuelca a los textos evangélicos ${ }^{99}$. En dicha abadía de Vézelay se forja en el siglo XI la historia de los tres hermanos, Marta, Magdalena y Lázaro, que refiere que fueron lanzados al mar en una barca sin timón ni piloto. Los acompañaban el obispo Maximino —uno de los 72 discípulos, Cedonio, el ciego de nacimiento curado por Jesús, María la de Cleofás, y María Salomé, la del Zebedeo. Guiados por la mano divina, recalan en el puerto de Massilia, hoy Marsella, en la Provenza. La leyenda cuenta que Lázaro murió y fue enterrado en esas tierras, pero los monjes borgoñones explican que ellos mismos robaron sus restos para protegerlos de los sarracenos, y los trasladaron a la abadía de Autun (la antigua ciudad romana de Augustodunum).

A comienzos del siglo XII, una famosa escuela de escultores trabajó en esta catedral - construida con el típico estilo maduro del románico borgoñón ${ }^{100}$ — bajo la dirección del maestro Gislebertus. Su firma, "Gislebertus hoc fecit", se encuentra en el tímpano de la entrada occidental a los pies del Cristo del Juicio Final ${ }^{101}$.

Los capiteles historiados de Saint-Lazare presentan dos detalles sorprendentes (Fig. 10). Las figuras están aplanadas, a pesar de que se trata de tallas tridimensionales, y por otro lado las fisionomías son personales y reconocibles en todos los capiteles. La Virgen María, San José, los Magos presentan los mismos e identificables rasgos en las distintas escenas.

El capitel con la Huida a Egipto, tallada por el propio Gislebertus, proporcionará la clave para comprender el motivo de dichas características ${ }^{102}$. Allí se observa a José, que guía por la brida al animal, que muestra la pata demasiado levantada, en un intento del artista por enfatizar la idea de movimiento que no condice con la realidad de la marcha de un cuadrúpedo. El conjunto no se apoya sobre una base horizontal que se asemeje al suelo, sino que lo hace sobre unas formas circulares, que parecen ruedas decoradas. Sobreviven documentos que mencionan que en la ciudad de Autun tenían lugar celebraciones religiosas populares, como los "juegos del Santo Leproso" en honor de Lázaro, patrono de los malatos ${ }^{103}$. Entre los autos sacramentales, las escenas de la Huida a Egipto gozaban de gran favor y, para

\footnotetext{
${ }^{99}$ La cristiandad latina sólo poseía en Compostela los restos de Santiago el Mayor, representante de esos primeros discípulos. Las reliquias del Príncipe de los apóstoles, Pedro, eran indirectas, no corporales. En Roma estaban sus llaves, sus cadenas y su cátedra (RÉAU, 1996, T.2, V. 5: 48). Su tumba fue descubierta e identificada en el siglo XX. Se desata una carrera para encontrar reliquias y fabricar leyendas que justificaran la presencia de algunos de los primeros discípulos en occidente, situación que coincide con la necesidad de incrementar la prosperidad de la abadía de Vézelay.

${ }^{100}$ KUBACH, 1974, pp. 169-170.

${ }^{101} \mathrm{Su}$ escuela se caracteriza por el uso de patrones delicados con líneas muy marcadas, una elongación de las proporciones del cuerpo humano y el uso frecuente de los bordes de los drapeados levantados, como movidos por el viento.

${ }^{102}$ En el siglo XIX varios de los capiteles bajo la torre central fueron removidos a la sala capitular ante un peligro de derrumbe, entre éstos la Huida, el Cuestionamiento de Dios a Caín, el Ahorcamiento de Judas y la Adoración de los Magos.

${ }^{103}$ RÉAU, 1996, T.2, V. 4: 232.
} 
conformar a las autoridades eclesiásticas, los verdaderos animales fueron remplazados por burros de madera, que, a su vez se emplazaban sobre carros con ruedas, que permitían al conjunto ser empujado o jalado con facilidad.

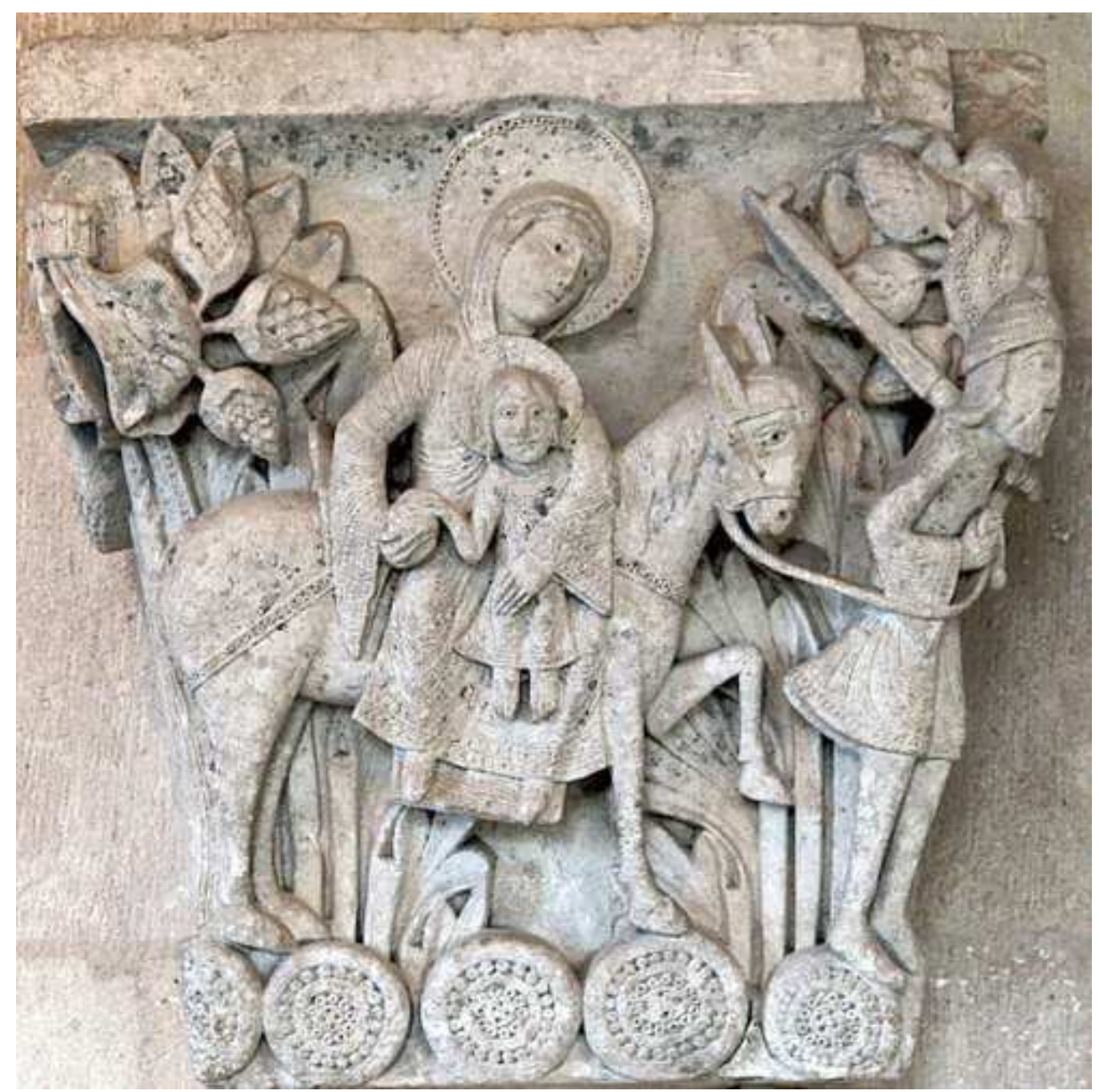

Fig. 10. La Huida a Egipto, capitel, catedral de Saint-Lazare de Autun, Francia, siglo XII. Foto tomada de http://www.paradoxplace.com el 27/11/2012.

Gislebertus, con sus personajes aplanados y las ruedas que soportan al conjunto, reproduce las figuras y el burro de utilería, en clara referencia al teatro medieval. La reiteración en los capiteles de los rostros de los protagonistas se debe a que el maestro muestra a los verdaderos actores de los autos, cada cual con su fisonomía. En Saint-Lazare d'Autun, no se reflejaron las verdaderas historias, sino las representaciones de las auténticas historias ${ }^{104}$. Es notable cómo la influencia del pueblo llano invade ámbitos artísticos eruditos ${ }^{105}$. Si bien los misterios eran fuente de inspiración y piedad en la devoción popular, también reflejaban situaciones en que afloraban sentimientos no del todo ortodoxos, muchas veces irreverentes. La

${ }^{104}$ GRAU-DIECKMANN, 2009.

${ }^{105}$ MÂLE (1952, pp. 18/20) indica que la influencia de los misterios se advierte, a partir del siglo XII, en imágenes que representan el "Encuentro en Emaús". 


\section{Patricia Grau-DieCKMANN, Representaciones de los viajes de la Sagrada Familia}

Iglesia debió mediar para contemporizar las atrevidas manifestaciones, pero no logró acallarlas del todo. Es más, la iconografía fue notoriamente enriquecida por influencia de los dramas litúrgicos.

\section{Un regreso a Galilea}

El salterio de San Albano ${ }^{106}$ fue producido en el monasterio benedictino de San Albano, Inglaterra, durante el priorato de Geoffrey de Gorham, entre 1119 y 1146. Se cree que el manuscrito originariamente se planificó para contener sólo salmos, pero que antes de ser terminado fue modificado para el uso de la religiosa Cristina de Markyate, protegida espiritual de Geoffrey ${ }^{107}$. Para adecuarlo al uso de Cristina, se agregó al inicio un calendario litúrgico. También se adicionaron 40 miniaturas a toda página con representaciones de la Caída y escenas de la Vida de Cristo, una carta escrita en francés y en latín, en la que el papa Gregorio I incita al uso de las imágenes como medio de catequización, y la Canción de Alexis, inclusión sumamente adecuada ya que el santo, al igual que Cristina, había abandonado a su cónyuge la noche de bodas para permanecer fiel a su voto de castidad.

Trabajaron en él cuatro artistas. El principal es el llamado Maestro de Alexis, que trabajó en las miniaturas de la Caída y de la Vida de Cristo, y en la Canción de Alexis. Estas páginas son las más tempranas en estilo románico inglés que han llegado hasta nuestros días, y demuestran que el autor estaba al tanto de lo que sucedía artísticamente en Europa y en el resto de Inglaterra. Sus figuras son elongadas, de largas piernas y hombros caídos o angostos, cintura pequeña y los pies, bien románicos, no parecen dar sustento a los personajes, sino que aparentan dar pasos de baile en el aire. Las manos son muy grandes y gestualmente expresivas. El estilo compositivo de las figuras humanas es el que utilizaban los egipcios: rostros, brazos y piernas de perfil y torso de frente. Las narices de los personajes, muy destacadas, están formadas por una línea recta que nace en la frente, pero la barbilla está hundida las más de las veces, lo que hace que los ojos, de por sí grandes, lo parezcan más. Las vestimentas son ajustadas y se trasluce la forma del cuerpo, en especial los muslos, a través de la tela. Los pliegues, marcados circularmente por líneas oscuras y claras, colaboran para la obtención de este efecto.

\footnotetext{
${ }^{106}$ Se trata de un códice de 209 folios, que mide 27,6 por $18,4 \mathrm{~cm}$, y actualmente se encuentra en el tesoro de la Biblioteca de la Catedral de Hildesheim, Alemania. Los pergaminos empleados presentan diferentes colores y a simple vista se pueden distinguir los lados del pelo de los de la carne, que son suaves y muestran señales del cuchillo con que fueron trabajados. Algunas miniaturas todavía poseen el hilo rojo con que se fijaban las cubiertas de seda para la protección de las miniaturas particularmente valoradas. En 2003 la Universidad de Aberdeen, Escocia, puso a disposición del público un exhaustivo estudio sobre el salterio. Gran parte de la información aquí volcada se encuentra en la página http://www.abdn.ac.uk/stalbanspsalter/, consultada el 21/08/2009. Los folios mencionados pueden ser analizados en este sitio, al igual que la totalidad de las miniaturas e iniciales.

${ }^{107}$ Para un análisis sobre la vida de Cristina y la fuerte ligazón espiritual que existía entre ambos, ver GUGLIELMI, 2007-2008, pp. 11/ss.
} 


\section{Patricia Grau-DieCKMAnN, Representaciones de los viajes de la Sagrada Familia}

Cada miniatura ocupa 18,1 por 14,1 cm de la página, y está cerrada por marcos, todos de diferente diseño, a su vez delimitados por bordes de pintura de oro. Como rasgo típico del románico, el marco no es restrictivo de la acción y se colocan detalles que sobresalen de éste casi imperceptiblemente, como porciones de pies, de manos, del ala de un ángel, del pináculo de un edificio, etc. Las ilustraciones reflejan las representaciones sacramentales; por ello las arquitecturas están presentadas a la manera de los fondos teatrales, con arcos y otras aperturas que permitían la entrada y salida de los actores. Son fondos escénicos delante de los cuales se ubican los personajes.

Los folios 29r, 30v y 31r ilustran la Huida a Egipto, la Matanza de los Inocentes y el Regreso a Galilea. Las tres escenas formaban una secuencia en el Ordo Rachelis, auto milagroso que se representaba en Fleury, y que es una de las escasas dramatizaciones que incluían el regreso de Egipto. Se representaba el 28 de diciembre, día de los Santos Inocentes, y se combinaba el episodio de Raquel y la muerte de sus hijos con la masacre de los niños por Herodes. Una iconografía inédita, que surge de la puesta en escena, es la de las madres que luchan a brazo partido contra los soldados. Como curiosidad, en esta miniatura destaca una mujer, que, en su desesperación, muerde la pierna de un soldado.

Las dos escenas de viaje son casi idénticas en lo formal: la huida es guiada por Jacobo y el grupo se encamina hacia la derecha, cerrando el grupo José con un cayado de caminante, su hacheta de carpintero y odres para el agua. María monta "a la amazona", por lo que sus piernas se ubican sobre el flanco izquierdo del animal, como corresponde a este estilo ecuestre y, por lo tanto, sus piernas no son visibles para el espectador. Sí lo serán en el regreso a Galilea, pues la caravana se dirige hacia el lado opuesto. José lleva en la mano los mismos elementos y sólo se han modificado los colores de los ropajes, no así el modelo ni la forma de llevarlos. Sin embargo, las expresiones faciales son notoriamente de alegría y de alivio. La iconografía más común para el tema es la de José llevando al Niño sobre sus hombros, aunque, de cualquier manera, el motivo del regreso a Galilea no gozó de demasiada popularidad ni en occidente ni en oriente.

\section{Los Santos Inocentes}

Durante el siglo XII trabajaban en la zona del Lacio, Italia, familias de marmolistas especializadas en la factura de mobiliario litúrgico, particularmente en tallas. Uno de estos elementos mobiliarios era el candelabro, que descendía de los grandes candelabros romanos, y que consistía en una gruesa columna de bronce o de mármol que se elevaba sobre una base o pedestal similar al altar, donde se ubicaban velas o lámparas. El fuste estaba tallado en registros superpuestos, que ilustraban diferentes escenas sacras.

En la catedral de Gaeta - al noroeste de Nápoles - existe un candelabro de mármol de fines del siglo XII con escenas de la Infancia y Pasión de Cristo y de la vida del santo protector de la ciudad, San Erasmo, dispuestas en registros enmarcados (Fig. 11). 


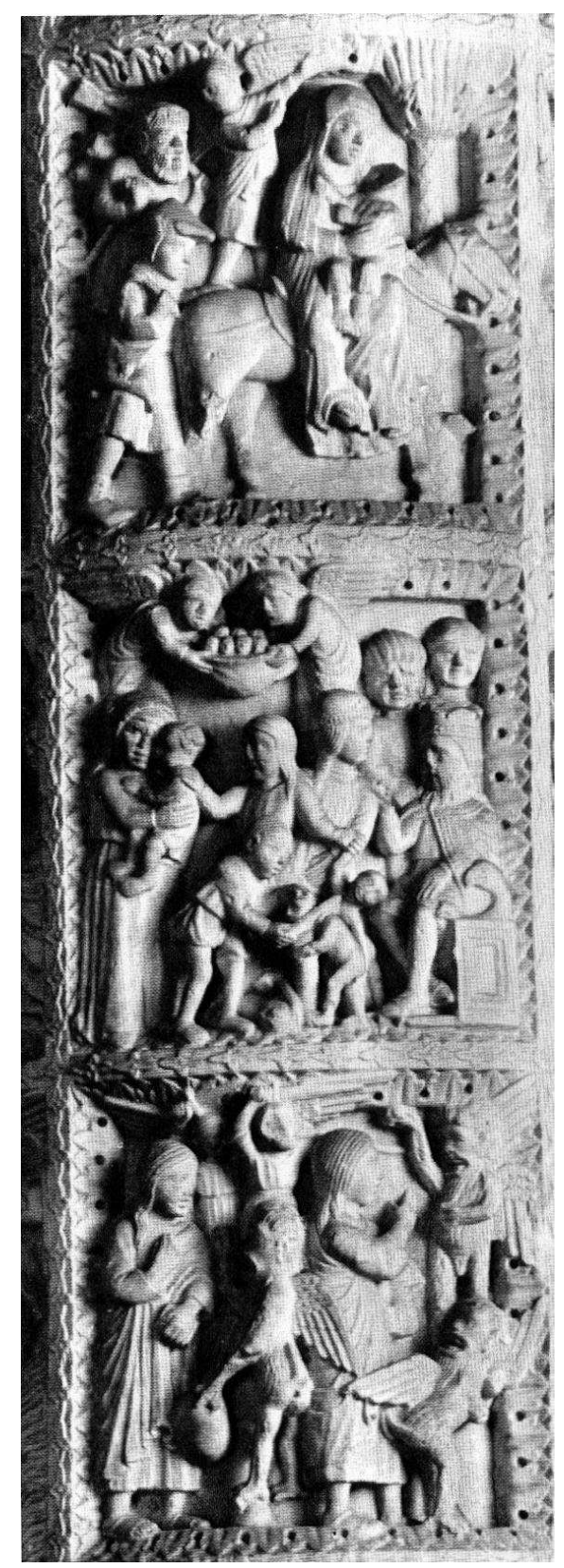

Fig. 11. Candelabro de la catedral de Gaeta, Italia, siglo XII, piedra. Foto tomada de Avril, 1982, lámina 77.

En uno de estos registros verticales aparecen dos escenas relacionadas temática y cronológicamente, la Huida a Egipto y la Matanza de los Santos Inocentes. En ésta última aparece Herodes en su trono, que contempla impasible cómo los niños son decapitados por los soldados. En lo alto, dos ángeles recogen en un lienzo ahuecado las almitas de los pequeños, simbolizadas como cabecitas. Esta iconografía se refiere al "seno de Abraham", que es donde serán acogidas las almas cuando, tras el Juicio Final, accedan al Paraíso. Esta imagen deriva de la parábola (Lc 16,19-33) sobre las 


\section{Patricia GRAU-DiECKMANN, Representaciones de los viajes de la Sagrada Familia}

muertes del pobre Lázaro ${ }^{108}$ y el rico epulón. Este último, desde el infierno, ve a Lázaro en un ágape celestial recostado sobre el seno de Abraham. Es ésta una referencia a la intimidad de quien se recuesta durante el banquete en el pecho de su vecino. La palabra griega para regazo, pecho - la usada por Lucas - es kolpos, y también se refiere al pliegue de un vestido o al bolsillo de la toga ${ }^{109}$. Una errónea interpretación del vocablo se tradujo plásticamente en la figura de Abraham sosteniendo entre sus manos un paño combado donde se alojan las almas de los que acceden al Paraíso.

En la Huida propiamente dicha del candelabro de la catedral de Gaeta están la Virgen con el Niño sobre un caballo, San José con un atado y la hacheta de carpintero, y Jacobo. En segundo plano, un ángel señala hacia la palmera. Probablemente no aluda al milagro de los dátiles, sino al atributo de los que han padecido suplicio, ya que los Santos Inocentes son considerados los primeros mártires del cristianismo. Jesús se salva de la matanza como otros héroes históricos o legendarios que escaparon en la temprana infancia a la muerte o exposición ordenada por un rey (Paris, Hércules, Moisés, Rómulo). En este sentido, es probable que Mateo $(2,16)$ —el único evangelista que da cuenta del suceso- haya forzado su testimonio para encontrar la correspondencia tipológica con lo que se considera una profecía de Jeremías $(31,15)$ "En Rama se oyeron las voces, muchos lloros y alaridos: Raquel que llora a sus hijos sin querer consolarse porque ya no existen".

La representación de la Huida en un candelabro es indicio de que a partir del siglo XII el auge y la popularidad de esta escena redundarán en la utilización de soportes no tradicionales, como puertas de iglesias, miniaturas, vitrales y mobiliario litúrgico. Un rasgo característico de muchas obras de este período es que algunos elementos de las figuras sobrepasan el marco que las limita. En este caso, lo que sobresale son los dos ángeles, que, superponiéndose al borde del panel, recogen las almas de los niños.

\subsection{Período Gótico}

Durante el gótico, arte predominantemente urbano, los scriptoria monásticos paulatinamente irán transformándose en talleres laicos. Los Viajes de la Sagrada Familia que se representan en este siglo son poco innovadores y puede afirmarse, incluso, que la temática ha sufrido una remisión en su expresión creativa, encontrándose la mayor parte de las obras en los portales de las catedrales. Entre las razones para la disminución de este tipo de imágenes está el auge de las representaciones de los santos, y de sus leyendas y sus milagros, fomentado por los escritos, entre otros, de Jacobus de Voragine y de Vicente de Beauvais. Se prefieren las ilustraciones del Antiguo Testamento en tanto prefiguración y afirmación

\footnotetext{
${ }^{108}$ Un mendigo con lepra que terminó por identificarse con Lázaro el resucitado. De ahí el patronazgo de San Lázaro sobre los leprosos.

${ }^{109}$ Clave Lingüística..., 1986: 169. ARNDT, 1967: 443.
} 
doctrinaria del Nuevo, y motivos como los de la coronación de la Virgen y los Juicios Finales ${ }^{110}$.

\section{Vitrales de la catedral de Laon}

La edificación primitiva de la catedral de Laon, Francia, ha sido datada entre 1165 y 1205, pero se realizaron posteriores modificaciones. Su rasgo más sobresaliente son las torres con dieciséis toros que se asoman mirando hacia la ciudad, homenaje al milagro de la carreta que transportaba piedras para su construcción, y que quedó atascada por la pesada carga. Incapaces de moverla, los trabajadores vieron cómo un toro majestuoso aparecía y los sacaba del apuro, tirando de la carreta, para luego desaparecer misteriosamente. Distintos episodios relacionados con la fuga a Egipto ocupan - en el coro de 1215- seis medallones ubicados en tres registros horizontales y dos verticales, cuya lectura es de izquierda a derecha y de arriba abajo).

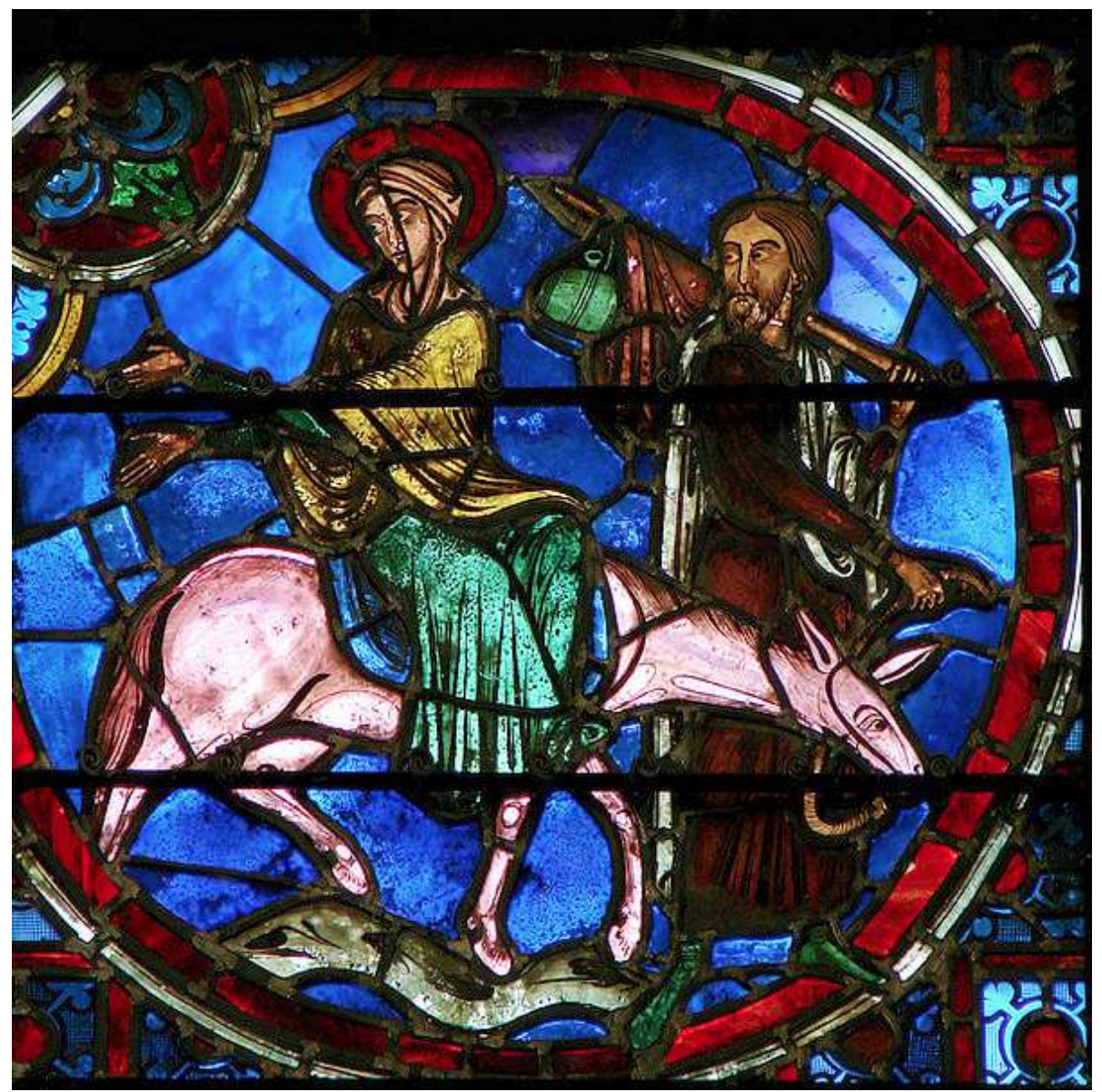

Fig. 12. Vidriera del coro, catedral de Laon, Francia, 1215. Foto tomada de http://commons.wikimedia.org/wiki/File:Vitrail_Choeur_Laon_el 29/11/2012.

${ }^{110}$ Sostiene Mâle que "durante los siglos XII y XII, la doctrina encarnó, simultáneamente, en los personajes de los dramas litúrgicos y en las estatuas de las portadas." (1952: 82) 


\section{Patricia GRAU-DiECKMANn, Representaciones de los viajes de la Sagrada Familia}

Comienza cuando Daniel profetiza la caída de los ídolos al interpretar el sueño de Nabucodonosor ${ }^{111}$. Su correspondencia tipológica se representa, a la derecha, con dos estatuas que caen de sus pedestales, significando la caída de las efigies que se desploman cuando Jesús entra a las ciudades egipcias. Sugestivamente, el texto que concuerda con Daniel no es canónico, señal de que las narraciones pseudoepigráficas son seriamente consideradas, a pesar de su anatematización ${ }^{112}$. Los dos medallones centrales muestran al ángel alertando a los Magos que no deben regresar junto a Herodes, y a los tres Reyes Magos cabalgando.

Finalmente, se ilustra el episodio en el que María hace un alto en su casa para despedirse de sus parientes antes de partir para Egipto (Fig. 12). Dos figuras femeninas con halo le entregan el Niño a la Virgen, que ya está montada en un burro y extiende los brazos para alzar a Jesús. El culto marial, que se remarca con ese gesto de María de acogimiento, no sólo significaba que los grandes hombres (reyes, santos) encontraban en Ella su refugio, sino que concede al hombre común, incluso al pecador, la posibilidad de encontrar en la Madre de Dios una aliada y una intercesora ante su Hijo. San José con un lío en la vara, guía al asno y vigila la escena con mirada atenta. Esta preocupación, que se manifiesta en la cabeza volteada, es una característica del arte del siglo XIII.

La forma de representar a los ídolos descalabrados recuerda los modelos similares de las ilustraciones inspiradas en los Comentarios al Apocalipsis de Beato de Liébana (c. 776) y a los cronológicamente más próximos frescos de la catedral de San Isidoro de León (c. 1100), ambos en España. La curvatura de los cuerpos y la manera de separar los talles de las piernas revelan la influencia de los Beatos, influencia que también se observa en los centros artísticos franceses y españoles ${ }^{113}$.

La vidriera de la catedral de Laon recurre a leyendas que, lejos de desaparecer, irán afirmándose en los dos siglos siguientes. La vigencia de las fuentes apócrifas, a las que se les agregará la reciente Leyenda Dorada de Vorágine, indican a las claras que los fieles - ahora burgueses - comprendían perfectamente a qué aludían las imágenes, fuera por lectura o fuera por relatos orales. La catedral no es un ámbito religioso restringido, sino que está al alcance de todas las personas, más allá de su nivel social y económico. Todos, ricos y pobres, analfabetos y letrados, laicos y religiosos, nobles y plebeyos, comprendían el significado de las imágenes apócrifas.

\footnotetext{
111 Daniel 2, 31-36: "Así la veías tú [a la estatua] cuando, sin que mano ninguna la moviese, se desgajó del monte una piedra, la cual hirió la estatua en sus pies de hierro y de barro, y los desmenuzó (...).”

${ }^{112}$ El citado Edicto Gelasiano concluye, tras enumerar los textos que se rechazan: "Éstos y otros escritos similares (...) no sólo no sólo son repudiados por toda la Iglesia Católica Apostólica Romana, sino que deben ser eliminados los autores y sus seguidores, y condenados con el indisoluble vínculo del anatema eterno." (En RANKE-HEINEMANN, 1995: 196).

${ }^{113}$ MÂlE (1952: 10/12) asegura que una versión del Beato de Saint-Sever se encontraba en el monasterio de Moissac y que influyó al arte de la época.
} 


\section{Patricia GRAU-DiECKMANN, Representaciones de los viajes de la Sagrada Familia}

\subsection{El siglo $\mathrm{XIV}$}

En el transcurso del siglo XIV, los viajes representados son cada vez más numerosos y presentan la variedad estilística que es propia de este siglo de transición artística. Conviven estilos y soportes plásticos (mosaicos, miniaturas, dípticos, etc.). El culto mariano, ya definitivamente instalado, favorece las escenas familiares que permiten al hombre común identificarse con la Sagrada Familia y sus tribulaciones. El arte abandona su refugio monástico y encuentra expansión en los centros urbanos, tendencia que ya se insinuaba en los siglos anteriores. Muchas obras son encargadas y financiadas por comitentes particulares. Se conocen los nombres de los creadores, se saben muchos detalles de sus vidas, de sus itinerarios artísticos, de los contratos con sus protectores y de la paga que recibían por su trabajo, información poco disponible hasta ese momento. El artista ha dejado atrás el virtual anonimato: a partir de ahora, los grandes creadores tienen existencia palpable y reconocida: Giotto, Duccio, Broederlam. La cultura se laiciza y esto se refleja en el arte: aparecen obras profanas y se introducen temas mundanos en las obras religiosas.

\section{Capilla Scrovegni - Giotto di Bondone}

Giotto di Bondone ${ }^{114}$ pintó, en la capilla de la Arena o Capilla Scrovegni, de Padua, una serie de frescos de 2 por $1,85 \mathrm{~m}$ cada uno, con los ciclos de María y de Jesús (Fig. 13). La iglesia, construida entre 1303 y 1306, fue pensada desde un principio como espacio arquitectónico para albergar las pinturas, y se cree que el arquitecto fue el propio Giotto. Las escenas están inspiradas tanto en los evangelios canónicos como en el Protoevangelio de Santiago. Giotto aborda los temas cristianos con un enfoque personal e íntimo, influido por las órdenes mendicantes, en especial los franciscanos, que contribuyeron para que la religión se transformara en una experiencia personal e íntima ${ }^{115}$. Por ello, los sentimientos de los personajes se reflejan en una atmósfera serena e intensa. Su dramatización de las narraciones religiosas refleja una aguda comprensión del comportamiento humano que maravilló a sus contemporáneos y que continúa conmocionando aún hoy día. En Giotto, el paisaje ya no es meramente un signo, sino que hay una intencionalidad de integración de las figuras con un medio geográfico y una mayor coherencia y realismo en la reproducción del mismo.

\footnotetext{
${ }^{114}$ Giotto fue el artífice de la revolución en la pintura italiana, que marcó el rumbo que ésta seguiría durante los siglos siguientes. Abandonó la manera bizantina (maniera greca) de sus predecesores, con sus superficies planas y etéreas, y adoptó un lenguaje latino, que retornó al gusto por las formas naturales. Su estilo fue totalmente innovador, superando a su maestro Cimabue y a los otros pintores de su época. Dante refiere en la Comedia: "Creía Cimabue en la pintura/tener el campo, que ahora es mantenido/por Giotto, que su fama vuelve oscura." (Purgatorio XI: 94-96).

${ }^{115}$ Entre 1397 y 1399, Giotto pintó los frescos sobre la vida de san Francisco en la Basílica de Asís. La iconografía muestra a san Francisco en su aspecto de amante de los pobres y de la naturaleza, en una innovadora manera plástica de manifestar el amor de Dios por sus creaturas.
} 


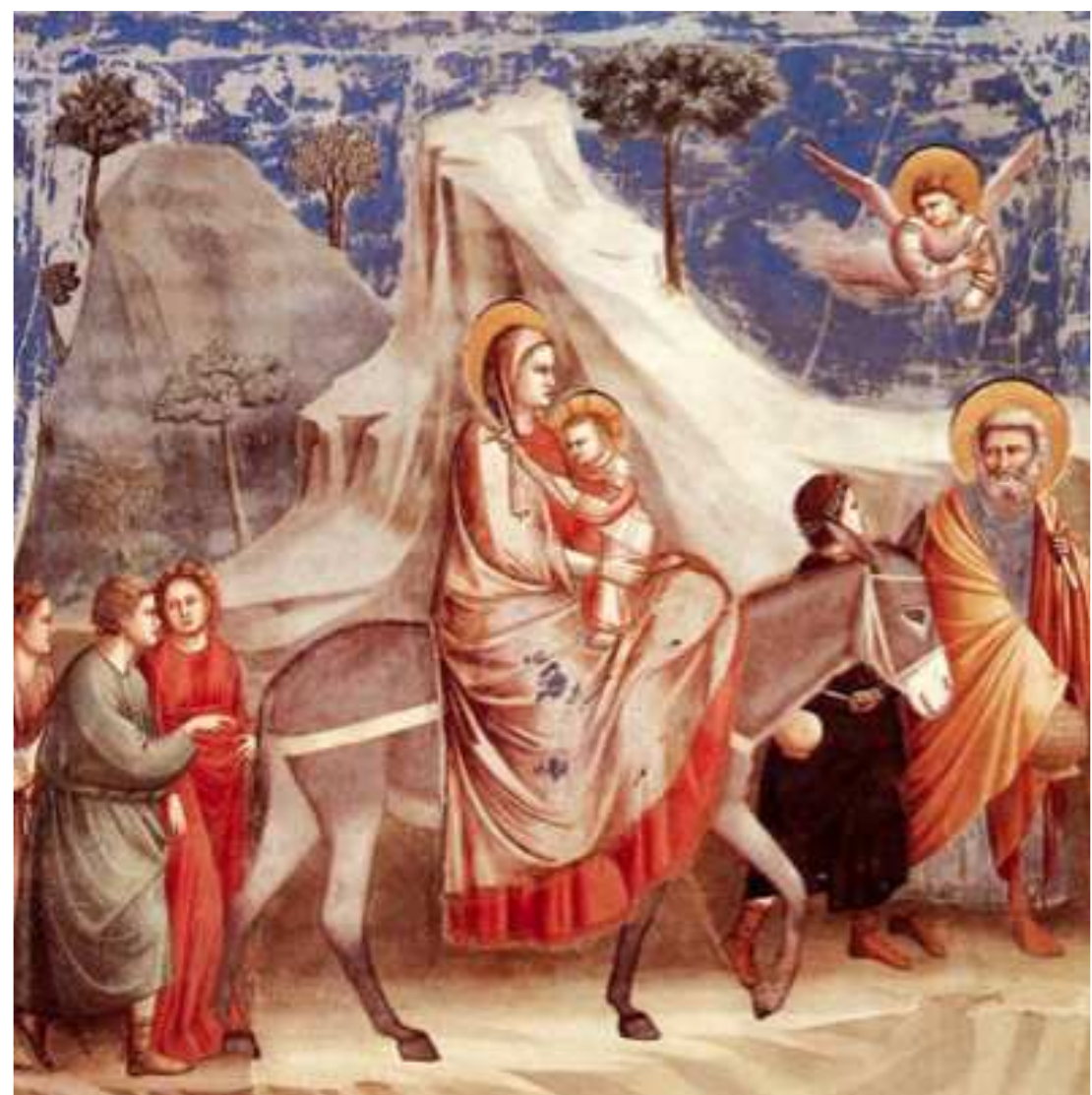

Fig. 13. GiotTo, La Huida a Egipto, 1303-1306, fresco. Capilla Scrovegni, Padua. Foto tomada de Corrain, 2002, p. 48.

En su fresco de la huida preceden la marcha San José y Jacobo, quienes intercambian miradas de preocupación. El adolescente lleva una corona de hiedras, símbolo tanto de amistad y fidelidad (debido a que la planta se adhiere firmemente a su soporte), como de vida eterna (porque sus hojas son siempre verdes). Tres jóvenes cierran el cortejo: la partera Salomé y dos muchachos con los que conversa apaciblemente. Los ropajes son los que usaba a principios del Trecento la gente del pueblo. La túnica era la misma para hombres y mujeres y se diferenciaban en la forma de usarla. Los hombres tenían mangas amplias en su parte superior y levemente angostadas en las muñecas, y la llevaban más corta, ajustada en la cintura. Calzaban un tipo de botas, los stivali, que se utilizaban en Italia desde del siglo XII; eran suaves y estrechas, adecuadas para las caminatas. Las mujeres usaban las túnicas ajustadas y ceñidas debajo del busto con un cinto.

En el centro de la escena están los verdaderos protagonistas, la Virgen y Jesús. María semeja una matrona romana, se encuentra perdida en sus pensamientos, y su rostro trasluce angustia. En ese momento es sólo una madre acongojada que espera salvar a su hijo. Aislada física y espiritualmente del resto, su mutismo contrasta con la actitud comunicativa de los demás personajes. Giotto refleja con verismo y sensibilidad el ambiente de tribulación y sigilo propio de un viaje de escape. Los tres 


\section{Patricia GRAU-DieCKMAnN, Representaciones de los viajes de la Sagrada Familia}

conjuntos de personajes son reflejados en sus distintas y previsibles reacciones: los jóvenes charlan, pero su actitud es cautelosa; el hombre a cargo de la expedición encuentra apoyo moral en el hijo juicioso; la madre sólo piensa en su hijo. Cada persona vive su experiencia personal independiente del resto de la comitiva. Cada rostro, cada expresión son únicos e individualizados.

Es una familia humana viviendo un drama terreno, la sacralidad sólo está insinuada por los halos, escorzado en el caso de María. Sorprende que José esté nimbado, iconografía nueva que indica que su persona está paulatinamente cobrando un nuevo protagonismo e interés como padre nutricio de Jesús, debido a la influencia de las órdenes dedicadas a la Virgen y a los predicadores populares. El espectador observa y compadece, no se encuentra fuera de la escena, es parte de la misma, pero sabe algo que los viajeros no conocen: un ángel los cuida y protege. Llegarán a salvo.

Las figuras son contundentes y con peso, ubicadas en un espacio ilusionista convincente. La monumentalidad de esta pintura está dada no por sus dimensiones, sino por la majestuosidad de las formas simples, pero amplias, de los personajes vigorosos, sólidos y corpulentos. El artista invita a abarcar con una sola mirada la totalidad de la imagen, asistido por el fuerte agrupamiento de las figuras y la limitada profundidad del "escenario", en el que se destacan dos peñascos con árboles. A pesar del verdor, el paisaje no deja de ser árido y frío, lejos de la voluptuosidad y exotismo de Egipto. Giotto sugiere que aún tienen un largo camino por recorrer hasta llegar al refugio.

La simplicidad de medios que Giotto usa para la narración no tiene rival en la pintura, es una historia relatada con imponente ternura y conmiseración hacia el componente humano de la doble naturaleza de Cristo. El numeroso grupo familiar refleja la realidad de las prolíficas familias italianas de la época. En un ámbito educado como era el de los Scrovegni, la necesidad de identificación con la Sagrada Familia y sus allegados era tan real como para el pueblo común, compatibilidad que se refuerza por el uso de los ropajes contemporáneos.

\section{La Maestà de Duccio di Buoninsegna}

La Maestà de la catedral de Siena (Fig. 14), con la imagen de la Virgen entronizada, patrona y abogada de la ciudad, forma parte de un políptico compuesto por varios paneles de madera pintados por Duccio di Buoninsegna (c. 1255-1319), única obra firmada por el maestro ${ }^{116}$. Duccio sustituyó con su Madonna a una imagen anterior sumamente milagrosa ${ }^{117}$, pero de menor tamaño, y le agregó un

\footnotetext{
${ }^{116}$ Los paneles fueron desmontados y tuvieron distintos destinos, pero la mayor parte se encuentra actualmente en el Museo dell'Opera de Siena.

${ }^{117}$ En 1311 una solemne procesión recorrió las calles de Siena, Italia: “(...) Y aquel día en que se llevó al Duomo, se cerraron los negocios y ordenó el obispo un cortejo grande y devoto de sacerdotes y frailes en una solemne procesión, acompañada por los señores 'Nove' y por todos los oficiales de la Comuna y todo el pueblo y poco a poco todos ellos se acercaban a la Tabla con antorchas en las manos y luego a la derecha las mujeres y los niños con mucha devoción y
} 
compendio de escenas sobre las vidas de la Virgen y de Cristo en el verso y en el recto de la tabla ${ }^{118}$.

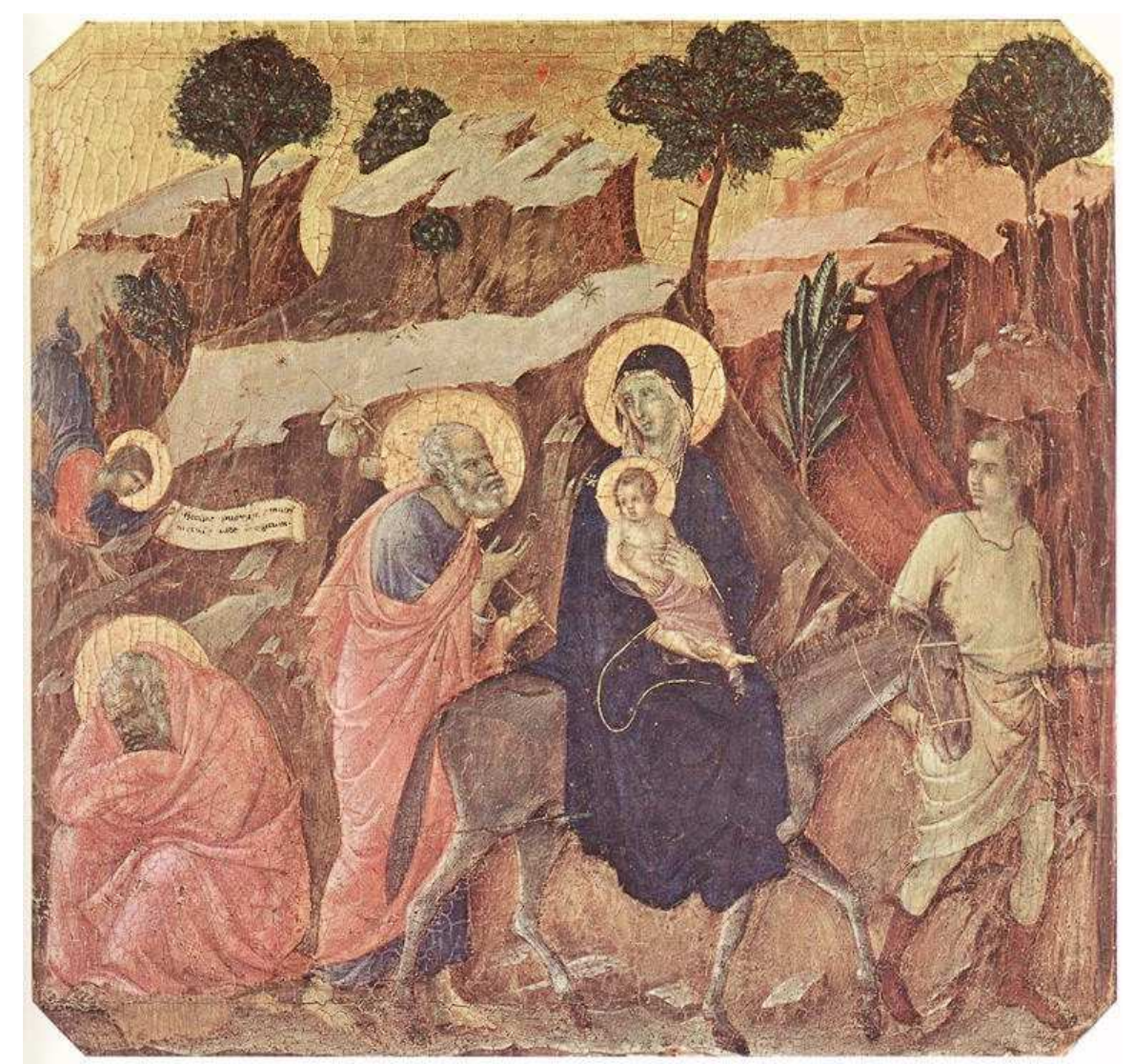

Fig. 14. DuCCiO Di BuOninsegna, La Huida a Egipto, Predela de La Maestà, pintura sobre tabla, 1308-1311, Museo dell'Opera del Duomo, Siena,. Foto tomada el 1/12/2012 de http://www.terminartors.com/artworkprofile/Duccio_di_Buoninsegna

La predela del recto alterna acontecimientos de la infancia de Jesús con representaciones de profetas que prefiguran tipológicamente sucesos del Nuevo Testamento. Allí pintó una huida con dos escenas en el mismo panel: a la izquierda San José recibe en sueños el aviso del ángel, que porta una filacteria en la que se lee "Accipe puerum et matrem eius et fuge in Egyptum" (Mt 2,13). Sin solución de continuidad, en la prolongación del mismo paisaje rocoso de la escena anterior, está la Sagrada Familia, con Jacobo encabezando el grupo. El artista ha indicado de esta manera la secuencia temporal de dos acontecimientos sucesivos, que debieron

acompañaron la mencionada Tabla hasta el Duomo, haciendo la procesión en torno del Campo, como se acostumbra, sonando todas las campanas a gloria, por devoción a tan noble tabla como ésta. La mencionada tabla fue hecha por Duccio di Niccoló pintor (...).” (G. MiLANESI, 1854: 169, en Teorías y Realizaciones..., 1977: 149).

${ }^{118}$ La tabla de la Maestà mide $2,14 \mathrm{~m}$ por 4,10 m. Las escenas de la predela miden 42,5 por $44 \mathrm{~cm}$, y los profetas 42,5 por $16 \mathrm{~cm}$. 


\section{Patricia GRAU-DieCKMANN, Representaciones de los viajes de la Sagrada Familia}

acaecer en circunstancias y espacios diferentes, amalgamándolos en una representación plástica unitaria ${ }^{119}$. En el panel que sigue a la fuga está Oseas, el profeta del siglo VIII a.C., que reveló la caída del reino de Judá a manos de los asirios. En el rollo que sostiene se lee "Ex Egypto vocavi filium meum" (Oseas $11,1)$, frase ya citada, a la que recurre Mateo como preanuncio de la huida a Egipto. Las escenas del políptico seguramente eran utilizadas como ayuda-memoria e ilustración para la enseñanza de la historia sagrada, avalando la famosa sentencia gregoriana "(...) lo que las escrituras son para los educados, las imágenes son para los ignorantes" $"$.

\section{La Borgoña: Melchior Broederlam}

Durante el siglo XV la corte de Borgoña se vio inundada por escultores, pintores y joyeros flamencos que trabajaban para Felipe el Atrevido. Entre ellos se encontraba Melchior Broederlam (activo entre 1381 y 1410), a quien se le encomendó en 1390 la pintura de dos paneles en la parte posterior de las alas exteriores del frente de altar tallado por Jacques de Baerze para la Cartuja de Champmol, que podían apreciarse cuando el retablo se cerraba y quedaba a la vista un díptico con la Anunciación y la Visitación a la izquierda y la Presentación en el Templo y la Huida a Egipto a la derecha (Fig. 15) ${ }^{121}$.

Broederlam trabaja el detalle como si se tratara de una miniatura agrandada, y no de una pintura a gran escala, plasmada en tablas de $1,50 \mathrm{~m}$ de alto por 1,25 $\mathrm{m}$ de largo cada una. Las arquitecturas, los mosaicos del piso, la disposición de los pliegues y la espacialidad que logra por las sucesivas diagonales del camino zigzagueante que lleva hacia el castillo coronado con torres almenadas en la cima de un monte rocoso son algunos de los indicios de la influencia italiana que recibió Broederlam. Los castillos que están representados en ambos paneles no han sido asimilados a arquitectura alguna de existencia real ${ }^{122}$.

En cuanto a los temas ilustrados, cabe señalar que en el ala izquierda (Anunciación, Visitación) las escenas son anteriores al nacimiento de Jesús, y en el de la derecha, ya ha nacido. En este sentido, el mensaje teológico de esperanza que se abre a la humanidad con la llegada de Cristo tiene su correlato visual en el acceso al castillo, vedado en la montaña de la Visitación por la inexistencia de un camino, y accesible mediante una senda en el panel derecho que ilustra episodios con el Mesías ya encarnado. El castillo almenado es además una referencia a la pureza de

\footnotetext{
${ }^{119}$ Duccio di Buoninsegna permaneció fiel a una tradición bizantina que se iba desvaneciendo y que se evidenciaba principalmente en el uso de fondos dorados, pero la suya es una manera propia, pletórica de elegancia y gracia, que reinterpreta el modo ítalo-oriental. Su destreza en la ilustración de los detalles indica una calidad afín al estilo estético de los miniaturistas flamencos.

${ }^{120}$ SAN GREGORIO MAGNO (540-604), Epístola XI, 13. PL 77,1128c.

${ }^{121}$ El díptico se exhibe actualmente semiabierto en el Museo de Bellas Artes de Dijon y es el ejemplo más temprano existente de pintura en estilo franco-flamenco.

${ }^{122}$ Información provista por Mme. Dominique Bardin, Documentalista del Museo de Bellas Artes de Dijon, el 04/11/2009.
} 
María, y sus torres, una metáfora de la vigilancia de la fuerza espiritual, la firmeza en la fe y la dignidad de Madre de Dios de la Virgen María. Turris Davidica es uno de los títulos de María que le atribuye Honoré d'Autun († c. 1135), imagen tomada del Cantar de los Cantares 4, 4: "Como la torre de David tu cuello, edificada como fortaleza". Otro de los atributos marianos aquí aludidos es la castidad perpetua de María, simbolizada por la fuente del primer plano. El agua es una alusión al aliento espiritual, a la salvación y a la vida eterna. A María se la llama "fuente de jardines, manantial de agua viva" y "manantial de la vida"123.

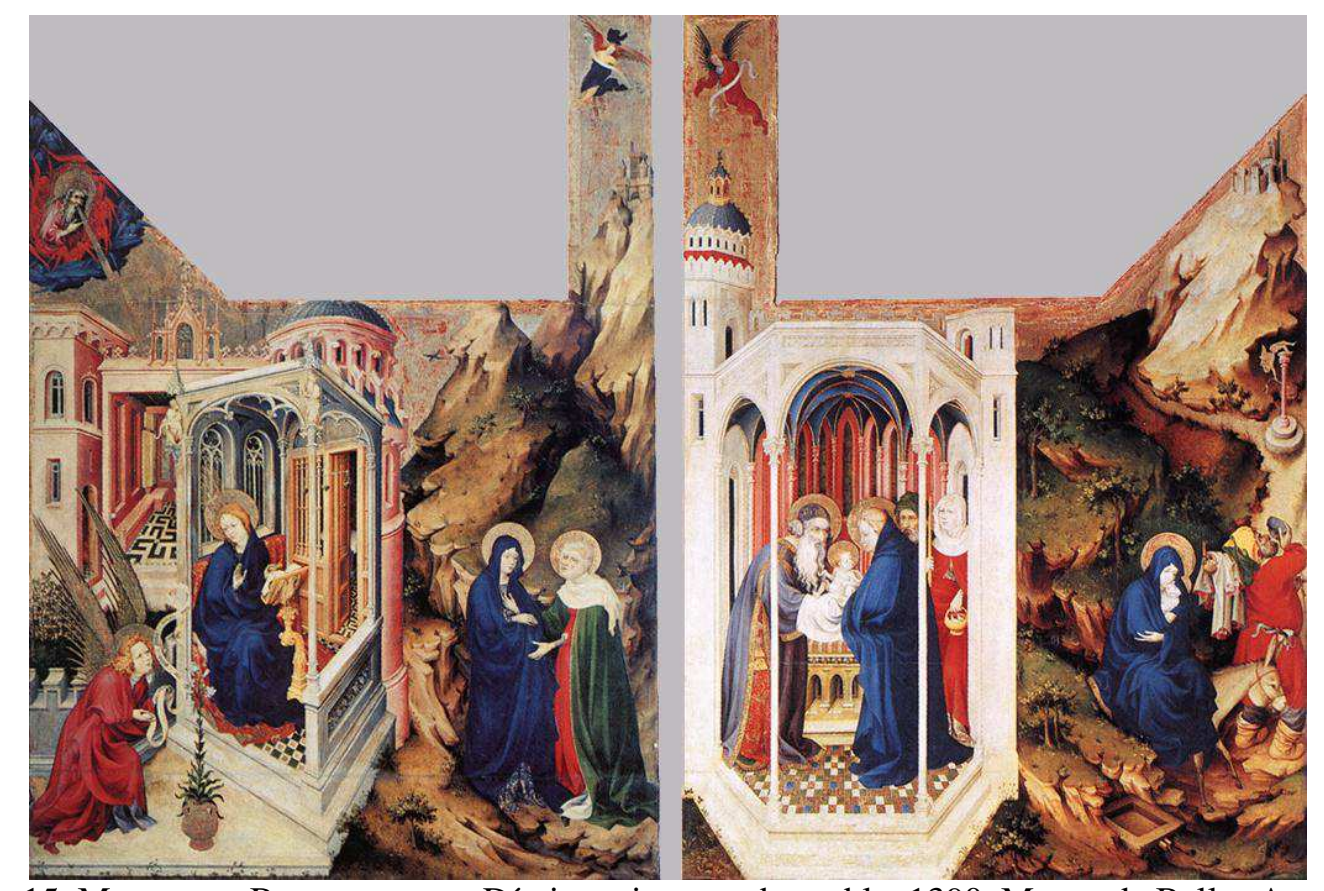

Fig. 15. MELCHIOR BROEDERLAM, Díptico, pintura sobre tabla, 1390, Museo de Bellas Artes de Dijon, Francia. Foto tomada de http://www.friendsofart.net/en/art/melchior-broederlam/the-dijonaltarpiece el 30/11/12.

Al pie del monte hay un ídolo que se desploma, ilustración que se basa en las frecuentes referencias de los textos apócrifos a las efigies paganas que se derrumban ante el paso de la Sagrada Familia, y que muy a menudo complementa las escenas de la huida:

"Y, en el mismo instante en que habló Jesús, el suelo tembló, y toda la armazón del templo se desplomó de arriba abajo. Y el ídolo de Apolo, los sacerdotes del santuario y los pontífices de los falsos dioses, quedaron sepultados en el interior del edificio, y perecieron" ${ }^{\text {"124 }}$.

${ }^{123}$ Cantar de los Cantares 4, 15 y Salmos 36, 8, respectivamente.

${ }^{124}$ Evangelio Armenio de la Infancia, XV:16. 


\section{Patricia GRAU-DiECKMANN, Representaciones de los viajes de la Sagrada Familia}

Los templos griegos, en especial los dedicados a Apolo, se ubicaban en lo alto de un camino zigzagueante, que permitía diferentes vistas del santuario a medida que los fieles ascendían ${ }^{125}$. Curiosamente, una similar disposición muestra el castillo, ubicado en lo alto de un abrupto camino serpenteante que asciende por la rocosa y escarpada montaña en esta tabla de Champmol.

La manera en que la familia es representada por Broederlam en la fuga responde a una nueva forma de religiosidad, que se manifiesta principalmente en los Países Bajos, una "plebeya familiaridad con que se trataba a Dios en la vida diaria"126, y que se expresa mediante el incremento de representaciones realistas. De hecho, la sacralidad de Jesús y su Madre no es explícita y poco se diferenciaría de una familia de aldeanos en viaje, si no fuera por los halos de ambos. No llevan vestidos lujosos; ni siquiera el Niño - cuya riqueza de ropaje es tradicional— luce gala alguna. Esta llaneza en el trato con lo sagrado se refleja principalmente en la figura de José, que se presenta como un auténtico campesino flamenco, que toma agua o vino de su cantimplora mientras lleva de la brida al burro, postura que denota la fijación iconográfica de su ridiculización en los misterios. Se revela como un bonachón hombre de pueblo, preparado para el viaje: lleva una vara de la que pende descuidadamente su capa, un pequeño talego para monedas asegurado al cinturón, el sombrero de peregrino con los bordes doblados hacia arriba, toscas botas de caminante y el tonelillo con líquido. Preocupado por calmar su sed, está ajeno al idilio de miradas que, en intimista escena, sostienen el Niñito Dios y su Madre.

Broederlam presenta una iconografía que recurre a los símbolos marianos, a los textos apócrifos y a la traducción en imágenes de la tendencia religiosa contemporánea. Hay una sutileza culta en la elaboración metafórica que combina textos pseudoepigráficos con textos sapienciales veterotestamentarios.

\subsection{Los libros de horas}

En la segunda mitad del siglo XIII había aparecido en Inglaterra un tipo de libro que ocupará una muy buena parte de la producción de manuscritos de los siglos siguientes, el Libro de Horas, manual de oraciones destinado a la devoción privada con importantes ilustraciones que acompañan al texto. Se difundirá por toda Europa y a partir del siglo XIV se convierte en un objeto de lujo, y será una pieza ineludible y valiosa del ajuar de toda dama de abolengo.

Suntuosamente decorados, los libros de horas serán verdaderos tesoros al alcance sólo de personajes regios o grandes señores. Ineluctablemente se ilustraban

\footnotetext{
${ }^{125}$ El culto a Apolo fue introducido en Egipto por Alejandro Magno, a quien se le atribuye la construcción de un castillo que alojó a la Sagrada Familia en El Cairo: "Y partidos de allí, llegaron, cerca de las fronteras de Egipto, a una ciudad que se llama Cairo, y moraron en un gran castillo de la residencia real, edificio cubierto, en un vasto espacio, por palacios y por fortalezas. Era un castillo magnífico, muy elevado, adornado espléndidamente y decorado con gran variedad, que Alejandro de Macedonia había levantado otrora, en los días de su mayor poder." (Evangelio Árabe de la Infancia, XV).

${ }^{126}$ HuIZINGA, 1993: 219.
} 


\section{Patricia GRAU-DiECKMANN, Representaciones de los viajes de la Sagrada Familia}

fragmentos de los cuatro evangelios y se incluían los diversos oficios: de la Virgen, de la Crucifixión, del Espíritu Santo, de los difuntos, etc. El más ricamente ilustrado era el de las horas de la Virgen, y para cada hora canónica correspondía una miniatura fija. Los Maitines se representaban con escenas de la Anunciación; los Laúdes, de la Visitación; la Prima con la Natividad; la Tercia se ilustraba con la Anunciación a los Pastores; la Sexta correspondía a la Epifanía; la Nona era la Presentación en el Templo, y las Vísperas se ilustraban invariablemente con la Huida a Egipto. La última hora, las Completas, que se rezaba ya entrada la noche, era variable y podía representarse con la exaltación post-mortem de la Virgen, su Coronación, Entronización, etc.

Otra sección era el Calendario. Cada mes, ilustrado en forma de signo zodiacal, era representado junto con la faena más característica de esa época del año ("los trabajos y los meses"). Debido a que la de Vísperas era una sección fija e ineludible en los libros de horas, las escenas de la fuga a Egipto se multiplican y enjoyan gracias a estos libros, que invaden el ámbito no religioso y que son producidos por talleres laicos.

\section{Libro de Horas del Mariscal de Boucicaut}

A comienzos del siglo XV el Mariscal de Boucicaut ${ }^{127}$ encargó para él y su esposa, Antoinette de Beaufort, un libro de horas que actualmente se encuentra en el Museo Jacquemart-André, en París ${ }^{128}$. Si bien al autor de las iluminaciones se le conoce sólo como "el maestro de Boucicaut", es probable que se trate del pintor de Brujas Jacques Coene, establecido en París alrededor de 1398. El libro presenta ilustraciones ${ }^{129}$ a toda página, sin texto, inscriptas en un doble marco, cuyas líneas rectas se avienen a las discretas decoraciones florales, ramitas de hiedra, y viñetas con elementos vegetales, que los rodean ${ }^{130}$.

${ }^{127}$ Conocido como el Mariscal de Boucicaut, Jean II le Meingre nació en 1366 en Yorkshire, condado al noreste de Inglaterra, y murió en 1421. Fue un hombre de vida ejemplar y piadosa que hizo de los ideales de la caballería un estilo de vida, siendo él mismo un eximio combatiente en torneos. Fundó la orden Dame Blanche à l'Écu Vert (Blanca Dama del Escudo Verde), cuyo fin era proteger a las damas allegadas de caballeros ausentes.

${ }^{128}$ Es el ms.2, que mide 27,5 por $19 \mathrm{~cm}$, y fue realizado hacia $1410-1415$.

${ }^{129}$ Hay discrepancia con respecto al número de folios ilustrados. De Hamel (2000: 191) menciona 44; Walther y Wolf (2005: 269) mencionan 46; y el Catálogo de la Exposición de 1954 en la Biblioteca Nacional de Francia (Les manuscrits... , 1955: 97) contabiliza 45 iluminaciones.

${ }^{130}$ Esta sobria decoración marginal contrasta con otros libros miniados contemporáneos, cuyos marcos están poblados por aves, flores, hojas, mariposas, abejas y otros insectos pintados con vívido realismo. De Jacques Coene se sabe que era un eximio conocedor de pigmentos y que aplicaba la matemática a sus prácticas pictóricas. Estas técnicas se evidencian en la ejecución de este manuscrito y han servido para atribuirle su autoría (TOLLEY, 1993). Una de sus características es la preferencia por el uso frecuente del bermellón, el verde y el azul de ultramar, así como la generosidad en la aplicación de la pintura de oro, razón de sus deslumbrantes soles o estrellas, cuyos rayos consisten en finos trazos individuales. En las decoraciones marginales también abunda la pintura de oro. 


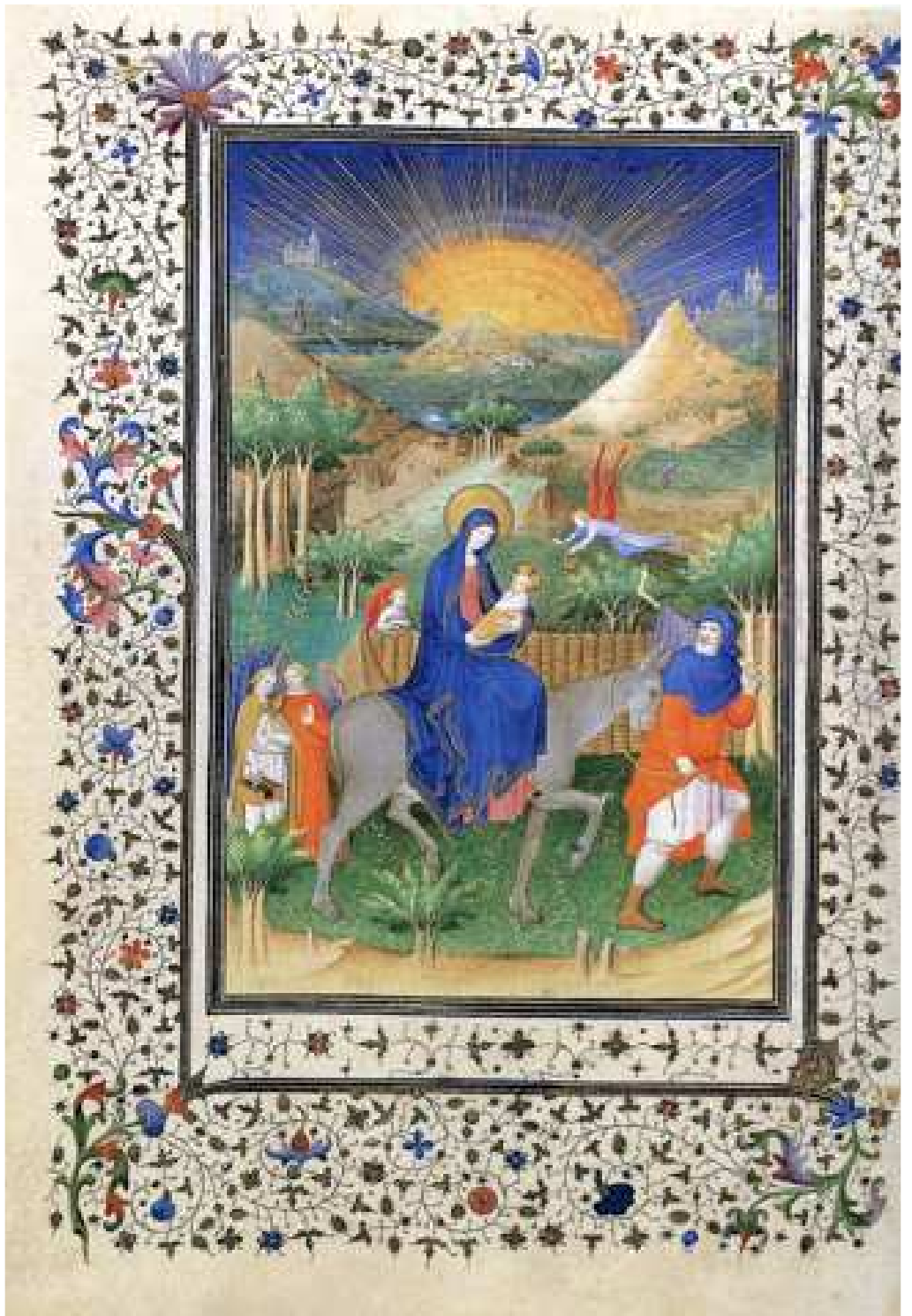

Fig. 16. Libro de Horas del Mariscal de Boucicaut, códice miniado, 1410-1415, Museo Jacquemart-André, París, Francia. Foto tomada de http://www.flickr.com/photos/24364447@N05/6695168681/ el 1/12/2012.

En el folio 90v hay una huida sumamente poblada (Fig. 16), en la que el despliegue de la naturaleza ocupa casi la mitad de una composición que se extiende en profundidad y en lejanía, en un innovador tratamiento del paisaje por parte del Maestro de Boucicaut. La difuminación del cielo y la tierra hacia el horizonte son concordes con el conocimiento de los colores que poseía Coene. Una incipiente perspectiva aérea permite observar, en los planos posteriores, diferentes escenas laborales, pero existe un cierto desfase de tamaños entre los hombres, los edificios y los niveles espaciales.

Una técnica a la que recurre a menudo el pintor es presentar una curvatura en el límite inferior de las escenas, muy cercano al borde, lo que da al observador la 


\section{Patricia Grau-DiecKmann, Representaciones de los viajes de la Sagrada Familia}

ilusión de un espacio convexo que se amplía hacia el horizonte. Hay una irrupción generosa de los elementos naturales en toda la escena. La vida bulle y las actividades cotidianas del día acaban de comenzar. Hay villorrios, fincas, trabajadores ensimismados en sus labores, cisnes nadando en un lago ${ }^{131}$, segadores $\mathrm{y}$, en el centro lejano superior de la escena, bajo ese magnífico y generoso sol, un pastor cuida sus ovejas, como alegoría profética de que ese niñito en brazos de su madre será un día pastor de los hombres a los que vino a redimir.

El sol descomunal obliga a la reflexión: incluso las más negras noches se desvanecen con los primeros rayos de luz. Es el cristianismo que surge e ilumina las vidas de sus fieles, dejando atrás miedos e incertidumbres. Una cerca separa a la familia del resto de las escenas. Podría ser una referencia al hortus conclusus, que se refiere a la virginidad de María, inspirado en el Cantar de los Cantares 4,12: "Jardín cerrado eres, hermana mía, esposa mía; fuente cerrada, sellado manantial". Los acompañantes son ángeles, portan viandas, los vigilan, o juntan pequeños frutos rojos del jardín en una cesta. Parecerían ser cerezas, uno de los árboles del Paraíso que, debido a la abundancia de su cosecha, es un símbolo de la vida eterna ${ }^{132}$. La situación es distendida, afable, sin connotación de peligro. La vida real y cotidiana del siglo XV también comienza a ser amable para todos.

La disposición de la familia y los ángeles que los acompañan recuerda a la Huida de Giotto de la Capilla Scrovegni: hasta las poses y la gestualidad son similares. Pero, si bien el Maestro de Boucicaut pinta una recreación no convencional de la fuga, no hace alusión alguna a textos apócrifos, sino a una fuente canónica y erudita del Antiguo Testamento, como es el Cantar de los Cantares. Si en Giotto su característica es la recurrencia a fuentes no ortodoxas, y la libertad creativa que le permite expresar pictóricamente el auténtico clima que debió vivirse en la huida, el Maestro de Boucicaut recrea formalmente la imagen de Giotto, pero desecha toda alusión a los evangelios pseudoepigráficos, y deliberadamente recurre a una iconografía oficial e instruida, interesado en reflejar la realidad ya no tan dura y agobiante para el hombre común, que encuentra placer y solaz en sus obligaciones cotidianas.

\section{Las Muy Ricas Horas del duque de Berry}

Conocido como "el rey de los manuscritos iluminados", Las Muy Ricas Horas del duque de Berry, es estimado como una de las obras cumbre en la historia de la pintura $^{133}$.

\footnotetext{
${ }^{131}$ El cisne es un elemento constante en las miniaturas de exteriores de Coene. Al parecer, se trataba de su animal favorito y busca incluirlo en todas las escenas de paisajes.

${ }^{132}$ SILL, 1987: 55.

${ }^{133}$ Este Libro de Horas, de azarosa trayectoria, permaneció perdido e ignorado durante tres centurias hasta que a mediados del siglo XIX un erudito descubrió un códice cuya encuadernación en cuero rojo databa del siglo XVII y ostentaba las armas de una familia genovesa. Inesperadamente, en el folio correspondiente al mes de enero, presidiendo la escena del banquete, se reconoció al hijo del rey Juan el Bueno: Jean, duque de Berry. Allí estaban, al igual que en
} 


\section{Patricia GRAU-DiECKMANn, Representaciones de los viajes de la Sagrada Familia}

Hijo, hermano y tío de reyes, Jean de Berry nació en 1340 y su corte en Bourges fue la más brillante de su época en Francia. Amante de las artes, coleccionaba tapices, orfebrería, pinturas y manuscritos iluminados. Atrajo a numerosos artistas y les encargó variadas y bellísimas obras, entre ellas Las Grandes Horas del duque de Berry; Las Pequeñas Horas del duque de Berry, Las Muy Ricas Horas del duque de Berry y Las Bellas Horas del duque de Berry.

Sus iluminadores favoritos, los hermanos Herman, Pol y Hennequin Malouel conocidos como "los hermanos Limburgo" por su lugar de origen- pintaron 71 de las 129 miniaturas de Las Muy Ricas Horas... entre 1413 y $1416^{134}$. Inconcluso por la muerte de todos los involucrados, el libro pasó ocasionalmente a manos del duque Carlos I de Saboya, quien mandó completar los folios faltantes unos setenta años después de las primeras iluminaciones. Estas miniaturas posteriores mostraban una factura totalmente diferente a la de los Limburgo, y fue posible atribuir su autoría a un pintor residente en Bourges, Jean Colombe ${ }^{135}$, gracias a la similitud con pinturas del Apocalipsis figurado de los duques de Saboya, del Escorial ${ }^{136}$. Entre 1428 y 1435 Jean Bapteur y Péronet Lamy pintaron algunas de las miniaturas del Apocalipsis, y en 1482, el duque Carlos de Saboya contrató a Colombe para terminar el libro ${ }^{137}$.

Ante el desafío que significaba competir con las elegantes y frágiles figuras de los tres hermanos Limburgo (destacados representantes del estilo gótico internacional), Colombe optó por reflejar el espíritu de su propio tiempo en vez de intentar revivir el pasado. Tras siete décadas el estilo, el sentido estético y los intereses habían cambiado. Se alejó totalmente del carácter de los Limburgo no sólo en la forma de representar personajes, arquitectura y paisajes — con menos detalles, entre otras cosas-, sino también en la manera de pintar y de aplicar los pigmentos ${ }^{138}$.

diversas páginas, los escudos de armas del duque, osos y cisnes heridos que en francés (ours, oso y cygne, cisne) forman el juego de palabras Ursin, uno de los santos patrones de Bourges, la capital del duque. En base al inventario de los bienes del duque tras su muerte en 1416 - probablemente de peste-, se determinó que se trataba de lo que probablemente fuera la más valiosa obra de arte pintada para Jean, Las Muy Ricas Horas del Duque de Berry. Tras deambular por Saboya, los Países Bajos e Italia, el manuscrito regresó a Francia, y hoy en día está alojado en el Museo Condé de Chantilly, donde es considerado uno de los más preciados tesoros artísticos que componen el patrimonio del museo (Ms. 65. Sus medidas son 29 por $21 \mathrm{~cm}$ ).

${ }_{135}^{134}$ Los tres murieron de peste el mismo año que el duque.

${ }^{135}$ La autoría fue establecida por Paul Durrieu (1855-1925), especialista en manuscritos y Conservador del Departamento de Pinturas del Museo del Louvre.

${ }^{136}$ Ms. Vitr. 1, Biblioteca Real del Monasterio, El Escorial. Medidas 26,2 por 41,5 cm.

${ }^{137}$ Un documento del archivo del duque señala el pago de 25 escudos de oro a Jean Colombe en 1485 "in villa de Bourges, pro illuminatura et historiatione certarum horarum canonicarum" (LONGNON, 1989: 24).

${ }^{138}$ Sus colores son más brillantes y profundos; el resultado no es una superficie homogénea, ya que logra el modelado de las figuras mediante la aplicación de pequeñas líneas paralelas, visibles a simple vista, dando la impresión de una cierta rugosidad. Recurre al dorado para la iluminación y sus colores predominantes son el rojo y el azul. 


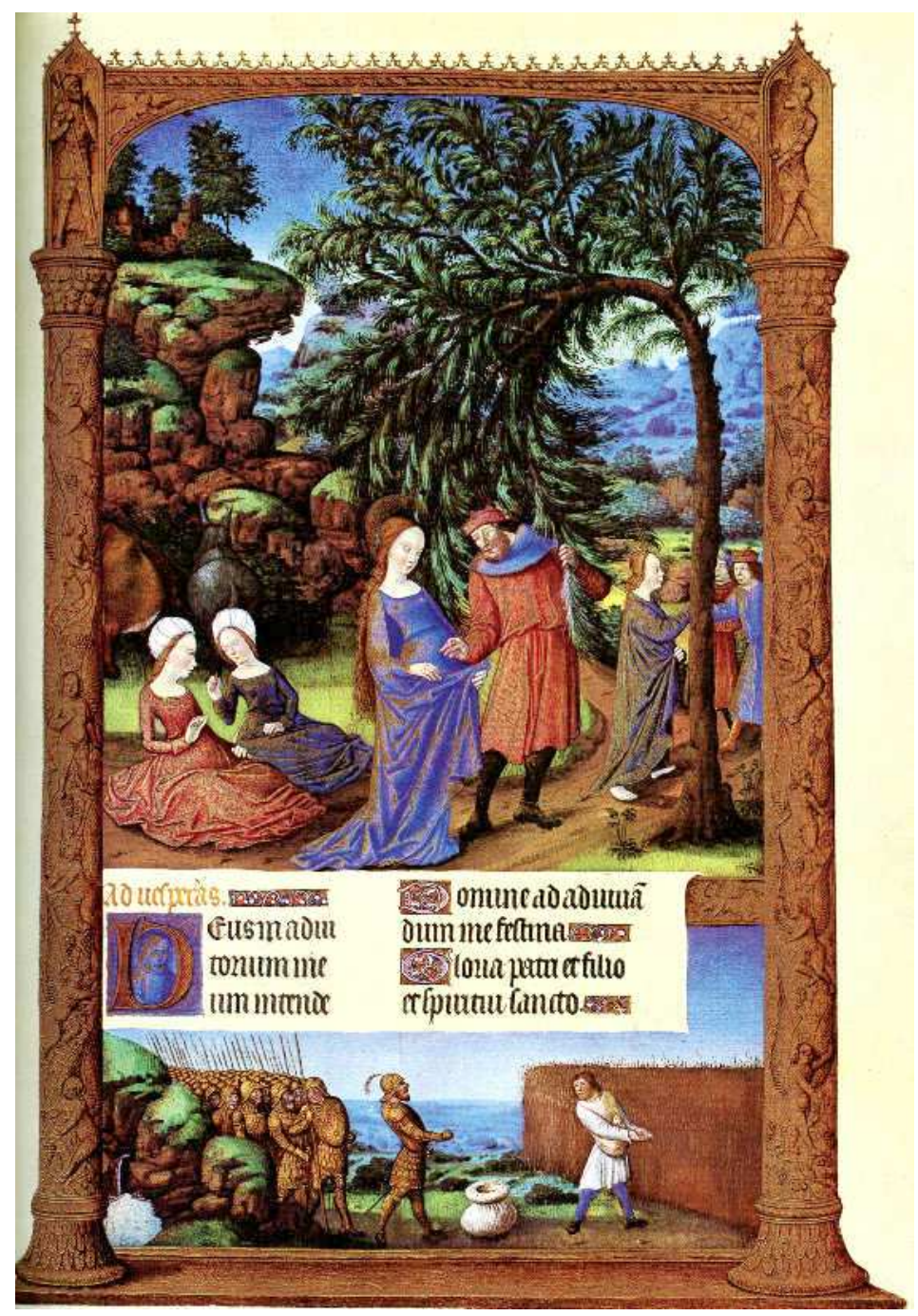

Fig. 17. Las Muy Ricas Horas del duque de Berry, miniatura pintada por Jean Colombe, c. 1485, Museo Condé, Chantilly, Francia, códice miniado. Foto tomada de http://www.christusrex.org/www2/berry/f57r.html el 30/11/2012.

En el folio 57r Colombe pintó un Descanso en la Huida (Fig. 17), que es la única escena de las Horas de la Virgen en la que no hay participación alguna de los Limburgo. La miniatura es a toda página y está enmarcada a ambos lados por columnas con amorcillos en grisalla. Ilustra dos escenas separadas por el texto: en la parte inferior se representa la leyenda del campo de trigo, que generalmente forma parte del paisaje de fondo en los descansos y que aquí cobra especial relevancia como motivo autónomo. La escena superior ilustra el Reposo en la Huida, en la que José alcanza a María casi niña — sin velo y con el cabello suelto- unos pequeños frutos marrones, que recoge de un árbol que se inclina. La Virgen junta los mismos en un pliegue de su túnica. El Niño Jesús, muy crecido, parece hablarle al árbol milagroso. Dos elegantes jóvenes sentadas en el piso, con vestidos y tocado en boga, conversan y comen esos frutos. 


\section{Patricia GRAU-DiECKMANn, Representaciones de los viajes de la Sagrada Familia}

Es en esta época cuando surge el criterio de "moda" como actitud estética de pertenencia a un cierto grupo, y por ello cobra particular importancia la decisión de Colombe de mostrar el gusto y la vestimenta contemporáneos. Las mujeres llevaban una túnica con cola que levantaban para caminar, formando pliegues al sostenerla sobre su vientre con la mano izquierda. Las frentes femeninas abombadas, que pueden apreciarse en esta ilustración, eran consideradas un signo de belleza. Dos figuras masculinas, probablemente lugareños, se aproximan por el camino, ostentando los rasgos que caracterizan a Jean Colombe: son personajes robustos y más bien de baja estatura, con los rasgos faciales bastos y poco delicados. Casi mimetizados contra las rocas del paisaje están el buey y el burro. La escena es amable y familiar y, si no fuera por los soldados del campo de trigo de la escena inferior, podría creerse que se trata de un paseo al campo, y no de un apremiante escape.

Por otro lado, también es destacable la importancia como motivo individual de la historia del campo de trigo, que se constituye en excepción plástica. Si bien se incorporará como escena casi costumbrista en los paisajes que sirven de marco a los descansos, su mimetismo con las múltiples tareas campesinas representadas, la hace pasar prácticamente inadvertida.

\section{Árboles milagrosos}

El árbol prodigioso como el aquí representado no sólo brinda sus frutos, las variadas leyendas relatan que produce milagros de curación ${ }^{139}$. Si bien en su versión textual más antigua (el Evangelio del Pseudo Mateo) se trata de una palmera con sus dátiles, posteriores historias mencionan nueces, uvas, guindas, duraznos, naranjas e higos. El Evangelio Árabe de la Infancia menciona al sicómoro, especie de higuera originaria de Egipto, de frutos más pequeños y menos dulces, cuya madera, considerada incorruptible, se utilizaba para fabricar los sarcófagos: "De allí se dirigieron al sicómoro que se llama hoy día Matarieh. Y, en Matarieh, el Señor Jesús hizo brotar una fuente, en que Santa María le lavó su túnica. Y el sudor del Señor Jesús, que ella escurrió en aquel lugar, hizo nacer allí bálsamo.” (XXIV) ${ }^{140}$.

\footnotetext{
${ }^{139}$ El árbol ha tenido un papel preponderante en muchas religiones, no sólo en el tronco judeocristiano. Al respecto, se sugiere la lectura de AUBEL, M..,1884, Histoire et théorie du symbolisme religieux, Librairie de Féchoz et Letouzey, París, Tomo III, cap. XIII; BEIGBEDER, O., 1995, Léxico de los símbolos, Encuentro, Madrid; CHAMPEAUX, G., y STERCKX, D., 1992, Introducción a los símbolos, Encuentro, Madrid; CIRLOT, J., Diccionario de Símbolos, 1995, Labor, Quinto Centenario, Colombia; CROATTO, J., 2002, Experiencia de lo sagrado - Estudio de fenomenología de la religión, Verbo Divino, Villatuerta (Navarra); FRAZER, J., 2004, El folklore en el Antiguo Testamento, Fondo de Cultura Económica, México.

${ }^{140}$ Aunque supuestamente está atestiguado por documentos que el sicómoro original murió de viejo en 1656 (Nota de Ch. Schefer al texto de J. Thenaud, 1884: 55, en AlBERT, 1990, pp. 139-140), todavía se venera allí un retoño suyo, y en este santuario de Matarieh continúan surgiendo las aguas milagrosas. El historiador bizantino Sozómeno escribió en su Historia Eclesiástica (439-450) "En Hermópolis, en la Tebaida, hay un árbol llamado Persis, del que se dice que cura a los enfermos cuando tocan sus ramas, sus hojas y hasta la más pequeña porción de su corteza. Los egipcios
} 


\section{Patricia GRAU-DiECKMANn, Representaciones de los viajes de la Sagrada Familia}

A fines de la Edad Media, el milagro del árbol se había convertido en una escena muy popular. La persistencia temática en la memoria colectiva se debía a la continuada vigencia de las fuentes orales o escritas. Con el tiempo, se revirtió el proceso, la secuencia texto-imagen generó un nuevo ciclo (texto-imagen-texto), que se manifestó en poemas, temas folklóricos, baladas y villancicos, que pasaron a formar parte del acervo popular religioso, en origen de transmisión oral. Fray Ambrosio Montesino ( $†$ 1512/1513) fue un poeta religioso de la corte de los Reyes Católicos. Entre sus obras, ligadas e inspiradas en lo popular, se encuentran estos versos:

Al Destierro de Nuestro Señor para Egipto. Cántase al son que dice: 'A la puerta está Pelayo y llora'
(...) A la Virgen sin mancilla
la verde palma se humilla
en señal de maravilla,
que es del cielo emperadora $(\ldots)^{141}$.

Una versión inglesa del árbol milagroso, el Villancico del Cerezo, es llevada a Estados Unidos de Norteamérica en el siglo XVIII por inmigrantes escoceses, y continúa plenamente vigente como canción navideña hoy en día. Fue publicada en una recopilación de 1892-98 en The English and Scottish Popular Ballads:

José y María paseaban

Por un huerto caminaban

Lleno de guindas y bayas

cuentan que, cuando José huyó con Cristo y María, la Santa Madre de Dios, de la ira de Herodes, fueron a Hermópolis; al atravesar la entrada, este gran árbol, como si no soportara el advenimiento de Cristo, se inclinó hasta el piso y Lo adoró." (V, 21) (Texto en línea: http://www.newadvent.org/fathers/26025.htm, página consultada el 17/07/2009.). Voragine recoge casi literalmente el relato de Casiodoro (c. 485-c. 580) y menciona un árbol que, al igual que el anterior, también se relaciona etimológicamente con el país de Persia, el "persidis", que "cura cualquier enfermedad si uno de sus frutos, o una hoja, o un pedazo de corteza se aplica al cuello del enfermo. Cuando la Virgen bendita huyó a Egipto con su Hijo, este árbol se dobló hasta el piso y adoró con devoción a Cristo." ( CASIODORO, Historia Tripartita, citado por VORAGINE, T. I: 57.). Actualmente el persidis se conoce como persea o viñatigo, su fruto es dulce y sus hojas, ramas y corteza tienen propiedades antinflamatorias, dermatológicas y bactericidas. La medicina proveniente de Medio Oriente, en especial la persa, tuvo durante la Edad Media una merecida reputación. Grandes médicos del medioevo fueron persas (Razes, siglo IX; Avicena, siglo XI), muchos brebajes curativos provenían de Persia, que excedía a los demás centros en cuanto a métodos de destilación y sublimación para la obtención de medicina. Por otro lado, el saber médico que provenía de Grecia fue preservado gracias a los monasterios nestorianos ubicados en el sudoeste de Persia, que establecieron una escuela para la traducción de estos textos griegos de medicina al árabe, evitando así que este conocimiento se perdiera.

141 "Canción a lo divino", Cancionero, 1971, pp. 81-83. 
Rojas como sangre roja. (..)

"Dame una guinda José,

Porque tengo en mí un hijo."

Y entonces habló José

Con palabras despiadadas

"Que te dé la guinda aquél

Que te ha puesto en ese estado."

Y entonces habló el niño

Desde el vientre de la madre

"Doblega el más alto guindo

mi madre comerá algunas" ${ }^{142}$.

En el ámbito popular argentino, un romance tomado del folklore, retoma el tema:

La Virgen va caminando, caminito de Belén.

Como el camino es tan largo, al Niño le ha dado sed.

-Calla, Niño de mi vida, calla, Niño de mi bien,

que allí, adonde vamos, hay un lindo naranjel.

El dueño de las naranjas es un ciego que no ve.

- Ciego, dame una naranja, para el Niño entretener.

- Pase mi señora y corte las que le sean menester.

Como la Virgen es corta no tomaba más que tres.

Una le dio a su Niñito, otra le dio a San José,

y otra quedó en sus manos para la Virgen oler.

Mientras la Virgen cortaba, más volvía a florecer ${ }^{143}$.

Es interesante que pasados tantos siglos, se revalorice plástica y verbalmente la presencia de un árbol milagroso junto a la Sagrada Familia y que, novedosamente, la situación se recree con diferentes variantes, ubicándola en contextos temporales y geográficos indeterminados y universales, como un romance en la corte de los Reyes Católicos, un villancico escocés o inglés conocido por lo menos en el siglo XVIII, y un tema folklórico argentino contemporáneo, seleccionados entre los múltiples ejemplos disponibles. De esta forma, historias que surgieron como necesidades populares para explicar la historia sagrada, regresan a su forma original de relatos básicamente orales.

\subsection{Viajes posteriores al siglo $X V$}

Después del siglo XV, los artistas se volcaron con mayor frecuencia a las representaciones de los viajes de la Sagrada Familia que resultaban menos

${ }^{142}$ The English and Scottish Popular Ballads, № 54 A, recopilada por The Norton Anthology of Poetry, 1970: 40, traducción a versos libres de Daniel A. GRAU-DIECKMANN.

143 "La fe del ciego", Romances..., 1981: 44. 
conflictivas para los fieles, como los reposos y las escenas bucólicas en escenarios idílicos, comiendo frutos alcanzados por los ángeles, que a su vez tocan música y entretienen a Jesús, o con la Virgen dando el pecho al Niño. Los viajes se centraron básicamente en la Huida a Egipto, y los elementos apócrifos, legendarios, simbólicos, alegóricos fueron paulatinamente abandonándose.

El novedoso enfoque postmedieval de la idea del viaje como situación agradable y exenta de peligro condicionó la escena a una escenografía mínima con la Sagrada Familia, un burro y una palmera, que simplemente representaba el paisaje de la tierra faraónica. Su transmisión, creo, continuó siendo principalmente oral, como son las historias que se relatan a los niños como parte de su evangelización. Es probable que el olvido de las historias apócrifas no se debiera a un celo dogmático por mantenerse dentro de la ortodoxia, interés ausente en ese aspecto en los siglos anteriores, sino más bien a la pérdida de un saber público y arraigado en el ámbito doméstico. Paradójicamente, ese conocimiento terminó refugiándose en ámbitos restringidos, bibliófilos.

\section{Conclusión}

La popularidad de las narraciones de los viajes de la Sagrada Familia se debió a que trataban una historia siempre emocionante, describía escenas que podían ser reconocidas fácil y espontáneamente por los devotos fieles, ya que evocaban las peripecias y dificultades — que podían ser muy bien las propias - de una humilde familia como tantas otras. El mensaje de los viajes es válido para todos los cristianos, que pueden reconocerse a sí mismos en ese niño, ese padre y esa madre, con sus temores, sus tribulaciones, e incluso coincidir con ellos en sus momentos de sosiego y descanso. Creo que esta capacidad analógica que transmiten los viajes al permitir la identificación del fiel con la Sagrada Familia, unida a una forma de transmisión básicamente oral, es la que ha facilitado la perduración de narraciones que, como éstas, no enfatizan la grandeza de Dios, sino más bien su vulnerabilidad como hombre.

Los diez siglos que van del $\mathrm{V}$ al XV fueron un largo período, difícil y duro para todos. Los viajes entrañaban siempre un riesgo inesperado. Hombres y mujeres, señores y campesinos, laicos y monjes compartían los arduos tiempos de desasosiego, temores, invasiones, hambrunas, pestes, pero igualmente los de tranquilidad y bonanza. También compartían la creencia en el misterio del Hijo de Dios encarnado entre los hombres. Ese niño débil y dependiente de su Sagrada Madre, que requería la protección de su anciano padre carpintero, guía insustituible en el largo peregrinaje familiar, es una metáfora de contrapeso al Dios sobrecogedor, inmaterial, eterno e ininteligible que agobia al hombre con penurias y exigencias

Las dos facetas del Dios coexistían, aquél todopoderoso al que se recurre con esperanza de alivio, aquél al que se quisiera amparar en su debilidad sobre la tierra. Los artistas de ese entonces asociaban en sus obras las dos presencias, la divina y la humana, en una sola, verdadera y misteriosa. Las asocian tan estrechamente que 
facilitan la comprensión de la simbología teológica tanto para el docto como para el iletrado. Las obras de arte religiosas son el recordatorio de esa Historia Sagrada que no siempre es comprendida intelectualmente, sino más bien intuitivamente, explicada con las palabras de todos los días y forjada en un lenguaje plástico accesible.

Para el devoto profano, las imágenes de los viajes se ven tan verídicas y familiares que probablemente las creyera una copia fiel del mundo que habitaba. El traslado a Belén muestra el acatamiento a las normas del poder imperial. La huida a Egipto remite a las propias esperanzadas fugas campesinas de un dominio a otro, simboliza el ilusionado viaje hacia la salvación. El retorno a Galilea la reincorporación a la comunidad, a la libertad que otorga el sentido de pertenencia. Las representaciones de los viajes son una expresión estética que rescata a los ingenuos hombres de un destino sin gloria. Ellos, con su imaginación, pueden sortear los oscuros destinos que los atormentan.

Los relatos de los viajes de la Sagrada Familia se conservaron a través del tiempo debido a su significado esencial, que se mantuvo incólume a pesar de esas fantasiosas historias que corrían de boca en boca: transmitían el mensaje salvífico que ilusionaba al feligrés. Había un estrecho lazo entre el hombre medieval y su medio religioso, ámbito donde alimentaba su espíritu con esperanzas reales y concretas de salvación. Las imágenes evocadoras de la infancia del Señor lo iluminaban y rescataban de su llana realidad, y le permitían creer en un Dios encarnado y en sus promesas de salvación; lo acercaban al Niño Dios y a su familia. El hombre medieval caminaba también él junto al Niño Dios por los serpenteantes caminos, subía con Él las empinadas pendientes, compartía su sed, apresuraba el paso en la aridez del desierto. El hombre medieval caminaba junto al Niño Dios envuelto en $\mathrm{Su}$ magia, creyendo, esperanzado, que al final de la travesía, el dulce consuelo de unos brazos maternales también lo ayudarían a ocupar un lugar entre los justos, a la diestra del Señor.

\section{Fuentes y Bibliografía}

\section{Fuentes}

DANTE AlighIERI, 1977, Divina Comedia, Garamond, Barcelona.

Evangelio Árabe de la Infancia, en SANTOS OTERO, Aurelio de, 2002, Los Evangelios Apócrifos, Biblioteca de Autores Cristianos, Madrid.

Evangelio Armenio de la Infancia, en SANTOS OTERO, 2002.

Evangelio de Nicodemo, en SANTOS OTERO, 2002.

Evangelio del Pseudo Mateo, en SANTOS OTERO, 2002.

GREGORIO MAGNO, SANTO, Epístola XI, 13. PL 77, $1128 \mathrm{c}$.

Historia copta de José el carpintero, en SANTOS OTERO, 2002. 
JuAn CRISÓStOMO, SANTO, Homilía XX, 3, 1991, Homilías sobre el evangelio de san Juan, Ciudad Nueva, Madrid.

Libro de Juan Arzobispo de Tesalónica, III, en SANTOS OTERO, 2002.

Protoevangelio de Santiago, en SANTOS OTERO, 2002.

Santa Biblia, 2002, Reina-Valera, Revisión 1995, Sociedad Bíblica Argentina, impreso en Brasil.

SAntos Otero, Aurelio de, 2002, Los Evangelios Apócrifos, Biblioteca de Autores Cristianos, Madrid.

SOZÓMENO, Historia Eclesiástica, V, 2, Historia Eclesiástica, texto disponible en línea: http://www.newadvent.org/fathers/26025.htm página consultada el 17/07/2009.

Vida de Adán y Eva (versión griega), en DíEZ MACHO, Alejandro, 1982, Introducción General a los Apócrifos del Antiguo Testamento, Tomo 2, Ediciones Cristiandad, Madrid.

VorAgINE, Jacobus de, 1995, The Golden Legend, Tomos I y II, Princeton University Press, Princeton.

\section{Bibliografía}

AA.VV., 1997, Romanesque, Ed. Rolf Toman, Könemann, Colonia.

AA. VV., 1997, The Glory of Byzantium, Art and Culture of the Middle Byzantine Era, A.D. 843-1261, Ed. Helen C. Evans y William D. Wixom, The Metropolitan Museum of Art, Harry N. Abrams, Nueva York.

AlBERT, Jean-Pierre, 1990, Odeurs de Sainteté, La mythologie chrétienne des aromates, Éditions de l'École des Hautes Études en Sciences Sociales, París.

ARNDT, William and GINGRICH, Wilbur, 1967, A Greek-English Lexicon of the New Testament and Other Early Christian Literature, The University of Chicago Press and Cambridge University Press.

Aubel, M..,1884, Histoire et Théorie du Symbolisme Religieux, Librairie de Féchoz et Letouzey, París, Tomo III, cap. XIII.

AVRIL, François y otros, 1982, Le monde Roman, Les temps des croisades, Gallimard, París, L’Univers des Formes.

BECKWITH, John, 1994, Early Medieval Art, Thames and Hudson, Nueva York.

BEIGBEDER, Olivier, 1995, Léxico de los símbolos, Encuentro, Madrid, 1995.

Belting, Hans, 1994, Likeness and Presence. A History of the Image before the Era of Art, The University of Chicago Press, Chicago, Londres.

Cancionero y Romancero Español, 1971, Dámaso Alonso, Salvat, Estella.

Capadocia, 1998, REVAŞ, Estambul.

CIRlot, J., Diccionario de Símbolos, 1995, Labor, Quinto Centenario, Colombia

CHAMPEAUX, Gérard de, y STERCKX, Dom Sébastien, 1992, Introducción a los símbolos, Encuentro, Madrid.

Clave Lingüística del Nuevo Testamento Griego, 1986, Isedet, La Aurora, Buenos Aires. 


\section{Patricia Grau-DieCKMAnN, Representaciones de los viajes de la Sagrada Familia}

Corpus Iuris Hibernici, 1978, ed. D. A. Binchi, vol. VI, Dublin Institute for Advanced Studies, Dublin.

Corrain, Lucia, 2002, Giotto and Medieval Art, Peter Bedrick Books. Columbus.

CroAtto, J., 2002, Experiencia de lo sagrado - Estudio de fenomenología de la religión, Verbo Divino, Villatuerta (Navarra)

DE HAMEL, Christofer, 2000, A History of Illuminated Manuscripts, Phaidon, Londres.

DíEz MACHO, 1982, Alejandro, Introducción general a los Apócrifos del Antiguo Testamento, Tomo 2, Ediciones Cristiandad, Madrid.

ECO, Umberto, 1997, Arte y belleza en la estética medieval, Lumen, Barcelona.

EDMONDS, Anna G., 1998, Turkey's Religious Sites, Damko A.S., Estambul.

FOLEY, John, 1993, The Guinness Enciclopedia of Signs \& Symbols, Guinness Publishing, Londres.

FRAZER, J., 2004, El folklore en el Antiguo Testamento, Fondo de Cultura Económica, México.

GRABAR, André, 1967, El primer arte cristiano (200-395), Aguilar, Madrid, Colección El Universo de las Formas.

Grau-DieckmanN, Patricia, 2009, "La iconografía como testimonio", Rupturas, transformações e Permanências: Sociedade e Imaginário, Universidade Estadual do Maranhão (UEMA), San Luis.

GRAU-DIECKMANN, Patricia, 2008, "Los textos apócrifos determinantes de repertorios plásticos cristianos", Del cristianismo primitivo al cristianismo medieval: temas, enfoques, problemas, Cuadernos Medievales, Facultad de Humanidades, Universidad Nacional de Mar del Plata; Universidad Nacional del Sur, Mar del Plata/Bahía Blanca. Publicado también en Acta Scientarum, 2011, Universidade Estadual de Maringá-Eduem en http://periodicos.uem.br/ojs/index.php/ActaSciEduc/article/view/14323/pdf.

Guglielmi, Nilda, 2007-2008, "Sobre la Vita de Cristina de Markyate", Temas Medievales 15-16, CONICET, IMHICIHU, DIMED, Buenos Aires.

HUBERT, Jean y otros, 1968 a, El Imperio Carolingio, Aguilar, Madrid.

HuBERT, Jean, y otros, 1968 b, La Europa de las Invasiones, Colección El Universo de las Formas, Aguilar, Madrid, . Colección Universo de las Formas

HuIZINGA, Johan, 1993, El otoño de la Edad Media, Alianza, Madrid.

Icônes grecques, melkites, russes, Col. Abu Adal, Skira, Ginebra, 1993.

KUBACH, Hans Erich, 1974, Arquitectura románica, Aguilar, Madrid.

LEVI, Eliphas, 1977, Dogma y Ritual de la Alta Magia, Kier, Buenos Aires.

Les manuscrits à peintures en France du XIIIe au XVIe siècle, 1955, Bibliothèque Nationale, Catálogo Exposición 1954, París.

LONGNON, Jean y CAZELLES, Raymond (Introducción y texto), 1989, The Très Riches Heures of Jean, Duke of Berry, George Braziller, Nueva York.

MÂLE, Emile, 1952, El arte religioso del siglos XII al siglo XVIII, Fondo de Cultura Económica, México.

MANGO, Cyril, 1975, Arquitectura Bizantina, Aguilar, Madrid. 


\section{Patricia GRAU-DiECKMANN, Representaciones de los viajes de la Sagrada Familia}

MANZI, Ofelia, 2004, "Formas de representación del poder: la influencia de Roma", Temas Medievales, 11, Buenos Aires.

MANZI, Ofelia, 1989, La influencia de la antigüedad en el arte cristiano, la "MAIESTAS", Temas de Historia del Arte Medieval, No 2/2 al 3, Facultad de Filosofía y Letras, Universidad de Buenos Aires.

MEEHAN, Bernard, 1996, The Book of Durrow. A medieval masterpiece at Trinity College Dublin, Robert Rinehart Publishers, Colorado and Town House and Country House, Dublin.

METFORD, J.C.J., 1983, Dictionary of Christian Lore and Legend, Thames and Hudson, Londres.

MEYENDORF, John, 2002, Teología Bizantina, Ed. Cristiandad, Madrid.

Miguel PSEllos, 1838, Homilía a sus discípulos negligentes, ed. J. F.

Boissonade, Nürnberg; Amsterdam, 1964. En MEYENDORF, 2002.

MilaneSI, G., 1854, Documenti per la storia dell'Arte sienese, Vol I, Siena, 1854. En Teorías y Realizaciones del Arte Medieval, 1977, selección, traducción y prólogo Manzi, O. y Corti, F., Tekné, Buenos Aires.

QUENOT, Michel,1990, El Icono, Desclée De Brouwer, Bilbao.

RANKE-HeInEMANN, Uta, 1995, Putting away childish things, Harper, San Francisco.

RÉAU, Louis, 1996, Iconografía del Arte Cristiano, Tomo 1, vol. 1: Iconografía de la Biblia - Antiguo Testamento, Ediciones del Serbal, Barcelona.

RÉAU, Louis, Iconografía del Arte Cristiano, Tomo 1, vol. 2: Iconografía de la Biblia - Nuevo Testamento, Ediciones del Serbal, Barcelona, 1996.

RÉAU, Louis, 1996, Iconografía del Arte Cristiano, Tomo 2, Vol. 4, Iconografía de los santos, Ediciones del Serbal, Barcelona.

RÉAU, Louis, 1996, Iconografía del Arte Cristiano, Tomo 2, Vol. 5, Iconografía de los santos, Ediciones del Serbal, Barcelona.

RÉAU, Louis, 1946, L'art religieux du Moyen Age (La sculpture), Fernand Nathan, París.

Romances, coplas y canciones, 1981, Centro Editor de América Latina, Buenos Aires.

SCHAPIRO, Meyer, 1987, Estudios sobre el arte de la Antigüedad tardía, el Cristianismo primitivo y la Edad Media, Alianza Editorial, Madrid.

SCHAPIRO, Meyer, 1984, Estudios sobre el románico, Alianza Editorial, Madrid.

SILL, Gertrude Grace,1975, A handbook of Symbols in Christian Art, Collier Books, Macmillan Publishing Co., Nueva York.

SIMONS, Gerald, 1966, Barbarian Europe, Time-Life Books, Alexandria, 1966.

SOZÓMENO, Historia Eclesiástica, texto disponible en línea: http://www.newadvent.org/fathers/26025.htm página consultada el 17/07/09.

Sutton Hoo Ship Burial: The Original Helmet (side view), en http://www.archeurope.com/index.php?page=sutton-hoo-ship-burial-the-originalhelmet-side-view, página consultada el 30/11/2012.

SwAAM, Wim, 1984, The Gothic Cathedral, Omega Books, Londres. 
Teorías y Realizaciones del Arte Medieval, 1977, selección, traducción y prólogo MANZI, O. y CORTI, F., Tekné, Buenos Aires.

The English and Scottish Popular Ballads, 1970, editada por Francis James Child bajo el $\mathrm{N}^{\mathrm{o}} 54$ A y recopilada por The Norton Anthology of Poetry, W. W. Norton, Nueva York.

THENAUD, J., 1884, Le voyage d'outremer (Egypte, Mont Sinaï, Palestine) de Jean Thenaud, gardien du couvent des cordeliers d'Angoulème, suivi de La relation de l'ambassade de Domenico Trevisan auprès du Soudan d'Egypte, éd. et trad. Ch. Schefer, París, E. Leroux. En ALBERT, 1990.

The Norton Anthology of Poetry,1970, W. W. Norton, Nueva York.

TOLLEY, T, 1993, Libro de Horas, Libsa, Madrid.

The St. Albans' Psalter, University of Aberdeen, http://www.abdn.ac.uk/stalbanspsalter, página consultada el 21/08/2009.

WALTHER, Ingo., WOLF, Norbert, 2005, Los manuscritos iluminados más bellos del mundo, desde 400 hasta 1600, Taschen, Colonia. 